Florida International University FIU Digital Commons

3-30-2004

\title{
El discurso vindicatorio de Juan Goytisolo y Zoé Valdéz : deconstrucción y recodificación del lenguaje hegemónico
}

Barbara Cabana

Florida International University

DOI: $10.25148 /$ etd.FI14052515

Follow this and additional works at: https://digitalcommons.fiu.edu/etd

Part of the Spanish Linguistics Commons, and the Spanish Literature Commons

\section{Recommended Citation}

Cabana, Barbara, "El discurso vindicatorio de Juan Goytisolo y Zoé Valdéz : deconstrucción y recodificación del lenguaje hegemónico" (2004). FIU Electronic Theses and Dissertations. 1952.

https://digitalcommons.fiu.edu/etd/1952 
Miami, Florida

EL DISCURSO VINDICATORIO DE JUAN GOYTISOLO Y ZOÉ VALDÉS: DECONSTRUCCIÓN Y RECODIFICACIÓN DEL LENGUAJE HEGEMÓNICO

A dissertation submitted in partial fulfillment of the requirements for the degree of

DOCTOR OF PHILOSOPHY

in

SPANISH

by

Barbara Cabana

2004 
To: Dean R. Bruce Dunlap

College of Arts and Sciences

This dissertation, written by Barbara Cabana, and entitled El discurso vindicatorio de Juan Goytisolo y Zoé Valdés: Deconstrucción y recodificación del lenguaje hegemónico, having been approved in respect to style and intellectual content, is referred to you for judgment.

We have read this dissertation and recommend that it be approved.

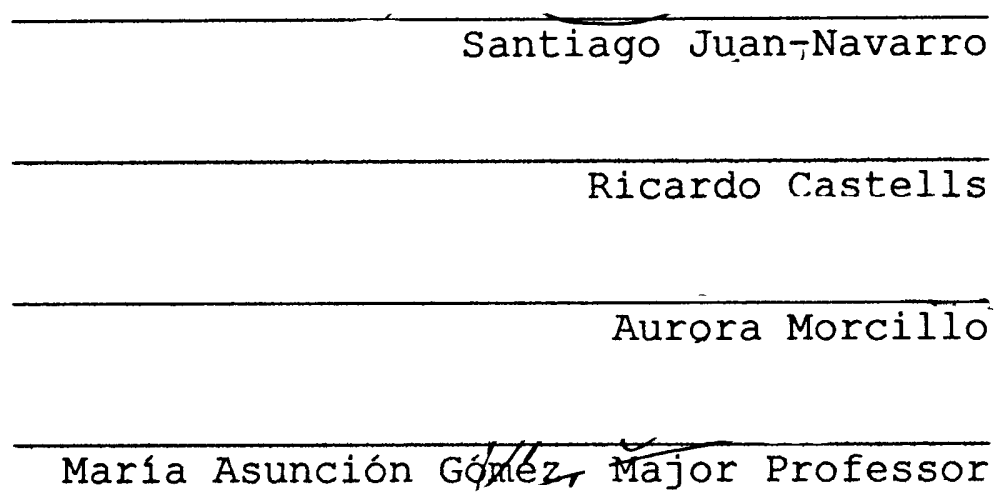

Date of Defense: March 30, 2004

The dissertation of Barbara Cabana is approved.

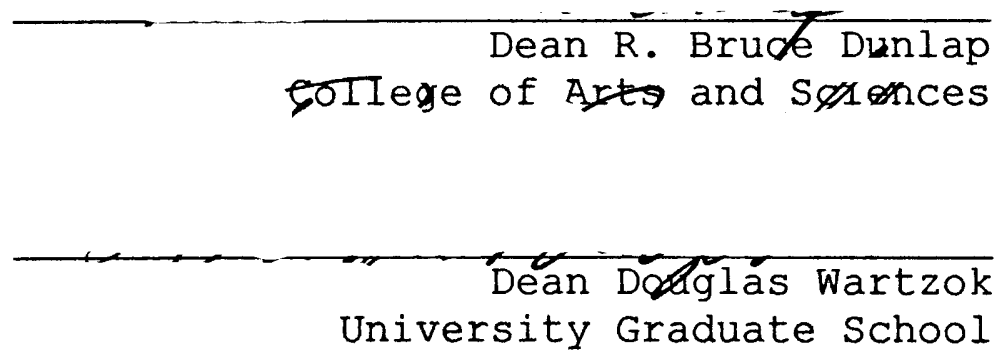

Florida International University, 2004 
(C) Copyright 2004 by Barbara Cabana

All rights reserved. 


\section{DEDICATORIA}

Dedico esta tesis a Ramiro y a Viviana y, especialmente, a mi abuela por haber sufrido estoicamente "el período especial". 


\section{AGRADECIMIENTOS}

Primeramente, quisiera expresar mi gratitud a la directora de esta tesis, la profesora Asunción Gómez por su apoyo académico, su dedicación y estímulo a lo largo de la elaboración de este trabajo. Igualmente, deseo mencionar mi agradecimiento a Reinaldo Sánchez por su inspiración; a los profesores Ricardo Castells, Santiago Juan-Navarro y Aurora Morcillo por su colaboración, así como al Departamento de Modern Languages y al University Graduate School de Florida International University, por otorgarme el Dissertation Year Fellowship. Mi agradecimiento también va dirigido hacia la escritora Zoé Valdés por la entrevista que me concedió para este estudio, y a Enaida M. Unzueta que la facilitó. De igual modo, deseo reconocer la cooperación del departamento de Interlibrary Loans \& Documents de Green Library por su eficaz trabajo en facilitarme los numerosos artículos y libros consultados para esta tesis. 
EL DISCURSO VINDICATORIO DE JUAN GOYTISOLO Y ZOÉ VALDÉS: DECONSTRUCCIÓN Y RECODIFICACIÓN DEL LENGUAJE HEGEMÓNICO by

\section{Barbara Cabana}

Florida International University, 2004

$$
\text { Miami, Elorida }
$$

María Asunción Gómez, Major Professor

The goal of this dissertation is to explore the use of transgressive language in the works of Juan Goytisolo and Zoé Valdés. This study examines the socio-political and cultural contexts in which the narrative of both authors develops, as well as the textual devices employed by these writers for undermining the "official history" imposed by the dictatorial regimes in Francoist Spain and Castro's Cuba. Furthermore, this dissertation argues that the deconstructing strategies in Goytisolo and Valdés mark their literary trajectory. Their vindicatory standpoints seek an alternative discourse of national identity.

The function of language in demythifying and recodifying hegemonic discourse is examined in Goytisolo's trilogy Señas de identidad, Reivindicación del conde don Julián, and Juan sin tierra; and the novels of Zoé Valdés La nada cotidiana and Te di la vida entera. The parallelisms 
in the literary works of Goytisolo and Valdés are established by contrasting the authors' revisionist approach to history, the self-reflexivity of their novels, the sexual referent, and the use of irony and parody. The theoretical framework incorporates poststructuralist theorists such as Todorov, Foucault, Lacan, Barthes, Derrida, and Kristeva; the psychoanalytical theory of Freud; and the feminist theories of Cixous and Irigaray. The comparative approach of this study and the interplay of power, politics, aesthetic creation, and author's psychology provide an illuminating perspective that could be of interest to individuals from a variety of disciplines. 
I. ANTECEDENTES HISTÓRICOS DE LA REPRESIÓN Y SU PROYECCIÓN EN EL ÁMBITO LITERARIO

II. LA CONSTRUCCIÓN Y DECONSTRUCCIÓN DEL

III. EL DISCURSO DISIDENTE Y VINDICATIVO EN ZOÉ VALDÉS

IV. LA AGRESIÓN DISCURSIVA Y VINDICATORIA EN JUAN GOYTISOLO

CONCLUSIONES

BIBLIOGRAFÍA 


\section{INTRODUCCIÓN}

Este estudio tiene como objetivo plantear la función subversiva de la escritura como una versión contestataria al discurso oficial que sustentan los mitos en los regímenes censurantes. A partir de esta premisa se intenta demostrar el enfrentamiento entre la creación literaria y los discursos hegemónicos y su representación en la novelística de Juan Goytisolo y Zoé Valdés. En sus obras encontramos la deconstrucción y recodificación del planteamiento oficialista por medio de transgresiones ideológicas y estéticas que desenmascaran la mitología establecida, tanto por la dictadura franquista de la España de la posguerra como por el actual régimen castrista en Cuba. A pesar de que los novelistas seleccionados provienen de dos espacios geográficos divergentes, existen ciertos paralelismos que se repiten en los contextos sociohistóricos y culturales en que se desarrollan y que influyen en la narrativa de ambos. Goytisolo y Valdés trascienden las circunstancias históricas concretas y se enmarcan dentro de una problemática más amplia: la escritura contra las estructuras del poder.

Para identificar los rasgos generales y los componentes caracterizadores del discurso desmitificador que comparten ambos autores, se realiza un análisis 
lingüístico y literario enmarcado en la trilogía goytisoliana--Señas de identidad, Reivindicación del conde Don Julián y Juan sin tierra--y de las novelas de Zoé Valdés--La nada cotidiana y Te di la vida entera. Para ello se aplican tanto los referentes teóricos de Bajtín como los planteados por postestructuralistas como Julia Kristeva, Jacques Lacan, Roland Barthes y Derrida, que analizan los aspectos lingüísticos de la escritura. Igualmente, se utilizan los postulados de Michael Foucault y Sigmund Freud para acercarnos a los conceptos psicoanalíticos relacionados al acto vindicatorio y la configuración de las estructuras del poder. Además, nuestro análisis se apoya en la amplia producción ensayística de Goytisolo, quien, preocupado por teorizar su visión de la literatura, señala la concordancia entre sus postulados y su práctica literaria. En el caso de Valdés, acudimos a la teoría feminista y a entrevistas donde la escritora aporta datos para la interpretación de su producción literaria.

Al precisar las coincidencias entre ambos narradores en el proceso de recodificación del discurso censurante y autoritario para configurar un nuevo discurso vindicatorio, se observan ciertas características posmodernas en ambos escritores tales como la desacralización, la 
intertextualidad, la autorreferencialidad y la novela como parodia abierta. De igual forma se ejemplifican aquellos rasgos en que difieren el enfoque de Goytisolo y el de Valdés, explicando tanto los condicionamientos personales como los de índole estética.

Esta tesis se centra en tres puntos de contacto que engarzan las obras de Goytisolo y Valdés:

1) Sexualidad y escritura: Para estos escritores la afirmación de la sexualidad es un arma hábilmente utilizada para impugnar y desmitificar la dominación hegemónica. Ambos autores enlazan el texto literario a una vivencia de la corporalidad, imbricando de esta forma la sexualidad al discurso de la nación. En la narrativa goytisoliana la representación del cuerpo está marcada por la mirada masculina del protagonista. Goytisolo interpreta sus propios espacios eróticos con clara resonancia homosexual, conectando los espacios femeninos con la castidad y represión impuesta por el catolicismo nacional. Valdés hace de lo corporal femenino un contradiscurso liberador frente al masculino/patriarcal, subvirtiendo los estereotipos de pasividad atribuidos a la mujer.

\section{2) Las vindicaciones personales a través del lenguaje}

trasgresor: Ambos escritores utilizan la palabra escrita como arma desestabilizadora para impugnar los sistemas 
políticos a los que pertenecen. Goytisolo lo logra a través de una ruptura con el lenguaje purista y la parodia de las obras canónicas de la literatura castellana, en un intento desmitificador de la versión generalizada que se ha mantenido como representativa o definidora de la esencia española. En la escritura valdesiana, se socava el registro lingüístico estándar del discurso y consignas oficialistas con un léxico subestándar recogido del argot callejero, negándole al orden establecido el léxico que éste quisiera, sustituyéndolo por el choteo y la parodia lingüística. Además, ambos escritores convierten el espacio discursivo en un campo de batalla donde dirimir no sólo sus conflictos personales con el Poder, sino también donde expresar un exorcismo vindicatorio.

\section{3) La continuidad a nivel de personajes: Las}

narraciones de Goytisolo y Valdés tienden a presentar en sus narraciones unos personajes recurrentes en los que se reflejan facetas de la personalidad del autor. En Valdés las protagonistas de las dos novelas tienen rasgos psicológicos y sociales similares. Yocandra y Cuca son personajes alegóricos que encarnan las vicisitudes y opresión de la nación cubana, representan una definición del mundo referencial de la Isla. En Goytisolo, se reiteran en las tres novelas las mismas características en el personaje proteico de Álvaro Mendiola, alter ego del 
escritor. A través de la trilogía, Mendiola se presenta con la misma problemática psicológica, existencial e histórica. El protagonista de Señas de identidad se metamorfosea en La reivindación del conde don Julián, introduciéndose en la piel del legendario traidor y otros personajes, apareciendo y desapareciendo de nuevo en Juan sin tierra en función de las necesidades del texto.

Los tres temas mencionados están desarrollados a lo largo de cuatro capítulos. El primero establece algunas consideraciones generales sobre la censura dentro de los regímenes represivos, como también sus efectos sobre el individuo y sobre las diferentes formas de expresión cultural. El enfoque se centra en la novelística de posguerra española y la narrativa cubana del "período especial". Dentro de esos contextos se estudia, con intención ubicadora, la genealogía de la represión, no estrictamente desde la perspectiva de su semántica original, sino del modo en que se revela como elemento catalizador en la escritura y se convierte en instrumento de reflexión y crítica contra las estrategias del poder.

Partimos de los postulados de Frederic Jameson sobre el "inconsciente político" que establece que todo escritor se debe a su sociedad, a su tiempo, y es por naturaleza un ser dialéctico, político y social. De igual modo se 
utilizan los estudios de Michel Foucault para analizar la influencia de los discursos teológicos sobre la epistemología del poder. Además, se estudian el contexto cubano posrevolucionario y el español de la posguerra y se comparan los resortes utilizados en ambos sistemas para implantar la mitificación de ambos regímenes y para establecer sus métodos censurantes. Se analizan la Revolución cubana y el franquismo a través del pensamiento foucaultiano planteado en La voluntad de saber y La vida de Ios hombres infames.

Argumentamos que la represión en España se remonta a la época de la Reconquista donde se confunde la identidad católica con la identidad nacional, y que esta noción de que la ética de la sociedad española es de raíz cristiana se proyecta durante la dictadura franquista. De igual modo se plantea, que la mitología revolucionaria cubana creó su propia modificación del ideal ascético, autodefiniéndose como una revolución mesiánica con vestigios del poder pastoral definido por Foucault. Por tanto, planteamos que la Revolución Cubana, a pesar de que sostiene un discurso que es ideológicamente de índole marxista, converge y es de la misma estirpe del poder falangista, en cuanto a los hábitos mentales de sumisión al poder y la aceptación acrítica a los valores oficiales. 
En el segundo capítulo se revisan detalladamente los postulados teóricos de Mijail Bajtín en su dimensión antropológica y social, vinculando el concepto de carnavalización con la narrativa de los escritores en cuestión. Tomamos del teórico ruso la idea de que todo lo que el hombre hace en la cultura se traduce en una esfera del lenguaje, y el modo en que el lenguaje desorganiza la autoridad y libera voces alternativas. Los textos postestructuralistas de Derrida, Roland Barthes, Kristeva y Lacan se relacionan con la función del lenguaje en la deconstrucción y recodificación del discurso literario. Se destaca el protagonismo del lenguaje en las novelas de Goytisolo y Valdés como vehículo desestabilizador, analizando la forma en que los autores en cuestión subvierten la palabra monopolizada por el discurso oficial implantando un quebrantamiento a nivel lingüístico.

El tercer capítulo analiza los elementos vindicadores y transgresores de la escritura valdesiana en el contexto del "período especial" y la literatura del "boom cubano" de los noventa. Se subraya el fuerte contenido socio-político y la perspectiva erótico-feminista en las novelas La nada cotidiana y Te di la vida entera utilizando el marco teórico de la crítica feminista de Cixous, Irigaray y Nelly Richards. Se enfatiza la utilización por parte de la 
escritora del código lingüístico subestándar en su prosa cruda y visceral, que no abandona el choteo y la irreverencia para transgredir los paradigmas de la ideología masculina. De igual modo, se observan cómo las características estilísticas de Valdés contradicen el concepto ampliamente aceptado de que esa acérrima violencia textual sólo se manifiesta predominantemente en escritores del sexo masculino. Se denuncia el binomio de lo masculino en oposición de lo femenino, siendo tradicionalmente el primer elemento el dominante, proviniendo la amenaza, en este caso, del signo mujer. Esta subversión de los géneros a través de la sexualidad es especialmente notable en un régimen totalitario que está constituido ante todo por un mundo viril, centrado en un paradigma masculino por decreto.

El cuarto capítulo estudia la fusión del narrador y autor en la trilogía "España sagrada" o "Del desarraigo y de la ruptura": Señas de identidad, Reivindicación del conde don Julián y Juan sin tierra. El enfoque se dirige a la manifestación de la represión y al deseo imprescindible de purgarse de ella mediante la palabra escrita. También se analiza la violencia discursiva y la libidinosa brutalidad utilizada por Goytisolo en Reivindicación del conde don Julián para agredir los valores y mitos que 
sustentan el discurso hegemónico, proporcionando una dimensión psicológica a la represión y la violencia.

Los escritores analizados en esta tesis han construido su corpus novelístico influidos por dos sistemas dictatoriales que comparten rasgos similares aunque parezcan a simple vista de ideología totalmente opuesta. Juan Goytisolo y Zoé Valdés, por distintas vías y procedimientos escriturales, se acercan desde su creación estética a unas realidades opresoras vividas por ellos en distintas épocas y circunstancias sociales, con un afán común de reivindicar las voces silenciadas por regímenes totalitarios. Ambos autores han reinterpretado y reconstruido las identidades de sus protagonistas sobre en función del cumplimiento de un deber vinculado al desarrollo personal y nacional. Goytisolo y Valdés componen sus novelas con elementos autobiográficos que aluden a hechos del contexto social que les ha tocado vivir. Ambos denuncian los sistemas que impiden el pleno desarrollo intelectual y psicológico del ser humano. En este sentido, el acercamiento de esta tesis a la interacción existente entre las estructuras del poder, la politica, la psicología individual y la creación estética aporta una nueva dimensión de la obra literaria. 


\title{
CAPITULO I
}

\section{ANTECEDENTES HISTÓRICOS DE IA REPRESIÓN Y SU}

\section{PROYECCIÓN EN EL ÁMBITO IITERARIO.}

\author{
"...solas dos fuerzas pueden \\ contener los deberes sociales: la \\ represión interior religiosa y la \\ exterior política, o, según una \\ frase célebre, la religión o la \\ metralla". \\ La unidad católica. \\ Madrid, 1876 \\ "Aquello que te censuren, cultívalo \\ porque eso serás tú". \\ Juan Goytisolo
}

Este capítulo establecerá algunas consideraciones generales sobre los antecedentes de la censura y otros aspectos de la represión, relacionados con sus efectos sobre las diferentes formas de expresión cultural. Estas ideas se conectarán con nuevas adaptaciones dentro de la obra literaria, con la intención de relacionarlas críticamente con los textos de Juan Goytisolo y Zoé Valdés. Dedicamos especial atención al tema de la represión, no estrictamente desde la perspectiva de su semántica original, sino estudiamos el modo en que se revela como elemento catalizador en la escritura y se convierte en instrumento de reflexión y crítica contra las estrategias del discurso hegemónico.

Nuestro objetivo es resaltar el modo en que el texto literario emerge del contexto que lo genera, conllevando 
intrínsicamente los componentes socio-politicos y económicos y por ende, su subtexto. Partimos de los postulados de Jameson, quien asevera que existen dos horizontes en el texto, el horizonte politico y el social, siendo precisamente este último donde se reescribe la pugna ideológica entre discursos sociales enfrentados por el poder:

The compartmentalization and specialization of the various regions of social life [. . .] is at least locally overcome, on the occasion of a particular analysis. Such momentary reunification would remain purely symbolic, a mere methodological were it not understood that social life is in its fundamental reality one and indivisible, a seamless web, a single inconceivable and transindividual process, in which there is no need to invent ways of linking language events and social upheavals or economic contradictions because on that level they were never separate from one another. (40)

Por lo tanto, no hay obra que exista en el vacío o carezca de contexto. Autores y textos están destinados a convertirse, por regla general, en los representantes de una generación, de un período histórico, de una nación. Históricamente 
situado, el escritor se debe a su sociedad, a su tiempo. ${ }^{1}$ Estas reflexiones nos ayudarán a comprender la situación de los creadores, que condenados bajo dictaduras, asumen el papel de disidentes intelectuales. ${ }^{2}$

La ubicación de las obras disidentes en cuestión, respecto al concepto de autoridad y de su correlato literario es, precisamente, lo que intentamos dilucidar en este capítulo. Para ello es preciso establecer como marco referencial, dentro de la contextualización histórica, la diferencia entre ideología, autoritarismo y dictadura, como también la interacción de éstos en los sistemas totalitarios. La ideología es analizada desde su principal característica definitoria: la devoción casi religiosa de seguidores específicos hacia unas nociones políticas que consideran absolutamente incompatibles con las de otros sistemas. Este rasgo se evidencia en dos poderosas ideologías de captación: el comunismo y el fascismo. Para los fines de nuestro estudio, focalizamos el aspecto de adoctrinación impuesto a través del sistema de educación y movilización de las masas. El autoritarismo es enfocado desde la perspectiva de ente restrictivo de las actividades sociales, intelectuales y culturales. De igual modo, se analiza cómo este sistema de gobierno ejerce una supremacía sobre el individuo, siendo una autocracia que profesa un monopolio de los medios 
de comunicación, especialmente la actividad creadora, la cual se halla supeditada a los fines de los dirigentes y de la ideología inspiradora del Estado. La dictadura se estudia como forma de gobierno con aspiraciones hegemónicas y programas autoritarios, implicando la restricción o supresión de las libertades de expresión. Sobre todo, el poder dictatorial ejercido por un ser ubicuo, al margen o por encima de las leyes, sin sometimiento o fiscalización alguna.

Enmarcamos las obras de esta tesis dentro de la novelística española de posguerra y la narrativa cubana del "período especial" y examinamos asimismo el desarrollo de una condición histórica heredada, de la cual son deudores, tanto España, como los pueblos hispanoamericanos. ${ }^{3}$ Los orígenes de dicha condición se remontan a la época de la Reconquista que confundió la identidad católica con la identidad nacional y, sobre todo, de la Inquisición, durante la Contrarreforma, que tuvo como consecuencia una compenetración de la Iglesia y el Estado. Tal como sostiene Guy Hermet, "de ce moment datent, en Espagne, le rôle moderne de l'Eglise comme agent idéologique primordial, et celui de 1'Inquisition comme première bureaucratie 'totalitaire' "(12). Por lo tanto, desde el principio se sientan las bases necesarias para que el imperio 
eclesiástico creyera que su verdad no sólo era suya, sino que era la verdad absoluta. Esa pretensión de posesión de la verdad se convirtió en la premisa básica sobre la que gravitó el discurso ideológico de la Iglesia el cual implantó una educación represora, culpabilizadora y maniquea. Desde esta postura defensiva el catolicismo creó un movimiento de carácter paternalista, que definiría profundamente el devenir histórico y establecería las características de los regímenes autoritarios y de las dictaduras militares implantadas en España y en Latinoamérica, marcando la psiquis nacional de tal forma, que los resultados están vigentes aún hoy en día.

Sin embargo, el punto importante a resaltar de este patrón social, político y religioso, es su repercusión en el ámbito intelectual, lo cual se evidencia en la literatura desde muy temprano. Desde los lejanos tiempos en que inquisidores como fray Tomás de Torquemada enviaban a la hoguera a todos los sospechosos de herejía, tanto los más grandes como los más insignificantes escritores españoles estuvieron expuestos a que les hicieran correcciones en los textos de sus obras. Santa Teresa de Ávila, cuya autobiografía fue denunciada a la Inquisición en 1565 y cuyas obras fueron tachadas de supersticiosas, fue sometida a los juicios del Santo Oficio. Igualmente se 
puede decir de fray Luis de León, San Juan de la Cruz, Quevedo y Larra, por mencionar sólo algunos. ${ }^{4}$

La mentalidad cristiana establecida en España fue trasladada a Hispanoamérica con todas sus consecuencias políticas y psicológicas; el pensamiento teológico inspiró el pensamiento político. De ahí que la historia de América Latina sea un reincidir en la idea de una condición paradisíaca, y que la cultura hispanoamericana haya estado por siglos alimentada de la utopía de crear al "hombre nuevo", o insistiendo en ver el carácter "deformante" de las Ilamadas "Edades de Oro" y "El Dorado". Lo cierto es que la Conquista no fue sólo una empresa de codicia, sino de la imposición del poder y del sometimiento espiritual. ${ }^{5}$ Esas luchas del poder establecidas durante la colonización de América son descritas con gran precisión por Mariano Picón Salas:

Más que el interés espiritual de evangelizar a los indios, prevalece ahora el de dominar en la sociedad criolla. Por esa preeminencia luchan franciscanos contra dominicos y dominicos contra jesuitas en las universidades coloniales; frailes contra clero secular en los obispados, y en general la iglesia contra el poder civil, a 
través de las más mínimas querellas de etiqueta o jurisdicción. (109)

La España teocrática y autoritaria que colonizó América, comprometida con la Contrarreforma, quebrantó siempre la iniciativa individual con toda forma de reglamentaciones. El Nuevo Mundo se convirtió en la permutación territorial de habitantes del viejo, lo que posibilitó que la represión intelectual se impusiera desde sus inicios. La prohibición a la entrada de libros procedentes de Europa fue radical en los virreinatos de México y Perú debido a que El Santo Oficio estableció que los textos no religiosos mentían siempre por ofrecer una visión falaz de la vida. En palabras de Vargas Llosa: Los inquisidores españoles prohibieron que se publicaran o importaran novelas en las colonias hispanoamericanas con el argumento de que esos libros disparatados y absurdos--es decir, mentirosos--podían ser perjudiciales para la salud espiritual de los indios. Por esta razón, los hispanoamericanos sólo leyeron ficciones de contrabando durante trescientos años y la primera novela que, con tal nombre, se publicó en la América española apareció sólo después de la independencia [en México, en 1816].(5) 
Sin embargo, a pesar de la posición paternalista del estado y la función fiscalizadora de la Iglesia, el intelecto colonial, a quien no se le permitía escribir novelas ni historias sobre los indígenas, se rebelaría con textos como El carnero de Juan Rodríguez Freile, y en autores como Juan Caviedes o Sor Juana Inés de la Cruz en México. No es necesario mencionar la harta conocida lista de tantos otros textos subversivos que han sido objeto del ostracismo en la América española, para precisar cómo el ejercicio inquisitorial del poder--cuyo principal objetivo ha sido la exclusión de lo otro, lo diferente--surge a raíz de aquella empresa única de la Conquista. Esa necesidad de dominar, obtener poder y de evangelizar compulsivamente al mismo tiempo, engendró una situación no sólo contradictoria, sino irreconciliable, pero que paradójicamente, definiría significativamente todo el acervo literario futuro, tanto de España como Hispanoamérica.

Los planteamientos foucaultianos sobre la configuración de los discursos políticos y sociales, son útiles para analizar los efectos del ascetismo cristiano, tan históricamente influyente en España e Hispanoamérica a lo largo de la historia. Eoucault sugiere que las luces de la modernidad tienen también, en su genealogía, la organización religiosa de la vida en el occidente 
cristiano. En su obra la voluntad de saber, hay indicios suficientes para situar en la ascética del cristianismo primitivo, todo ese conjunto de instrumentos de guía espiritual que pretendían inculcar una obediencia incondicional conduciendo al creyente por el camino de la salvación. Foucault plantea el tema por medio de la siguiente pregunta: "¿La prohibición, la censura, la denegación son las formas según las cuales el poder se ejerce de un modo general en toda sociedad?" (17). Sobre ese comienzo de una edad de represión, el teórico afirma en La vida de los hombres infames:

Todas estas técnicas cristianas del examen, la confesión, la dirección de conciencia y la obediencia tienen como finalidad conducir a los individuos a que contribuyan a su propia mortificación en este mundo. La mortificación no es la muerte, sin duda, sino que es la renuncia a este mundo y a uno mismo: una especie de muerte cotidiana. (284)

Vemos así cómo la búsqueda de castidad implica una actitud de renuncia al mundo según una técnica de análisis y diagnóstico de uno mismo que se verbaliza en la confesión haciendo patente la culpa. A través de la confesión, cada sujeto está dirigido por el imperativo moral de averiguar 
quién es, qué ocurre en su interior, cuáles son sus tentaciones. La confesión descubre los peligros de los pensamientos impuros, objetiva al sujeto, pero sólo lo hace gracias a la participación de los otros; por la verbalización de uno ante los demás se desentrañan todos los pensamientos que conducen al pecado. De esta manera, el que escucha en la confesión no será sólo dueño del perdón, el juez que condena o absuelve, sino que será el dueño de la verdad porque su función es hermenéutica. Al igual que Nietzsche, quien ya había señalado cómo el aparato cristiano de autocastigo se había transformado y secularizado dentro de la organización de las sociedades modernas, la reproblematización de la temática del poder foucaultiana surge de la revalorización de esos terrenos religiosos. En sus escritos se percibe la exigencia de indagar la manera en que se había producido esa "gubernamentalización" de las técnicas del poder para poner en evidencia el desplazamiento del modelo ascético del "pastor" y del "rebaño", y contrastar esta metáfora con el modelo del poder político. El "poder pastoral" no se realiza por la aplicación idealmente automática de un conjunto de normas; al contrario, se trata de que cada persona sobre la cual se ejerce el poder (las ovejas del 
rebaño) sea permanentemente fiscalizada y protegida. Tal como asevera Pablo López Alvarez:

Por eso, cuando Foucault, interesado en reconocer los elementos "teológicos" todavía persistentes en nuestros valores, en su escrito "El sujeto $y$ el poder" en Más allá del estructuralismo y la hermenéutica, distingue entre la institucionalización eclesiástica del poder pastoral y la "función" de dicha institucionalización fuera del estricto ámbito institucional, puede decirse que está de alguna manera recogiendo y "actualizando" ese mismo interés que ya adelantara Nietzsche en Zur Genealogie der Moral: poner de manifiesto la tremenda importancia e influencia que este "poder pastoral" (la persistencia de los "ideales ascéticos") todavía posee como tipo de poder "individualizante" y, a la vez, "totalizador". (305)

Es notable que el interés de Foucault por los discursos teológicos influya sobre la epistemología del poder, y lo convierta en un arqueólogo y genealogista que dirige su análisis al proceso de formación de los discursos y al esclarecimiento de su función política. De este modo, 
el teórico francés nos ilumina sobre la manera en que los regímenes y las instituciones establecidas por ellos operan como generadores del control social. En efecto, en el discurso ideológico franquista, al igual que la versión análoga en el ámbito discursivo de la revolución cubana, se encuentran los residuos de una concepción "pastoral" acomodada a nuevas condiciones discursivas orientadas a un predominio del poder político. Estas semejanzas son evidentes cuando se comparan entre sí los métodos represivos utilizados por ambos sistemas.

Durante los casi cuarenta años de dictadura franquista, el catolicismo constituyó el componente inherente del substrato ideológico y la bandera legitimadora del régimen, haciéndolo distinto a otros regímenes totalitarios en Europa porque como reconoce Guy Hermet: "l'Eglise d'Espagne s'cest oppossé plus que la plupart des autres Eglises européennes aux implications politiques du libéralisme dominant dont elle n'acceptait d'ailleurs pas sans réticence les dimensions économiques" (16) .

Aunque el liberalismo en sus detalles seguía siendo combatido por la Iglesia, la misma había acabado por asimilar las formulaciones económicas del pensamiento liberal a lo largo del siglo XIX. Sin embargo, no sucede 
Hay que destacar asimismo, el epistolario de Américo Castro durante el franquismo, el cual refleja una profunda preocupación por la historia y el futuro de su país, tema fundamental sobre el que gira toda su obra (y a la que el estudioso dedicó numerosas páginas a lo largo de su vida) . ${ }^{6}$ Desde su exilio, este intelectual se compadece de un país que aspiraba a reencarnarse en sus peores años: aquella España inquisitorial, imperial y mesiánica donde la tolerancia ideológica y la convivencia entre los individuos no eran posibles. Y sobre todo, lamenta que su pueblo fuera incapaz de sacudirse las taras de su historia, "del esnobismo patriotero y nacionalismo cerrado" que tanto atacará Goytisolo en su novelística.

Es interesante resaltar la reflexión histórica de Américo Castro sobre su país al comparar los métodos represivos utilizados por el régimen franquista con los de gobiernos de ideología marxista. ${ }^{7}$ El historiador advierte que la solución para España no es pasar de un régimen fascista a otro marxista, como algunos intelectuales españoles habían defendido en la década de los sesenta, donde "del mito alucinante del 'imperio', pasan al mesianismo marxista con gran facilidad. Anhelando 'mensajes' de cualquier más allá, dan con el pie a cualquier proyecto de plantar y cultivar" (72). Su epistolario refleja una 
posición política claramente alejada de todo extremismo que tiranice al individuo y que no le permita expresarse con libertad. Según Américo Castro, la solución para España radicaba en eliminar la repetición de su propio pasado, erradicar un mal congénito que había sido fomentado durante siglos.

En este trabajo analizamos las confluencias existentes entre dos regímenes totalitarios, aun cuando éstos parezcan a simple vista totalmente disímiles. A pesar de que los regímenes fascistas hacen hincapié en el nacionalismo, éstos se parecen a menudo a las dictaduras y tiranías autoritarias, exhibiendo características del totalitarismo existente en los sistemas comunistas. La imbricación entre el totalitarismo y el fascismo es analizada por Stanley G. Payne, quien señala:

During the final thaw in the Soviet bloc in 1980s, scholars in Communist lands who analyzed the central European fascist regimes were increasingly impressed by the similarity of the authoritarian institutions under fascism to those in the Soviet bloc. (449)

Payne, en su interpretación del fascismo, estudia también las personalidades autoritarias en dichos regímenes, señalando que "one empirical study not surprisingly found 
Communist personalities as 'authoritarian' as those of fascists" (454). Esta afirmación concuerda con la admiración que Fidel Castro sintió durante su formación intelectual por ciertas figuras políticas, y en especial por aquéllas de corte fascista. Según afirma Mario Llerena: El joven Castro era devoto admirador de Lenin, Hitler, Mussolini, Perón, José Antonio Primo de Rivera. Como ávido lector que era, entre sus libros preferidos estaba Mi lucha por Hitler y Lo que hay que hacer de Lenin: Pero su favorito por entonces era José Antonio Primo de Rivera, el joven fundador del movimiento fascista Falange Española, cuyos discursos se dice Castro sabía de memoria. (219) [..] No existe absolutamente la menor duda de que, de haber llegado al poder 30 años antes, su decisión segura habría sido la nazificación de Cuba. Pero el nazismo no logró convertirise en super portencia y Hitler estaba muerto. De modo que quedaba una sola puerta totalitaria abierta para Castro, la del comunismo. (227)

A este efecto, puede establecerse un paralelo entre los mitos fundadores de España, y por extensión la dictadura franquista, y aquellos sobre los que se adscribe 
la Revolución Cubana en su acción totalizante y efecto paralizante. Desde sus inicios, el régimen castrista adoptó la ideología marxista con un fervor casi religioso, como una especie de misión apostólica, estableciendo una devoción revolucionaria fanática que entregaba su corazón en cada rincón de la cultura donde el coro entonaba sus alabanzas. El código moral de la conciencia revolucionaria se convirtió en una especie de catecismo, con respuestas prefabricadas para todos los problemas, eximiendo al individuo de pensar, de cuestionar el entorno y cuestionarse a sí mismo. En dicho sistema se trató de acabar con los seres humanos capaces de opinar y de disentir, para así tiranizarlos sin obstáculo y someterlos totalmente a las directivas del poder. Es de notar que, a pesar de que el discurso que sostiene ideológicamente a la Revolución es de índole marxista, gran parte de esta revolución converge con el falangismo en cuanto a los hábitos mentales de sumisión al poder y la aceptación acrítica de los valores oficiales.

Aunque esta afirmación parezca desencaminada debido a que en la guerra civil española el bando nacional combatió contra el comunismo, es importante aclarar ciertos puntos en relación con esta perspectiva. Durante la guerra civil, la izquierda fue reducida a su componente comunista, al que 
se imputaba su carácter ateo, y por ende "antiespañol". La Iglesia aprovechó esta coyuntura histórica debido a que en ese momento de crisis total y de pugna abierta, sólo la Iglesia estaba en condiciones de ofrecer un sistema de legitimación suficiente para asentar firmemente su hegemonía ideológica. Esto fue aprovechado por el régimen franquista quien adoptó una postura en la cual desproveía a la guerra civil de todo carácter social y político para otorgarle, casi exclusivamente, significado religioso, es decir, definirla en términos de "Cruzada". Por lo tanto, la habilidad de ampararse en un patriotismo de tipo religioso aseguraba el poder personal de Franco. Cabe citar, a este propósito, a J.A. Tello quien afirma al respecto: "un régimen totalitario es aquel en que el Estado administra el poder de tal manera que la Iglesia no puede ejercer libremente sus derechos de orden divino, tales como bautismo, matrimonio, entierro, educación de la juventud y posesión de propiedades"(121). Desde el momento en que el régimen de Franco concede a la Iglesia tales derechos, no puede ser considerado totalitario, ya que no goza del poder de una forma absoluta, sino que lo comparte con la Iglesia. De igual modo, es importante subrayar cómo el carácter católico del régimen franquista fue utilizado para marcar 
la diferencia de éste respecto al nazismo alemán y el fascismo italiano.

La mitología revolucionaria cubana creó su propia modificación del ideal ascético autodefiniéndose como una revolución mesiánica con vestigios del "poder pastoral" definido por Foucault, donde se adoptaron los ideales del "misionero guevarista" de pobreza, humildad y modestia. Este "modelo franciscano" de renuncia material y principios ascéticos sirvieron de modelo generador y de ayuda al proceso revolucionario, algo verdaderamente asombroso y contradictorio en un sistema ateo. Otro componente interesante es el culto a un máximo líder, un apóstol ubicuo y omnisciente encarnado en la imagen fuerte y magnánima de la figura paternal tan común entre los dictadores.

Desde el comienzo de la Revolución Cubana, bajo el control hegemónico del Estado, las estrategias de movilización giraron en torno a una ideología revolucionaria sustentada por la mitología del "hombre nuevo" elaborada por el Che. ${ }^{8}$ Esa búsqueda del bon savage concebido por Rousseau que no conoce la codicia y que se solidarizara con los que sufren la injusticia era el aporte que Cuba intentaba brindar a la experiencia socialista universal. En el discurso oficial la formación de este tipo de individuo 
pretendía resolver genialmente la dialéctica entre lo material y lo ideológico, como también conferirle dignidad a la empresa revolucionaria. Este concepto no sólo fue entendido en el sentido literal de la interpretación del significante "hombre nuevo", sino por la autoridad única de la Revolución, con figuras paternales beatíficas y benéficas tales como Fidel Castro o el Che Guevara, que, como todos los apóstoles, proyectaban la concepción heroica de sí mismos.

Para propagar los ideales revolucionarios se consolidaron organismos que impusieron el monopolio de su propio discurso y lo identificaron arbitrariamente con la voz de la sociedad cubana. De esta manera, se establecen organizaciones tales como los Comités de Defensa de la Revolución (CDR), La Federación de Mujeres Cubanas (FMC), la Asociación de Jóvenes Comunistas (UJC), la Unión de Periodistas y Escritores de Cuba (UPEC), entre otros, para controlar y regular el acceso a los espacios de expresión. ${ }^{9}$ Ya en marzo de 1965, Ernesto Che Guevara articula esta necesidad de movilizar a las masas:

Para construir el comunismo, simultáneamente con la base material hay que hacer el hombre nuevo. De allí que sea tan importante elegir correctamente el instrumento de movilización de 
las masas. Ese instrumento debe ser de índole moral $[\ldots]$. Como ya dije, en momentos de peligro extremo es fácil potenciar los estímulos morales; para mantener su vigencia, es necesario el desarrollo de una conciencia en la que los valores adquieran categorías nuevas. La sociedad en su conjunto debe convertirse en una gigantesca escuela. (631)

Como refleja la anterior cita, el deseo del Che Guevara de convertir la sociedad en una gigantesca escuela coincide con el concepto panóptico propuesto por Foucault en relación a las prisiones y otras instituciones, en tanto que dispositivo de control y poder, y medio de vigilancia integral. El dispositivo panóptico en que se basa la sociedad cubana despliega su mirada a una amplia variedad de instituciones de secuestro donde el ser humano es focalizado como el objetivo central de control y vigilancia a través de un conjunto de mecanismos que operan en el interior de todas las redes de procedimientos de los que se sirve al poder. Por lo tanto, los organismos gubernamentales anteriormente mencionados son en realidad entidades que conforman un aparato clasificatorio para ejercer un férreo dominio sobre las instancias de representación, y, se convierten en parte de un sistema de 
censura que anula a quienes, por una razón u otra, disienten del pensamiento oficial. Para el poder hegemónico estos organismos significan la garantía de que nada se le escape, ya que sus agentes nunca serán suficientes para desarrollar esa tarea. Puesto que hay que vigilar a la población entera, es preciso que ésta se vigile a sí misma.

Visto en su conjunto, el gran aparato ideológico y represivo estatal destinado a manejar la creación de la sociedad comunista cubana responde a motivos muy similares a los del franquismo, $y$, en particular, al movimiento católico. Para percibirlo, es preciso, como ya se ha discutido anteriormente, analizar la ideología que cimentaba la actuación política de los católicos durante la dictadura en España, y, la forma en que la "cruzada moral" reflejaba y servía de soporte a su proceder político. De la misma manera que ser revolucionario es un rasgo patriótico y requisito indispensable en la Cuba castrista, durante la dictadura franquista un rasgo de la españolidad era ser católico. No se debe olvidar que en esa época al lado del crucifijo presidía el retrato de Franco y el de Primo de Rivera, y las oraciones del catecismo alternaban con el canto de "Cara al Sol". Como señala Aurora Morcillo: "Eranco, the Caudillo, became the medieval 
warrior-crusader, defender of the faith and restorer of Spanish national greatness, with his relationship to the Church as an important plank in the theatrical panoply"(28). La variedad cubana del totalitarismo exhibe una característica peculiar: ha sido conformada, más aun, debe su existencia a la personalidad sin igual de un solo individuo: Fidel Castro, quien a partir de 1959 se convirtió en figura mesiánica y emblemática del nuevo orden social cubano.

El importantísimo papel que desempeñaban la Iglesia y la fe católica en la justificación del régimen franquista daba lugar a que la censura estatal se empeñase en guardar el orden contra todo tipo de anticlericalismo e inmoralidades, y que adoptara las reglas prohibitivas del Índice. ${ }^{10}$ Para asegurar el nuevo estado católico se fundan entidades tales como la Acción Católica, la Sección Femenina, la Unión de Estudiantes Universitarios de la Falange, entre otras. ${ }^{11}$ Dichas instituciones no son, sino organismos destinados al control y a una labor de vigilancia, ya que todo aquello revestido con tintes "sociales", (asociaciones, colectivos, etcétera) permanecía subordinado al control del Caudillo. Tal como sucedió más tarde en Cuba, tanto el sistema educativo como las instituciones del estado en general fueron creados como 
agentes panópticos de adoctrinamiento para consolidar el código moral del poder, donde el sacerdote--en Cuba sería el militante revolucionario--es considerado el símbolo del más puro educador. Estas semejanzas entre la dictadura franquista y castrista se realzan aún más cuando se comparan entre sí las tácticas represivas utilizadas por ambos sistemas. En Cuba las grandes festividades revolucionarias se asemejan a los actos patrióticos de afirmación falangista: el despliegue de banderas, la estridencia de las consignas, la invocación a los mártires de la patria, las canciones y lemas patrioteros, la integridad de la nación y la supremacía del caudillodictador para acallar sin contemplaciones la menor veleidad de protesta de los intelectuales y escritores. Esta situación engendró la paranoia de aquellos de los que se sospechara de traición al nuevo estado.

Dentro de las sociedades autoritarias, cualquiera que sea su ideología o religión, la expresión literaria es una de las manifestaciones que siempre sufre más represión. Es comprensible que las instancias del poder desconfien de las ficciones y las sometan a fuertes censuras ya que "salir de sí mismo, ser otro, aunque sea ilusoriamente, es una manera de ser menos esclavo y de experimentar los riesgos de la libertad" (Vargas Llosa 13). El miedo a la nocividad de 
la literatura y a los que la crean es casi obsesivo en los regímenes que aspiran al control total porque como decía el escritor ruso Soljenitsin, "un gobierno no quiere escritores, sólo quiere amanuenses". Esto se evidencia en España en el intervalo de 1936 a 1939. Durante el cruento acaecer de la guerra civil pocas obras literarias se dan a conocer en el país. A partir de 1939 se impone el silencio tras la dispersión de gran número de escritores lanzados al exilio por temor a las represalias impuestas dentro del país, quedando el panorama literario de aquel momento paralizado. Como resultado, los escritores españoles se vieron obligados a someter sus obras a una censura previa que aún en 1960 la Real Academia Española denunciaba (Guillermo 11).

Una situación similar ocurrió en Cuba desde los primeros años de la Revolución, donde la censura literaria ha sido aguda desde el comienzo del régimen cubano. Es preciso señalar que ya en 1964 y 1965 en Cuba había campos de trabajo forzado, que se llamaban la UMAP, donde llevaban a intelectuales disidentes (Arenas 252). El famoso discurso de Fidel Castro a los intelectuales donde proclamaba las proféticas palabras "con la Revolución todo, sin la Revolución nada", dan fe de la obligatoriedad del 
escritor de estar conectado intrínsicamente a la voluntad revolucionaria y de promover los ideales de ésta:

$Y$ es correcto que un escritor y artista que no sienta verdaderamente como revolucionario se plantee ese problema; es decir, que un escritor $y$ artista honesto, que sea capaz de comprender toda la razón de ser y la justicia de la Revolución sin incorporarse a ella se plantee este problema. Porque el revolucionario pone algo por encima de todas las demás cuestiones; el revolucionario pone algo por encima aún de su propio espíritu creador: pone la Revolución por encima de todo lo demás y el artista más revolucionario sería aquel que estuviera dispuesto a sacrificar hasta su propia vocación artística por la Revolución. (Castro, Palabras a los intelectuales 5)

Como se puede apreciar en la anterior cita, cualquier intento literario que se desvíe de los presupuestos estéticos e ideológicos revolucionarios es anatema en la isla caribeña. Las editoriales en Cuba son editoriales estatales, no existe ninguna opción de publicar en otras, las únicas existentes son la Casa de las Américas y la Unión de Escritores y Artistas de Cuba, la UNEAC. Esta realidad se ha evidenciado en la trayectoria de todas esas 
voces disidentes de escritores y periodistas que no han tenido otra opción que permanecer junto a la fragua de la servidumbre y hacer una literatura de sumisión al régimen, o impugnar la tiranía desde el extranjero. Como afirmó Reinaldo Arenas:

Yo, entonces, viendo que tenía la opción de hacer una literatura de cantos optimistas a aquel sistema que de hecho era una dictadura más cruel que la que yo había padecido anteriormente, que era la de Batista, opté por una actitud de libertad. Opté por escribir sin censura, aunque sabía que esa obra no se iba a publicar en Cuba, pero mi necesidad de escribir era más poderosa que la vanidad de publicar. (252)

Es indudable que la importancia emblemática de "paraíso prometido" y encarnación de la liberación que la Revolución cubana tuvo para los países oprimidos es hoy sólo un mito; la utopía castrista ha decepcionado hasta a los más notorios incondicionales de la mitología revolucionaria. ${ }^{12}$ A pesar de que escritores como Alejo Carpentier solían decir que los malos escritores eran los que se peleaban con la izquierda, y que poca gente estaba dispuesta a arriesgar su imagen de denuncia contra Cuba, lo cierto es que la revolución ha perdido hoy en día gran 
parte de su poder de seducción. La gran mayoría de los intelectuales y la izquierda--con la excepción de una minoría--que han apoyado y elogiado al "primer-territoriolibre-de-América" por casi medio siglo, y que tanto han pontificado a su máximo líder, hoy repudian y condenan el totalitarismo castrista debido a que los postulados de dicho régimen son tan contrarios a la libertad intelectual, que sólo mediante la coacción pueden ser impuestos en la sociedad.

En el régimen castrista el acceso a la información está firmemente controlado y regulado por los principales organismos del país. Una larga lista de libros y autores están proscritos y vedados en las librerías, bibliotecas, escuelas y universidades cubanas por ser considerados "nocivos" y atentar contra la ideología de la conciencia revolucionaria. El acceso a estos textos puede tener graves consecuencias para aquéllos que infringen esos decretos. Como ha ocurrido en la última oleada represiva de ejecuciones y encarcelamientos en Cuba en marzo de 2003, a diferencia del resto del mundo occidental, se va a la cárcel por escribir o leer un periódico. Los excesos con que el régimen castrista sacude las conciencias de los que se atreven a increpar y pensar diferente se evidencia en la 
aplicación de la "ley de peligrosidad", digna del Santo oficio. ${ }^{13}$

Esta situación evoca lo que acaeció en España a comienzos de los años cuarenta, cuando la Iglesia católica, que ya se preocupaba desde la Inquisición por la moralidad de los libros, muestra en estos años una particular inquietud. De esta época de "confusionismo doctrinal y de convencionalismo moral" data, por ejemplo, una circular de la Sagrada Congregación del Santo Oficio que pone de relieve "la necesidad de prevenir a las juventudes de las lecturas de libros perniciosos para la fe y las buenas costumbres". ${ }^{14}$ No solamente son prohibidos muchos de los escritores nacionales tales como Unamuno, Pío Baroja, Galdós, Clarín por razones más o menos obvias, sino también una segunda categoría de publicaciones sobre cuestiones políticas e históricas, la cual incluye, por ejemplo, obras de Maurras, de Croce, Gentile, Jovellanos, Montesquieu, Rousseau y Voltaire; por último, la prohibición de obras literarias, como las de Balzac, Dumas, Stendhal, Zola y D'Annunzio. De igual forma, los modelos de la novelística inglesa, norteamericana y francesa que estaban marcando pautas en el ambiente literario de la época quedaron prácticamente reducidos a cero. Respecto a esta educación 
restrictiva del franquismo Goytisolo subraya en Cogitus interruptus:

Los profesores--jesuitas, hermanos o seglares-no me enseñaron cosa de utilidad perdurable: sólo una acumulación engorrosa de datos y hechos rápidamente olvidados después de los exámenes en virtud de una saludable selectividad natural del cerebro. Preceptos religiosos, silogismos escolásticos, operaciones matemáticas cordialmente odiadas por mí, se disolvieron en la nada como los artículos del Código Civil que me vi obligado a memorizar 10 años más tarde. Con excepción de las nociones elementales de gramática castellana, nada de cuanto me expusieron en el campo de las letras contribuyó a mi formación futura. Las lecciones escasas de latín y griego, la deficiente instrucción en francés e inglés no me permitieron penetrar en el ámbito de esas lenguas. (9-10)

Sin embargo, a pesar de que los regímenes totalitarios tienden a condenar a los intelectuales al anatema inquisitorial, no es menos cierto que cada vez que circunstancias importantes han alterado radicalmente el curso de la historia, los artistas han sabido, mejor que 
los sociólogos, percibir la importancia de los cambios y verter en sus obras la intensidad de las inquietudes y angustias de su generación para escribir la verdad de la historia. Como asevera Vargas Llosa: "La literatura cuenta la historia que la historia que escriben los historiadores no sabe ni puede contar" (14). De ahí que en donde exista la falta de libertades políticas elementales--como ha sido el caso de España y el de la isla de Cuba bajo el régimen castrista--el intelectual auténtico rehúsa someterse al poder y lucha por el derecho de pensar por sí mismo aunque se vea condenado al silencio o al ostracismo moral. Si no se rebela está condenado a morir en vida, a convertirse en un robot sin posibilidades de innovación y creación. Estas reflexiones nos hacen plantearnos la pregunta ¿qué es un intelectual entonces? Para contestarla, podríamos evocar las sugestivas reflexiones del crítico búlgaro Tzvetan Todorov, formuladas en su libro El hombre desplazado (1996). El autor, como buen sociólogo, se muestra particularmente atento a las implicaciones políticas en la creación, y, como ya hemos mencionado al principio de este capítulo, al contexto socio-histórico al que pertenecen los creadores. Todorov define al intelectual de esta manera: 
¿Qué es un intelectual? Por lo que a mí respecta, limito el uso de este término de la siguiente manera: es un estudioso o un artista (categoría que incluye a los escritores) que no se contenta con realizar trabajos científicos o con la creación de una obra de arte, que no se contenta, por lo tanto, con la mera búsqueda de lo verdadero y con un mero desarrollo de lo bello, sino que se siente asimismo comprometido con la noción del bienestar público, con los valores de la sociedad en la que vive, es alguien que participa en el debate sobre esos mismos valores. El intelectual así entendido se halla muy lejos del artista o del estudioso a quienes no preocupan en absoluto las dimensiones políticas o éticas de sus obras; muy lejos, también, del predicador o del político profesional, que no crean obra alguna. (163)

Juan Goytisolo y Zoé Valdés se acercan a la figura del intelectual propuesta por Todorov al asumir un discurso político y de compromiso social que lucha por romper las ataduras de sumisión con regímenes dictatoriales que limitan a sus ciudadanos a participar en la elección de cosas tan elementales como son leer un libro, un periódico 
con diferentes opiniones a las del gobierno, escoger una película no censurada, o escuchar una canción. En ambos escritores, aunque parezcan disímiles, se detecta una afinidad y un paralelismo temático convergentes que explicaremos más adelante.

En este capítulo nos centramos en el tema de la represión como elemento catalizador y determinante en la narrativa de estos autores, pero, sobre todo, en la forma en que las estructuras autocráticas configuran la misma. Como tantos estudiosos de la obra de Goytisolo han observado, el autor español vierte en su escritura un discurso acérrimo y obsesivo contra Franco y su dictadura, clamando en sus novelas y ensayos por la destrucción del tirano y su régimen para exorcizar así su sed de venganza y sus reivindicaciones personales. Sus vivencias han sido tan alienantes, que en sus ensayos y artículos recogidos en Libertad, Libertad, el escritor afirma:

Algún día la psiquiatría española deberá analizar seriamente los resultados de esta tutela maligna sobre una masa de adultos constreñidos a soportar una imagen degradada de sí mismos y asumir ante los demás una conducta inválida, infantil o culpable. Las represiones y tabúes, los hábitos mentales de sumisión al poder, de aceptación 
acrítica de los valores oficiales que hoy nos condicionan no se desarraigarán en un día. Enseñar a cada español a pensar y actuar por su cuenta será una labor difícil, independientemente de las vicisitudes políticas del momento. (17) Como se puede observar, Goytisolo intenta psicoanalizar a la sociedad española y a sí mismo, empresa a la que ha dedicado toda su vida. Las obras que analizaremos en los capítulos a continuación--la trilogía compuesta por Señas de Identidad, Juan sin tierra $y$ Reivindicación del conde don Julián--están basadas parcialmente en material autobiográfico. Son novelas exageradamente autorreflexivas y críticas de los más arraigados mitos españoles de identidad nacional. En las mismas subyace el deseo de racionalizar los efectos psicológicos sufridos por una traumatizante represión, la cual, el mismo autor admite, es un elemento que abona el terreno para la neurosis, la agresividad y los pequeños infiernos privados. De hecho, como ha afirmado en sus ensayos y entrevistas, frente a la presión del poder, el individuo, y sobre todo el escritor, adopta una estrategia de desdoblamiento esquizofrénico que lo condena "al arte sinuoso de escribir y leer entre líneas, a tener siempre presente la existencia de un censor investido de la 
monstruosa facultad de mutilarlos" (Pájaro 24). Por lo tanto, la conciencia individual se vuelve en esas condiciones hipócrita, cínica, egoísta, ya que salir a flote parece ser la única vía alternativa en esos casos. Por su parte, Zoé Valdés es producto de una realidad sociopolítica tan hiperbólica como su propia escritura. Su obra, al igual que la de Goytisolo, es autorreferencial, contestataria y desmitificadora. Como puntualiza Madeline Cámara, Zoé ha llevado a su máxima tensión el discurso femenino en las condiciones históricas y dentro del canon literario al que pertenece (21). Nunca antes en la literatura cubana mujer alguna se ha atrevido a tal violencia discursiva donde se entremezclan lo erótico y escatológico con lo político. El realismo de su discurso es portador de la voz contestataria del pueblo, y al mismo tiempo, doblemente disidente por ser antirrevolucionario y feminista. Los estragos de sus vivencias dentro de una revolución orientada hacia el hombre, sirven de marco referencial a una novelística que arremete contra el sistema castrista combinando desacralización y choteo; desmitificando el discurso oficial que declara que existe igualdad a todo nivel.

La más prolífica escritora cubana es un fenómeno posmoderno donde se perciben reflexiones críticas que están 
impregnadas, tanto de unos códigos políticos, como de la demanda editorial que ha explotado y aprovechado la coyuntura socio-histórica cubana. La carencia de trabajos críticos sobre la obra novelística de la escritora cubana, ha suscitado opiniones divergentes sobre el valor literario de su obra. Valdés asegura que incluso las aparentes oraciones agramaticales y las deficiencias estilísticas son intencionales; se propone transgredir y exponer irónicamente los valores de la Cuba que le tocó vivir. Pero sea cual fuere la opinión al respecto, habrá que convenir en que pocos autores cubanos, y mucho menos mujeres, han logrado tener tal éxito editorial y una resonancia tan internacional.

Uno de los aspectos particularmente interesantes en la novelística de Valdés es su alejamiento temático respecto a sus coetáneas residentes en la isla. Aun cuando esas escritoras de finales de los ochenta y principios de los noventa, denominadas "novísimas", abordan temas más individuales, y se alejan de los conflictos colectivos tan evidentes en la generación que escribía durante el auge de la revolución, la nueva literatura cubana escrita por mujeres carece de una crítica explícita a la situación socio-política debido a que todavía se produce bajo una censura. ${ }^{15}$ Aunque Madeline Cámara considera que la 
literatura feminista contemporánea cubana trata de dar agencia a voces no hegemónicas, esta afirmación no parece ser, sin embargo, exacta. Aun en su mejor exponente, Ena Lucía Portela (La Habana, 1968), no se da la denuncia política tan evidente que encontramos en Valdés. ${ }^{16}$ Lo novedoso en los textos de la escritora cubana no es sólo la identificación nación y sujeto, sino el frontal ataque a lo que la escritora considera la gran impostura masculina representada por un régimen totalitario masculino por decreto, y descrita con gran precisión por Ruth Behar: Fidel became inseparable from the revolution and from the nation--the nation gendered as male, or la patria, the fatherland. To dissent from the revolution was to dissent from Fidel. To dissent from Fidel, in turn, was to be apatria, nationless, un-Cuban, fatherless. This dynamic of "Fidel-patria-revolution" was rooted in a form of authoritarian state power whose sexual politics privileged the male charismatic revolutionary. Only the heterosexual male revolutionary could confront the emasculating power of U.S. imperialism. The revolution called for an ultravirile sense of national identity. (138) 
Como se puede observar, la revolución cubana tiene un enfoque machista, es la obra de super hombres heroicos, con una dirigencia política, como han señalado varios críticos, pletórica de testosterona. En ese proceso tan marcadamente varonil la mujer está subordinada, no tiene ningún poder, queda relegada, como es de suponer, a un segundo plano. Como Valdés misma ha afirmado:

No ha habido hasta hoy humillación más perversa por el nivel de sutileza en la tortura que la que ha infligido la dictadura castrista a la mujer cubana. Mientras la aplasta dice que le está dando derechos. ¡Es increíble! Soy mujer y aunque no me diera cuenta, todo esto me revuelve, sacude y repulsa, lo viví, lo sufrí. Y siempre he creído en la libertad, aún cuando ni siquiera soñaba con poder conquistarla. (Entrevista personal)

Es por eso, que para combatir esta realidad, Valdés intenta una escritura nueva y transgresora que le permita llevar a cabo las rupturas y transformaciones necesarias a dos niveles inseparables: el personal (mujer-ciudadana) y el colectivo (representado por el pueblo cubano) para poder recuperar así la libertad confiscada por el poder falocrático. Su novelística es una inversión del orden 
patriarcal al apropiarse de un lenguaje erótico y unos mecanismos generalmente utilizados por los hombres para denunciar con vehemencia lo que acontece en su país. Juan Goytisolo y Zoé Valdés, cada uno dentro de un estilo escriturario propio, dan fe de la atrofia espiritual propia de aquéllos que han sufrido sistemas opresores. Ambos fabrican un mundo autárquico donde la escritura tiene no sólo un valor testimonial, sino un poder catártico. La expresión artística de sus propias visiones infernales se convierte en una tentativa de liberación para expresar las ansiedades propias, y de todos aquellos que siguen, como hipnotizados, sin rebelarse, obedeciendo las órdenes impuestas. La labor del escritor en general, y específicamente la labor de los escritores en cuestión, se percibe bajo este enfoque como una tarea deconstructora y recodificadora de los sistemas políticos que asfixian al individuo e invalidan su discurso. Esto es posible y se da con más agudeza en el artista por ser, por lo general, un individuo disconforme, anárquico, contradictorio e inadaptado, y porque en buena medida es precisamente su desafecto a la realidad que le ha tocado vivir lo que lo lleva a crear otra realidad en su arte.

En el caso de Goytisolo, varios críticos se han cuestionado: ¿quién es Juan Goytisolo? El escritor es una 
especie de enigma difícil de descifrar y definir para muchos. La complejidad de sus textos donde se muestra a veces paródico, violento y caricaturesco, y en otras instancias contemplativo y poético, ha contribuido a que los estudiosos de su obra se sientan a la vez atraídos y vacilantes hacia su creación literaria. De igual forma, sus criterios políticos mezclan ideas izquierdistas y derechistas al descubrir, después de su exilio en París, que los regímenes comunistas, como es el caso de Cuba, se sirven de los mismos mecanismos represores que el régimen franquista. En lo político, protesta contra Franco, pero también contra Fidel Castro, tan dictador como aquél desde su punto de vista. De ahí que el franquismo no sea el único objeto de las invectivas del escritor español, sino que, por el contrario, éstas se dirigen hacia toda ideología dogmática que "como todas las sectas religiosas poseedoras de la verdad, imprime una suerte de carácter sacramental a sus miembros y transforma a momentos el rostro de éstos en una insondable máscara" (Reinos de Taifa 69). Su compleja y contradictoria personalidad parece ilustrar la secuela de haber vivido en una asfixiante estructura represiva. Esto no sólo se evidencia en su obra, sino también en su propia vida. Al ser cuestionado sobre esa reputación de fronterizo, de iconoclasta, de haberse ganado a pulso el 
ser un ejemplar de "pájaro que ensucia su propio nido", responde:

Pues el pájaro que ensucia su propio nido no se recata y enmugrece también algunos ajenos. Soy así un pájaro aguafiestas en todas las acepciones del término; ajeno a grupos de intereses, estamentos y bandas, preocupado tan sólo por afinar el canto. Pero, cuanto más clara es una voz, más, disonante suena. No hay coro a quien le guste y su aislamiento estético adquiere dimensiones físicas. (Pájaro 405)

Estas revelaciones muestran, paradójicamente, cómo el controvertido escritor está destinado a ser un "cantor solitario", un apátrida que no encaja en corriente alguna, ni abandona la estela perfilada en La Reivindicación del conde don Julián. Es importante señalar que en obras postfranquistas recientes se manifiesta reiteradamente la misma preocupación y marcado interés del escritor por la sociedad española y el talante de los españoles. En Pájaro que ensucia su propio nido, su pasión crítica por España continúa. Según él, esta nueva España, que después que cesó de ser un país desdichado y pobre, es habitada ahora por esos "nuevos ricos, nuevos libres y nuevos europeos, que aborrecen al moro y desprecian al 'sudaca'"(404). Como 
se puede observar, Goytisolo es un autor marcado por un ostracismo autoimpuesto y demoledor. Está poseído, como afirmaría Kristeva, por la abyección en una catarsis indefinida ya que "Il y a, dans l'abjection, une de ces violentes et obscures révoltes de l'être contre ce qui le menace et qui lui paraît venir d'un dehors ou d'un dedans exorbitant, jeté à côté du possible, du tolérable, du pensable" (Kristeva 9). Esta relación de Goytisolo con su cultura es una complicada historia de amor y odio donde el autor se autodefine como "hereje", "muladí", "renegado", entre otros epítetos. Esto explica porqué su producción narrativa y ensayística posterior a la dictadura franquista continúa siendo tan disidente y contestataria como al principio de su carrera literaria; sus discursos estéticos e ideológicos siguen mezclándose en su escritura con la misma introspección y contradicción personal y social de siempre.

La crítica literaria de índole psicoanalista, sobre todo la feminista, cuenta con varios ejemplos de lectura crítica basada en las teorías de Sigmund Freud, Jacques Lacan y Kristeva, entre muchos otros. Sin embargo, la crítica no ha establecido las bases que ponen en evidencia la necesidad de una aproximación psicológica que explore los efectos de la represión y la censura en estos 
escritores para luego ubicarlos y correlacionarlos con los textos de los mismos. No es nuestra intención hacer un análisis minucioso del perfil psicológico de los autores en cuestión--perfilar el retrato psicológico y moral del escritor, fue objeto prioritario de programas ligados a teorías románticas--pero sí estudiar las consecuencias de la imposición de una especie de camisa de fuerza para constringir toda expresión artística. A través de nuestro criterio sobre esa realidad represiva hemos establecido las bases valorativas que corresponden a las metas de este capítulo, ya que pensamos que es un componente importante para comprender, no sólo la violencia discursiva de los escritores analizados en esta tesis, sino también ciertas realidades existentes en el ámbito de la psicología individual y colectiva.

El artista es, en general, un ser disconforme y antagónico. Según los presupuesto del concepto "inconsciente político" de Jameson, es también por naturaleza un ser dialéctico, político y social. El texto literario, directa o indirectamente, tácita o explícitamente, no se encuentra desarticulado jamás de las condiciones de la existencia concreta de su tiempo y lugar porque la tarea del escritor, consciente o inconscientemente, es la de entrever los valores eternos 
que están implicados en el drama social y político de su entorno. La relación íntima entre el artista y su circunstancia es indudable; por eso, durante la época en que escribía Madame Bovary, Flaubert escribe en su Correspondencia: "mes personnages imaginaires m'affecten, me poursuivent, ou plutôt, c'est moi qui suis en eux". De igual modo, Proust no pudo haberse formado en una tribu africana o esquimal. Su obra refleja los selectos y exquisitos salones parisinos que tan asiduamente frecuentó, donde se fraguaban devastadores idilios amorosos. Es por eso que después de Marcel Proust la palabra "amor" ya no significa lo mismo.

Asimismo, si Goytisolo ataca a los mitos más arraigados de la sociedad española, y Zoé Valdés desestabiliza los centros del poder falocentrista con la insolencia de las peores y malsonantes palabras del léxico castellano y el argot cubano; si ambos arremeten contra las estructuras del poder con un discurso donde lo erótico cumple una función transgresora, es por ser una realidad condicionante en la psiquis de ambos escritores. Goytisolo ofrece el testimonio de un homosexual en una sociedad inquisitorial machista dominada por los preceptos de una religión que confiere a lo sexual un carácter represor, un enigma inquietante, secreto y misterioso. De igual modo, Valdés nos ofrece la 
perspectiva de una mujer subyugada doblemente por un sistema represivo y machista, condenada junto con su pueblo a la consigna letal de "patria o muerte". Son escritores que sienten la necesidad oscura pero obsesiva de testimoniar su drama, su desdicha, su soledad. Escriben con desgarro, con una violencia acérrima porque inevitablemente están ofreciendo el testimonio de ellos, del mundo en que viven y de la condición humana de su tiempo y circunstancia.

Sobre lo ya dicho, es necesario analizar ciertos aspectos de la represión sexual y su manifestación en lo corporal debido a que es un componente importante en los sistemas totalitarios. Es evidente que a lo largo de la historia de las civilizaciones, el cuerpo ha sido el eje en torno al cual giran las concepciones religiosas y sociales. Como examina Goytisolo en Disidencias, la actitud tradicional de la cultura española con respecto al ocultamiento del cuerpo desde los Reyes Católicos tiene su origen en la destrucción de lo árabe durante la Reconquista, ya que la visión del erotismo islámico difiere de la del cristianismo, y por extensión, de la del catolicismo (118). El tema nos remite de nuevo a Foucault, quien afirma que el aceptar el sexo en su realidad es tan ajeno al hilo de una historia ya milenaria como es hostil a los mecanismos intrínsicos del poder, 
debido a que a partir de la edad clásica la represión ha sido el modo fundamental de relación entre poder, saber y sexualidad.

Como es sabido, en La Volonté de Savoir (1976)

Foucault presentaba el bosquejo metodológico de una serie de seis volúmenes consagrados a la historia de la sexualidad titulado Histoire de la sexualité donde el teórico francés deseaba efectuar un estudio genealógico que mostrara los cauces inesperados por los que se había constituido históricamente, la experiencia de la sexualidad. El tema es tan intrigante para él mismo, que lo insta a interrogarse: "¿Por qué, pues, el sexo es tan secreto? ¿qué fuerza es esa que tanto tiempo lo redujo al silencio y que apenas acaba de aflojarse, permitiéndonos quizá interrogarlo, pero siempre a partir y a través de su represión?" (La voluntad 97). La sexualidad, de acuerdo al teórico francés, se definió "por naturaleza" como un campo de significaciones que descifrar; una palabra oscura que hay que desemboscar, y, a la vez, escuchar; es según él, la "economía" de los discursos.

Es evidente que en la novelística de Goytisolo y Valdés el referente erótico es un arma hábilmente utilizada por estos escritores para impugnar y desmitificar la dominación hegemónica. Ambos fustigan el orden, denuncian 
las hipocresías, hacen énfasis en un discurso destinado a decir la verdad sobre el sexo, a modificar su economía en lo real, a subvertir la ley que lo rige. Como afirma Foucault en La voluntad de saber:

Si el sexo está reprimido, es decir, destinado a la prohibición, a la inexistencia y al mutismo, el solo hecho de hablar de él, y de hablar de su represión, posee como un aire de trasgresión deliberada. Quien usa ese lenguaje hasta cierto punto se coloca fuera del poder; hace tambalearse la ley; anticipa, aunque sea poco, la libertad futura. (13)

El enfrentamiento con el poder constituye la fascinación y hasta la obsesión de Goytisolo y Zoé Valdés; parece ser el sueño dorado y la pesadilla de ambos. La sexualidad, como se ha apuntado anteriormente, es la forma prioritaria para ellos de mostrar su individualidad, de obtener un espacio propio; por eso lo corporal ocupa un lugar tan importante en sus obras. Valdés explica que "in Cuba, the sexual act, the moment of orgasm, is the only time that one is truly free" (Rohter E2). En otra entrevista expone su opinión sobre el significado político de la prostitución: 
A los cubanos lo único que les queda es la tocadera, el sexo. Y esto se ha convertido en una forma de resolver la vida. Cuba es el burdel de todo el mundo gracias al estímulo de la prohibición. Ser puta en Cuba cobra una dimensión política enorme, es una reacción contra el Gobierno, con lo cual no sientes que estás haciendo algo deshonesto, sientes que estás siendo contestataria con tu cuerpo: una realidad pornográfica. (La Revista S/N)

Estos escritores están conscientes de que el poder no se contenta con funcionar como un superego freudiano, no se limita a reprimir, a acotar el acceso a la realidad, a impedir la formulación de un discurso: el poder se dirige al cuerpo. La represión sexual sirve para convertir el cuerpo humano en fuerza de trabajo, para mantener así más fácilmente a los seres humanos en un estado de sometimiento, al igual que la castración de ciertos animales sirve para asegurarse bestias de carga. De ahí que el poder político a través de ciertos mecanismos trate de incardinarse en el cuerpo y la sexualidad, y de su obstaculización, prohibición o invalidación.

Sin embargo, si algún mérito hay que reconocer a la censura es el de haber estimulado en el escritor la 
búsqueda de las técnicas necesarias para burlarla e introducir en su obra la ideología o temática "prohibidas". La existencia de la censura, la prensa controlada y dirigida, la rigidez e inflexibilidad de la sociedad son factores estimulantes para un espíritu libre y audaz. Son elementos provechosos y útiles para el desenvolvimiento de la creación artística y para romper los obstáculos que limitan y frustran a los creadores. Enfrentada a las barreras alzadas por el conservadurismo y la intolerancia, la vocación artística arremete contra dichas estructuras de acuerdo al grado de represión, y de ello dan fe las obras de Juan Goytisolo y Zoé Valdés. Sus textos, fronterizos y controvertidos, testimonian las ignominias del universo franquista y el "paraíso socialista"; ilustran una forma de abyección que desmitifica los centros religiosos, políticos, morales, y verbales del poder "car l'abjectîn est en somme l'autre côté des codes religieux, moraux, idéologiques, sur lesquels reposent le sommeil des individus et les accalmies des sociétés"(Kristeva, 246). Es ése el gran horizonte de recepción desde el cual se debe leer la subversión de las obras de Juan Goytisolo y Zoé Valdés, y, desde el cual se analizará, en los próximos capítulos, la forma en que los planteamientos aquí expuestos repercute sobre la narración de ambos. 
Notas

1 La problemática de la función estética de la narrativa y su relación con las condiciones socio-políticas ha sido tema de mucho debate entre los estructuralistas. En su estudio Roman Jakobson arguye que el arte es parte integral de la estructura social, un componente que se interrelaciona con los demás y es mutable entre sí debido a que los dominios del arte y su relación con los otros constituyentes de la estructura social se encuentran en constante flujo dialéctico.

2 Tomamos prestado el término utilizado por Kristeva en "Un nuevo tipo de intelectual: el disidente".

3 El "Período Especial" fue la denominación usada por el gobierno para definir la grave crisis en la economía cubana a raíz de la caída del muro de Berlín, lo que significó la desintegración del bloque comunista y, por extensión, el apoyo que recibía la isla de la Unión Soviética.

4 En El furgón de cola, Goytisolo escribe cómo el gran Larra, al analizar las letras españolas del Siglo de oro, había observado con gran agudeza cómo: "Géneros enteros de la literatura han debido a la tiranía y a la dificultad de expresar los escritores sus pensamientos francamente una importancia que sin eso rara vez hubieran conseguido [...] La lucha que se establece entre el poder opresor y el oprimido ofrece a éste ocasiones sin fin de rehuir la ley $y$, de eludirla ingeniosamente"(56).

5 Fernando Aínsa argumenta cómo en el encuentro del "yo" en relación con "el otro"ocurre una "alteridad". Por lo tanto, el objeto de toda conquista y colonización es erradicar las diferencias del otro y nada mejor para ello que convertirlo a la propia creencia.

6 Las observaciones de Américo Castro se recogen en Cartas de Américo Castro a Juan Goytisolo.

7 Goytisolo recoge y elabora en sus escritos posteriores la equiparación establecida por Américo Castro en el epistolario entre los dogmas y procedimientos implantados por los regímenes marxistas y los de la Iglesia, parodiando así la dictadura cubana y otros estados 
comunistas, como se ve, por ejemplo, en el capítulo quinto de Juan sin tierra (1975). La oportunidad de explorar libremente los postulados marxistas habrá de tener influencia decisiva en la elaboración de su credo personal.

8 Curiosamente, en la misma línea de construir un nuevo ser humano que abrace incondicionalmente la ideología impuesta por el orden establecido, durante los albores de la Guerra Civil española, en un discurso de ofrenda a Santiago pronunciado en 1937, el Cardenal Gomá diría en tono profético: "la guerra [...] viene a ser una especie de purificación colectiva de la que va a salir el español nuevo, a semejanza del hombre nuevo del evangelio". (473)

9 Es importante para nuestro estudio, señalar la importancia de La Federación de Mujeres Cubana. La FMC es y se define como una institución creada para la mujer con el objetivo de servir desinteresadamente a la revolución. "La revolucionaria" acepta servir a la Revolución según los derechos que le hayan otorgado para usarlos tal y como se los define la hegemonía a la cual se los debe. Según los discursos de los congresos de la FMC, la compañera --término adoptado durante la revolución--se dedica a "la labor abnegada y consciente en la edificación de la sociedad socialista"(Espín 47). Es interesante subrayar que de igual manera que en la España franquista las funciones culturales y sociales de la Sección Femenina fueron cruciales para el adoctrinamiento femenino, la Federación de Mujeres Cubana realizaría la misma función usando el discurso de abnegación y sacrificio dentro de la conceptualización del sujeto femenino basada en una construcción género-sexual tradicional.

10 Aunque la penetración clerical en el aparato censor no llegó a formalizarse hasta febrero de 1947 según una circular del Cardenal primado del 28 de febrero de 1947, publicada en Ecclesia 297 (1947).

11 La fundación en 1941 de la revista Ecclesia, órgano oficial de la Acción Católica, organización que por su parte--por medio de su Junta Nacional--dependía de la Conferencia Episcopal, es un hecho ilustrativo de las nuevas oportunidades ante las cuales la Iglesia, gracias a las circunstancias políticas creadas por el nuevo régimen, se vio puesta. La ofensiva que emprendió a fin de catequizar a la sociedad, tenía como consecuencia peculiar 
la aparición de una censura literaria que había de complementar la censura estatal, aunque ésta ciertamente no descuidaba las exigencias del sector católico del régimen en este terreno. Se trataba de críticas, consejos y avisos que aparecían semanalmente, y que se referían a toda clase de libros, señalando su mayor o menor grado de rectitud moral.

12 Goytisolo fue uno de los primeros intelectuales que cambió su actitud hacia Cuba. Gould Levine cita la carta --que obtiene de los archivos de Goytisolo en Boston University--enviada por un grupo de intelectuales a Castro en protesta del encarcelamiento de Heberto Padilla. Esta carta, escrita por Goytisolo y Cortázar, contiene la siguiente condena del régimen castrista, según el texto citado en The New York Times (22 mayo, 1971).

We hold that it is our duty to inform you of our shame and anger. The deplorable text of the confession signed by Heberto Padilla can only have been obtained by means that amount to the negation of revolutionary legality and justice ... [It is] with the same vehemence that from the very first day was ours in defending the Cuban Revolution, which seemed to us exemplary in its respect for the human being and its struggle for liberation, that we exhort you to spare Cuba dogmatic obscurantism, cultural xenophobia and the repressive system imposed by stalinism on the social countries and of which events similar to those now occurring in Cuba were flagrant manifestations... We would want the Cuban Revolution to return to what made us consider it as a model in the realm of socialism. (Gould Levine 262)

13 La ley de peligrosidad artículo 72 del Código Penal dice: "se considera estado peligroso la especial proclividad en que se halla una persona para cometer delitos, demostrada por la conducta que observa en contradicción manifiesta con las normas de la moral socialista."

14 Para más información al respecto, consultar el artículo "¿Qué libros y autores puedo leer?", por el viceconsiliario, Benito Fuentes Isla, y el director, 
Francisco Cervera, del Secretariado de orientación Bibliográfica, 1 de enero de 1944; en Ecclesia 1S (1944): 14-15.

15 El término "novísimos" fue acuñado por Salvador Redonet en su libro Los últimos serán los primeros. Nara Araújo en "Lo cubano and the Literatura of the Novísimas" define el término de la siguiente manera: "Novisimas' is the name given to a group of writers born in Cuba in the $1960 \mathrm{~s}$ and 70s, who in the 1980s changed the models of women's writing on the island"(223).

16 La obra de Ena Lucía Portela permanece casi inédita, a pesar que muchos de sus cuentos han aparecido en antologías y revistas. Según Madeline Cámara sostiene en La letra rebelde, Portela aborda asuntos hasta hace poco ausentes en la literatura cubana, tales como la situación de los jóvenes marginados que socialmente se agrupan en torno al "heavy-rock", experimentan con drogas, y siguen ciertas manifestaciones extravagantes de la moda(90). 
CAPITULO II

IA CONSTRUCCIÓN Y DECONSTRUCCIÓN DISCURSIVA

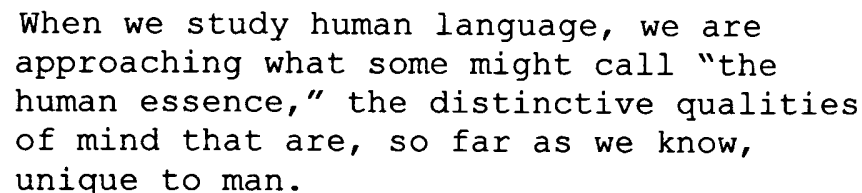

unique to man.

Noam Chomsky

...El lenguaje dice siempre algo más que su inaccesible sentido literal, que se pierde ya en cuanto se inicia la emisión textual.

\section{Umberto Eco}

El lenguaje es uno de los problemas más controvertidos del pensamiento filosófico. Ninguna otra episteme ha sido sometida a tan profundo revisionismo. Somos, como ha expuesto Lacan, antes que nada un ser de lenguaje. ${ }^{1}$ El lenguaje es el componente que vertebra nuestra existencia, es donde nos reconocemos y existimos humanamente porque sin una manera de designar al ser, no habría lenguaje; pero sin lenguaje, no habría el verbo "ser", que sólo es una parte de aquél. ${ }^{2}$

Ante estas reflexiones nos preguntamos entonces: ¿qué es el lenguaje? Para esta interrogante hay varias y encontradas respuestas de filósofos y lingüistas por igual que han formulado sus propias teorías sobre el tema. Entre ellos, se encuentran Mijail Bajtín, Julia Kristeva, Michael Foucault, Roland Barthes y Jacques Derrida.

Desde las perspectivas de estos teóricos, sus tesis sobre el lenguaje, y sus modelos de análisis, pretendemos 
hacer un más amplio recorrido a través de la obra literaria de Juan Goytisolo y Zoé Valdés. Al intentar analizar el discurso desmitificador de los autores en cuestión, es esencial tener en cuenta esa frontera donde se sostiene hoy en día la batalla teórica para una nueva definición del papel de la interpretación. Aunque muchas de estas teorías son iluminadoras, ninguna es plenamente satisfactoria, porque siempre cabe descubrir casos dudosos, rebeldes o fronterizos. La teorización de la interpretación de Saussure,--signo, significante y significado--es una especie de laberinto donde en ausencia de patrones, esquemas, modelos, sistemas e hilos conductores supuestamente definidos, la descodificación de los textos representa un gran reto. El territorio es inmenso. Ya ha sido explorado por Aristóteles y sus sucesores que trataron de dividir el discurso (no mimético) en unidades que se incrementan, desde la frase hasta las grandes partes de la dipositio, pasando por el "período" y el fragmento (ekphrasis descriptio) (Barthes "La lingüística" 67). Más tarde la escuela formalista rusa, Jackobson, y por supuesto, Lévi-Strauss que impulsó primordialmente el análisis estructural de los mitos. Sin embargo, los postulados teóricos tienen la ventaja de evitar el excesivo dispendio de energía interpretativa, ya que si bien las interpretaciones 
de un texto pueden ser infinitas, no son todas buenas, y aunque no sepamos cuáles son las mejores, podemos discernir mejor las que son inaceptables. Por lo tanto, si abordamos las novelas analizadas en esta tesis dentro de una perspectiva semejante, sea cual fuere la opinión al respecto, habrá que convenir en la siguiente distinción propuesta por Todorov:

La relación entre literatura y lenguaje está lejos de ser simple: ambas entran, al mismo tiempo, en una relación de semejanza (de substitución) y de contigüidad (de participación). ¿Es posible que el lenguaje sea un modelo del sistema literario puesto que a la vez forma parte de él? Pero la situación se torna aún más complicada si se tiene en cuenta una tercera perspectiva: no ya conocer la literatura a través del lenguaje, sino explorar la esencia del lenguaje a través de todo cuanto nos enseña la literatura. (Todorov Literatura 15)

Al igual que Todorov, corresponde questionarse ¿No es natural que la literatura, que utiliza la técnica de ciertas formas del lenguaje, se vuelva hacia la lingüistica para iluminarla, como ilumina el psicoanálisis y la sociología de las culturas? Como señala Barthes, durante mucho tiempo 
hubo resistencias a la conjunción de la lingüística y la literatura. Esas resistencias se deben al estatuto mismo de una y otra disciplina en nuestra sociedad. La obra literaria definida como lenguaje habría significado ofender su valor humanista, negar o disminuir su poder realista y poético ("Lingüística y literatura" 34).

La caracterización de la palabra literaria, y dentro de la literatura, la peculiaridad de la palabra dentro de los diferentes géneros literarios ha sido una preocupación de los formalistas rusos. Estos se preocuparon esencialmente por la dimensión filosófica del lenguaje humano, considerando la estrecha relación que se produce entre lengua y pensamiento. Los formalistas fueron conscientes de la peculiar dimensión de la literatura en cuanto a no fijar verdades absolutas, a carecer de certeza irrevocable, por eso reflexionan sobre el lenguaje con la prevención de que todas las observaciones formuladas pueden estar sujetas a posibles correcciones. Al mismo tiempo, debido al interés de los formalistas por la poesía, recurren a las categorías de la lingüística en el estudio de la lengua. Esto contribuyó a que la síntesis de sus planteamientos fuera luego recogida por otras posturas críticas. Es por eso que el hilo del pensamiento formalista nunca perdió su vigor a pesar de haber sido eliminado por 
Stalin en 1930. Su recuperación fue posible no sólo en Europa--como fue en la teoría lingüística checa a través de Roman Jakobson y luego en París, donde por mediación de Claude Lévi-Strauss, contribuyó a la creación del estructuralismo en los años 60--, sino también en Estados Unidos donde ejerció gran influencia en el New Criticism. Sin embargo, la contribución más significativa de los formalistas rusos fue su influencia en Mijaíl Bajtín. Bajtín, uno de los más importantes críticos del siglo XX, participó en los años veinte activamente en las polémicas con que el formalismo se enfrentaba a la ideología estalinista. El teórico ruso parte de la idea de que todo Io que el hombre hace en la cultura se traduce en la esfera del lenguaje. Al igual que los formalistas, buena parte de su pensamiento se articula sobre el valor del lenguaje como naturaleza activa y dinámica. Sin embargo, paradójicamente, Bajtín construye una crítica formalista para desmontar ideas formalistas; por ello, señala que estos teóricos han partido de un postulado equívoco al pretender delimitar la esencia del lenguaje literario. Los formalistas, al limitarse a cuestiones lingüísticas --como harían más tarde los estructuralistas-- desechan los conceptos esenciales con que habría de articularse una visión estética. Bajtín pretende quebrar el estrecho marco lingüístico--morfológico 
que limitaba a las investigaciones formalistas, desplegándolas hacia una dimensión antropológica y social. Al hablar de los enunciados, indica que la lingüística sólo ve en ellos un fenómeno de la lengua, y sólo los relaciona con la unidad de la lengua: en ningún caso con la unidad del concepto de la práctica de la vida, de la historia, del carácter de un individuo. En este sentido, la reflexión sobre el lenguaje que puede contribuir al estudio de la caracterización del texto literario se delínea en Bajtín como "metalingüística", puesto que no se ocupa de la relación entre la lengua como código y el texto, sino de las relaciones de los actos de palabras, los textos, de los géneros del discurso.

Bajtín enfatizó la importancia del lenguaje como agente liberador y desestabilizador de la autoridad. El enfoque bajtiano está basado en un lenguaje libertario y contestatario que relaja o ridiculiza todo lo que es rígido o serio, subvirtiéndolo. Este fenómeno que el teórico ruso denominó "carnavalización" tiene como común denominador la subversión de la retórica del poder, la burla, el sentido humorístico con matiz irónico en el lenguaje popular, así como el tratamiento dialógico de los códigos del lenguaje. El discurso carnavalesco popular es ambivalente y trasgresor frente a la unívoca cultura oficial. También 
existe una oposición entre el lenguaje popular y el lenguaje arbitrario del poder (dialogía / monología). En esta perspectiva, la explicación del discurso se busca fuera del mismo discurso, fuera de la psique individual. Todo discurso es expresión, no de un interior que se exterioriza, sino de un exterior que se interioriza con las relaciones sociales, desde el momento en que el individuo recibe de un determinado ambiente social la ideología de la que está hecha su conciencia.

Estas observaciones resultan oportunas al analizar el protagonismo del lenguaje en las novelas de Goytisolo y Valdés como vehículo desestabilizador de los discursos de la autoridad. El análisis bajtiniano resulta especialmente apropiado y se corresponde con las determinadas condiciones histórico-sociales, con la hegemonía, con la fuerza de la ideología dominante del contexto cultural en donde se desarrolla la novelística de los escritores que analizaremos en los próximos capítulos. Según Bajtín, la lengua es algo inseparable de su dimensión social, por 10 que toda obra literaria es sociológica de manera inmanente, y su mérito artístico se debe en parte a su capacidad para incorporar y reproducir la variedad discursiva de una época. Igualmente, los recursos del texto carnavalizante, tales como la estrategia de presentar los elementos 
subversivos del lenguaje, e invertir la voz de la autoridad, se expresan y resultan perfectamente adecuados para los propósitos estéticos y políticos de ambos autores. Según Bajtín, la literatura se introduce en el laboratorio social en el que las ideologías se formulan. La noción de la ideología bajtiniana indica las diferentes formas de la cultura, los sistemas sobrestructurales, como el arte, el derecho, la religión, etc., pero también los diferentes sustratos de la conciencia individual, desde los que coinciden con la "ideología oficial" a los de la "ideología no oficial" a los sustratos del inconsciente, del discurso censurado:

La novela es la variedad social de lenguas artísticamente organizada; a veces es un plurilingüísmo y una polifonía individual [...] El discurso autorial, el lenguaje de los narradores, el habla de los héroes, sólo constituyen esas unidades compositivas fundamentales con ayuda de las cuales la diversidad de lenguas se introduce en la novela; cada una admite una diversidad de voces sociales y una variedad de nexos y correlaciones entre ellas (siempre dialogizadas en uno u otro grado). Estos nexos y correlaciones especiales entre las 
opiniones y los lenguajes, este movimiento del tema por los lenguajes y hablas, su fraccionamiento en las corrientes de la diversidad social de lenguas y su dialogización, constituyen la particularidad fundamental de la estilística de la novela. (Problemas literarios 87)

Estos planteamientos de concebir la enunciación como parte de una relación social e histórica concreta, establecen un punto de encuentro con el pensamiento de Goytisolo y Valdés, que tanto se aleja del logocentrismo. Ambos autores, mediante un lenguaje provocador, contestatario y refutador, plantean la relación existente entre poder y escritura. En Goytisolo, se manifiesta como una reescritura delirante y derivante de los mitos sobre los que se basa la España tradicional: el estoicismo, el caballero cristiano, la educación del espíritu nacional, la religión católica, entre otros. Como se verá más adelante, en las novelas de Zoé Valdés, su universo se inscribe dentro de un registro literario subestándard, llevando en ocasiones el discurso a los límites del paroxismo. Un elemento importante en la narrativa valdesiana es la parodia y la risa, que al igual que la carcajada carnavalesca bajtiana, es de carácter ritual, liberador y 
catártico. Como ocurre en los textos críticos de Bajtín sobre François Rabelais, donde se expresa la cultura cómica medieval-renacentista popular, la serie de obscenidades sexuales presentes en las novelas de la escritora cubana destruye la jerarquía de valores establecidos. Lo hace creando nuevos contactos entre determinados estratos sociales y el lenguaje popular del cuerpo, el cual posee abundantes términos y expresiones de significado valorativo para destronar el orden de la ideología oficial. Del mismo modo, la libidinosidad de su discurso posee también su polo positivo en ese contexto, ya que la grosería y depravación del hombre es el reverso del ideal ascético que rebajaba la esfera sexual, como ocurre en la novelística de Goytisolo. Desde esta perspectiva, el discurso de la ideología no oficial deja de ser un discurso individual, privado, para convertirse en este caso en un discurso público ampliamente socializado, en un discurso político-cultural.

Para Bajtín, el lenguaje no es solamente instrumento de significado, sino instrumento de significación, de constitución de experiencias individuales, de los procesos mentales que, por lo tanto, como los signos que emplean, son también sociales. El teórico ruso concibe la enunciación como parte de una relación social e histórica concreta, lo cual nos remite a las observaciones sugeridas 
anteriormente en el primer capítulo de este estudio, donde partimos de las ideas de Frederick Jameson sobre la forma en que en los textos literarios subyace un "inconsciente político" y experiencias sociales que están íntimamente ligados al texto. El "inconsciente político" de Jameson se corresponde con los conceptos del discurso "consciente" y el discurso del "inconsciente" de Bajtín. El discurso del "inconsciente" se distingue por un contenido e ideología diferentes. Si el "inconsciente" es un lenguaje, como subraya Lacan, entonces en principio el inconsciente no es diferente de la conciencia, sino que se coloca fuera del lenguaje, ni siquiera puede estar fuera de la ideología. En este sentido, en Freudismo se observa que el "inconsciente" de Freud se identifica con la ideología no oficial, más concretamente con el discurso que la ideología oficial censura. ${ }^{3}$

Bajtín usa el término "ideología" en un sentido que es compatible con las diferentes definiciones que el término asume actualmente. Es decir, los hilos ideológicos sirven como trama de todas las relaciones sociales: desde las cotidianas hasta las relaciones políticas. La ideología es un sistema de concepciones que está determinado por los intereses de un determinado grupo social, y en base a un sistema de valores condiciona actitudes y comportamientos. 
Por todo ello, se puede decir que el individuo irreductiblemente está condicionado por su entorno social, y por ese motivo el lenguaje verbal no está desarticulado del mismo. El lenguaje ofrece uno de los mejores vehículos para comunicar por ser el principal material sígnico de la conciencia, y como tal, acompaña y comenta todo acto ideológico. Desde este punto de vista, se podría hablar de la omnipresencia del lenguaje en todo lo que atañe a una cultura: todos los signos en una determinada cultura están introducidos en el discurso.

Como señala Kristeva en su libro Le langage, cet inconnu, toda ideología impone su discurso, y esto explica por qué toda clase dominante quiere dominar y controlar las formas de difusión del lenguaje por medio de la prensa, la literatura, sus oradores, y censura cualquier otro tipo de lenguaje que esté en desacuerdo con el discurso hegemónico (284). El "Relato Oficial" se construye como el discurso que requiere suprimir la experiencia de desplazamiento, la conciencia de fragmentación o todo aquello que ponga en tela de juicio su naturaleza monolítica. Siguiendo esta línea de pensamiento, se pudiera afirmar entonces que para construir una identidad nacional es preciso, como subraya Kristeva, construir un discurso de la nación: 
Toute caste ou classe dominante a su exploiter la pratique du langue, et avant toute la pratique oratoire, pour consolider sa suprématie[...] La façon de parler, comme on dit communément, est loin, d'être indifférente au contenu de la parole, et chaque contenu idéologique trouve sa forme spécifique, son langage, sa rhétorique [...] On comprend donc pourquoi c'est une loi objective que toute information sociale s'accompagne d'une transformation rhétorique, que toute transformation sociale soit en un sens et très profondément une mutation rhétorique. L'exemple de la Révolution française est à cet égard très frappant. (279)

Las transformaciones lingüísticas que ocurren durante los grandes procesos políticos y su impacto en el lenguaje guardan relación, como ya se ha explicado anteriormente en el primer capítulo, con los regímenes totalitarios, que para legitimar su "verdad", recurren a los discursos totalizadores. Es sabido que durante el nazismo la dictadura hitleriana ejerció un férreo y sofisticado control sobre el habla de los alemanes. De igual forma, el interés de Stalin por la lingüística rusa es otra evidencia que apunta a la importancia que el totalitarismo concede al 
lenguaje. Un régimen simbólicamente hermético, como el totalitario, ejerce su dominio por medio de las palabras. De ahí que produzca algunos términos y calificativos humillantes que intentan exacerbar el odio al opositor. Es harto conocida la nomenclatura peyorativa ideada por el castrismo para denigrar a disidentes y exiliados: gusanos, mercenarios, mafia, escoria, etc. Este autoritarismo lingüístico no sólo combate significados peligrosos, sino que intenta deslegitimar aquellas palabras que crean un campo semántico positivo para la crítica del régimen.

La trilogía Señas de identidad, Reivindicación del conde don Julián y Juan sin tierra, por los usos que en dichas obras se hace del lenguaje (deformándolo y destruyéndolo), se posicionan en un lugar negativo frente al Estado, teniendo en cuenta que el anquilosado lenguaje castellanista en la sociedad franquista es un pilar de las glorias de España. ${ }^{4}$ Como es sabido, durante el franquismo el modelo lingüístico está sacralizado y es vía para la enseñanza del canon moral, cultural e ideológico que lucha por mantener una unidad casi robótica de las conciencias de los ciudadanos españoles de esa época. La trilogía goytisoliana muestra una obsesión por el discurso, por una sintaxis no tradicional que intenta reformar el referente y reconstruirlo. Son textos en los que se da más énfasis al 
lenguaje per se que al lenguaje intelectual. De igual modo, aunque con algunas características diferentes, La nada cotidiana y Te di la vida entera, alteran el español estándar del discurso oficialista con un léxico subestándar, donde la desnudez de la palabra se convierte en un instrumento subversivo esencial, inscribiéndose como un arma frente a esa moral representada en el lenguaje hegemónico.

Muchos estudios críticos sobre la novelística de Juan Goytisolo y Zoé Valdés abordan el aspecto lingüístico, ya que éste constituye uno de los rasgos más característicos de estos escritores. Hay que reconocer que a pesar de que a partir de Señas de identidad el proyecto narrativo de Goytisolo se caracteriza por la disolución del lenguaje y de las formas narrativas tradicionales, no es menos cierto que el dominio lexicográfico del castellano, el capital semántico y su maestría estilística, lo distinguen de otros escritores españoles de la posguerra. Sin embargo, paradójicamente, desde Señas de identidad, y, específicamente, en La reivindicación del conde don Julián, el escritor barcelonés instaura una despiadada y beligerante descomposición discursiva donde quiebra la semántica, fuerza la sintaxis y contamina todos los niveles del español escrito, utilizando como herramienta, 
precisamente, la lengua de Castilla. ${ }^{5}$ Este interés por socavar el código lingüístico imperante es tan acusado, que el propio Goytisolo ha reflexionado sobre su proyecto narrativo, tanto en ensayos como en entrevistas donde expresa con su usual ambigüedad su postura respecto al uso del lenguaje casticista: "Nunca he pensado abandonar una lengua tan hermosa como la española por ninguna cosa. Estoy dispuesto a abandonarlo todo pero no el idioma al que he servido desde que tengo uso de razón. No se me ha ocurrido abandonar jamás ese idioma" (Ruiz Lagos 67).

Esta actitud ambivalente del escritor puede interpretarse como una relación de amor-odio hacia su lengua, ya que ha manifestado en repetidas ocasiones su aversión contra la Real Academia como legisladora de la corrección del idioma y como uno de los pilares que sustenta el lenguaje literario. Goytisolo plantea romper con la sobriedad del lenguaje de esos escritores los cuales el canon literario español estima como quintaesencia del buen decir. Según ha expresado, considera que éstos han perpetuado una prosa "cadavérica", un lenguaje petrificado y embalsamado por siglos y siglos, el cual, a su parecer, es un "excremento idiomático", y donde se encuentra como el más claro ejemplo la Generación del 98, exceptuando a Valle Inclán (Gil-Toja 79) . 
Es interesante la opinión de Goytisolo sobre Valle Inclán. Goytisolo ve al autor de Luces de bohemia como un escritor que rechazó con fuerza el lenguaje y las tradiciones establecidas, quien tuvo en sus esperpentos una actitud iconoclasta y devastadora, contraponiendo la imagen de la España castiza y guerrera, de sus compañeros de generación, a la de una España que era la deformación grotesca de la civilización europea (Ruiz Lagos 54). De igual forma se ha expresado sobre Luis Martín Santos, quien en su opinión fue "el primer novelista que arremetió contra el lenguaje rancio y embalsamado de los epígonos del 98 y [...] emprendió su desacralización, simultáneamente a una brillante reivindicación del 'discurso'" (Gil-Toja 75).

La crítica literaria ha considerado que el realismo es inherente a la literatura española, por el hecho de que ha predominado casi siempre a lo largo de los tres últimos siglos. Por esta razón, varios críticos han afirmado que Goytisolo es el primer escritor peninsular de la posguerra que emprende una total renovación en el lenguaje y rechaza los viejos usos lingüísticos en cuanto substratos portadores de determinados valores culturales. Es importante señalar, como ha afirmado Carlos Fuentes, que los cambios experimentados en el lenguaje de la narrativa 
goytisoliana se deben en gran medida a su acercamiento a la narrativa latinoamericana asociada con el "boom": De esta manera, Goytisolo emprende la más urgente tarea de la novela española: destruir un lenguaje viejo, crear uno nuevo y hacer de la novela el vehículo de esta operación. Su obra se convierte así en el puente que une a dos fenómenos literarios de idéntico signo idiomático aunque de actitud radicalmente opuesta ante ese signo: la novela española y la novela hispanoamericana.

A pesar del acercamiento de Goytisolo a escritores de la nueva novela latinoamericana tales como Cortázar, Carlos Fuentes, Cabrera Infante y Severo Sarduy, que se proponen en su escritura destruir el lenguaje para reconstruirlo de nuevo, no es menos cierto la influencia que ejercen en Goytisolo, durante su permanencia en Francia, el estructuralismo y el nouveau roman. El propio autor de Reivindicación se ha referido en varias entrevistas a la influencia ejercida por las teorías del lenguaje de la escuela estructuralista agrupada en torno al Círculo Lingüístico de Praga, Barthes y Kristeva, entre otros. Se siente particularmente atraído por la importancia que ponen éstos sobre el signo y no sobre la cosa representada. Un 
ejemplo de cómo se valora el influjo de estos teóricos en la narrativa goytisoliana lo ofrece Le Vagueresse:

L'écriture de Goytisolo est influencée à présent par les modèles du roman latino-américain (mais qu'il influence à son tour), du structuralisme français, du groupe "Tel Quel", avec la création d'une écriture intertextuelle, selon la formule analysée par le linguiste Emile Benveniste et la linguistique contemporaine. Goytisolo dit luimême volontiers qu'il a suivi les travaux de la nouvelle critique française et de penseurs de la langue et de la littérature comme Tzvetan Todorov, Roland Barthes, Gérard Genette et les revues comme Communications ou justement Tel Quel. (135)

Estas nociones acerca de las diferentes corrientes literarias de los años sesenta le sirvieron al escritor barcelonés para efectuar una total renovación estilística en su escritura, y son de primordial importancia al rastrear las influencias que explican los cambios en la literatura peninsular a partir de Señas de identidad. Es por eso que Goytisolo se distingue de sus coetáneos por ser sin dudas el que ha tenido la actitud más beligerante ante la lengua; por ser el más abarcador, cosmopolita y 
universal al ir más allá de las fronteras geográficas y por encima de las limitaciones regionales.

Por su parte, Zoé Valdés marca un hito decisivo en la literatura cubana escrita por mujeres al valerse de un registro lingüístico subestándar, pletórico de dialectismos atribuidos a las capas menos instruidas de la sociedad. La nada cotidiana y Te di la vida entera están plagadas de vocablos del argot habanero posrevolucionario. La jerga delictiva del personaje de Yocandra en La nada cotidiana es una apropiación de una realidad socio-lingüística verídica, fiel a la ciudad, a la cultura y al tiempo histórico en que se desarrolla la trama de la novela. La escritora cubana afirma que trató de corregir La nada cotidiana proporcionándole una higiene al lenguaje, pero le fue imposible:

I changed f---ing to making love and so on. Then I read it and I realized the novel had lost all of its strength, all of its pain, the violence the lies within the protagonist. I had softened Yocandra, and that in turn, had softened the action. The conflict demanded those strong words. They were necessary, so I left them. (Santiago 3I) 
Valdés aporta datos para la interpretación de su quehacer literario a través de múltiples entrevistas donde afirma que el explícito contenido sexual de sus novelas no es intencional, como tampoco lo es el lenguaje crudo y visceral representativo del ámbito sociolingüístico imperante. La escritora define a Cuba como un país "desmoralizado y degradado", y, según ella, sus personajes son la versión fidedigna del verdadero "hombre nuevo" creado por la revolución en su proyección al nuevo orden social cubano, de ahí que el comportamiento lingüístico de sus personajes responda a esa realidad. Como ha señalado, "si se compara mi obra con lo que escribió el Marqués de Sade, cuya obra es más referencia social y política de una época, que sexual, pues estoy en pañales" (Hernández Cuéllar). Esto guarda relación con las afirmaciones de Kristeva, quien señala que la Revolución francesa no solamente se apoyó en el inmenso trabajo literario innovador que se operó en la lengua a través de las obras de Voltaire, Diderot y Sade, sino que preconizó un cambio en el vocabulario: « On pourrait suivre l'éclosion et la marche de la Révolution française à travers l'éclosion et la marche d'une nouvelle rhétorique, d'un nouveau style qui a ébranlé la langue française du XVIIe au XVIIIe siècle pour aboutir à la phrase de Robespierre" (Le langage 279) . 
Las ideas de Kristeva en relación con el contexto social francés, coinciden con la revolución a nivel lingüístico desarrollada en la Cuba posrevolucionaria. La causa histórica de muchas de las deformaciones lingüísticas se produjo a raíz del proceso revolucionario en 1959. Tras el éxodo masivo de ciudadanos pertenecientes al sector educativo, la educación sufrió graves consecuencias, lo que obligó a situar en las aulas a muchos maestros que no eran precisamente patrones de conducta lingüística ni tampoco de conducta social debido a que se cambió el civismo por la moral comunista. El maestro, como todos los individuos en una sociedad tal, no puede pensar y actuar como un ente particular; no tiene otra escala de valores que la impuesta por el régimen, la cual sólo responde a una obediencia ciega a la revolución y a su máximo líder. ${ }^{7}$ Fidel Castro contempló la educación como el factor fundamental para lograr la completa reconstrucción de la sociedad cubana. Un estudio titulado La educación en Cuba: pasado, presente y futuro muestra que:

En mayo de 1961, Castro declaró que todas las escuelas privadas quedarían nacionalizadas. Muy pronto la ideología comunista caló todo el plan de estudios. Nuevos planes de clases, un patrón nuevo para el plan de estudios y libros de texto 
se crearon con el objetivo de inculcar la ideología marxista-leninista en los estudiantes desde los círculos infantiles hasta los claustros universitarios. La meta fundamental del sistema educacional era la formación de una sociedad comunista. De hecho, la Constitución Cubana de la actualidad, promulga en el Artículo 38 que, el Estado... fundamenta su política educacional y cultural en la concepción científica del mundo, desarrollada y establecida por el marxismoleninismo..., y tiene como objetivo la promoción de la educación comunista de la nueva generación... El artículo 39 establece que la educación de los niños y jóvenes en el espíritu comunista es la responsabilidad de toda la sociedad. (17)

Es importante señalar que los comienzos de la revolución cubana se produjeron bajo una campaña orientada a extinguir los valores de la sociedad burguesa, entre los que contaban las expresiones del lenguaje. Hablar correctamente era percibido como una conducta aburguesada, una forma de perpetuar los patrones abolidos. Los estudios sociolingüísticos realizados en Cuba dentro de un enfoque revolucionario corroboran este planteamiento: 
Con el triunfo de la Revolución en 1959, se hacía un brusco rechazo a toda una serie de costumbres y hábitos, entre los cuales no era menos importante lo lingüístico. La tendencia a eliminar palabras y frases revestidas del "picuísimo" [cursilería] burgués y pequeño burgués se acentuaba más, en la medida en que estas clases daban sus últimos estertores. La democratización del lenguaje, como parte de un sistema total de democratización en todos los órdenes permitió inconscientemente el afloramiento de la vulgarización, fenómeno que hoy día realmente amerita una atención especial por su carácter negativo y empobrecedor de nuestra lengua nacional. (Paz Pérez 33)

Es irónica esta alusión a la "democratización del lenguaje" y la "democratización en todos los órdenes", cuando la democracia es totalmente desconocida en Cuba como dan fe múltiples estudios existentes sobre el tema. Según Paz Pérez, en la sociedad socialista cubana apenas puede hablarse de una jerga delincuencial, debido a la disminución de la actividad delictiva. Sin embargo, el lingüista cubano admite que el lenguaje jergal no ha tenido una total extinción a causa de ciertos elementos 
antisociales, grupos automarginados, que se caracterizan por actitudes negativas con respecto al trabajo, la cultura y las normas de convivencia social. Por lo tanto, según el sociólogo cubano, cualquier indagación sobre este fenómeno debe estar enlazada indisolublemente con el análisis de la formación económica-social que le dio vida. De acuerdo con este estudioso del español hablado en Cuba, "el socialismo no puede acabar de inmediato con todos los vicios de la vieja sociedad. No se puede menos de recordar que el socialismo, según dijera Marx, encierra "manchas" del capitalismo, de cuyo seno ha surgido" (53).

Lo cierto es que a partir de la instauración del castrismo se producen notables cambios, no sólo en el código lingüístico vulgar, sino en la articulación fonética del español hablado en Cuba, que a pesar de que existían en la época prerrevolucionaria, se incrementan desmesuradamente durante este período. ${ }^{6}$ Las dificultades son tanto de pobreza de vocabulario, articulación y concordancia, como de desconocimiento absoluto de los patrones de conducta lingüística establecidos. Por ejemplo, vocablos tales como "señor", "señora" y "señorita", han sido substituidos por "compañero" y "compañera". Otro factor importante ha sido la crisis económica, la cual ha provocado también notables cambios 
en el habla popular, especialmente a partir del "periodo especial", que se manifiesta en una utilización desmesurada de códigos lingüísticos vulgares por parte de amplios sectores de la población. Como resultado, las jergas marginales han pasado a todos los estratos sociales que integran la sociedad socialista cubana.

Las observaciones anteriormente expuestas, explican la apariencia de oralidad en la narrativa valdesiana, sobre todo en La nada cotidiana y Te di la vida entera. ${ }^{8}$ Uno de los elementos que se destacan en la escritura de Zoé Valdés es una auténtica situación de trasmisión oral, donde el lector tiene la sensación de estar escuchando, más que leyendo el texto al que se enfrenta. Al registrar la oralidad cotidiana de su entorno, que es la forma más directa, espontánea y natural, e incluirla como elemento estructurante en una totalidad narrativa, la autora toca más directamente al receptor. La inclusión de este material en su escritura tiene el valor de un registro testimonial; su narrativa es una apropiación y representación de la realidad cubana. Por lo tanto, de forma paralela a la búsqueda de lo oral en su narrativa, la autora manifiesta protestas y vindicaciones, ampliando la trayectoria del signo desde lo exclusivamente lingüístico, hasta un trasfondo ideológico. 
Profundizando en esta vía de análisis, diremos entonces, como Saussure y los estructuralistas (cf. LéviStrauss), que la esencia del lenguaje está contenida únicamente en el discurso "viviente" (parole), el que está cambiando siempre. Al priorizar el discurso "viviente" 0 la "oralidad" y su diversidad discursiva, se enfrenta a los discursos oficiales o del poder donde las palabras tienen un solo peso específico, unidireccional. Esta reflexión abre paso a los postulados de otro estructuralista, Roland Barthes, uno de los primeros investigadores académicos que se atreve a estudiar la cultura contemporánea basada en los discursos de Saussure y Lévi-Strauss. De Saussure parte la necesidad de considerar la lingüística como un sistema que se encuentra en la práctica humana dotado de un determinado significado. Sus concepciones estructuralistas giran alrededor de la consideración de la "lengua" (langue) como sistema común, como aspecto social del lenguaje, y del "habla" (parole) como realización individual de este sistema. De Lévi-Strauss, Barthes toma ciertos presupuestos antropológicos, especialmente los referentes a la mitología, donde el antropólogo insiste que el mito es un lenguaje. ${ }^{9}$ De hecho, el lenguaje es el tema que estudia Barthes; rebatiendo, particularmente, la presunción de 
Saussure de que el signo es siempre un convencionalismo histórico y cultural.

Roland Barthes nos dejó en sus Mithologies una reflexión sobre algunos mitos de la vida cotidiana francesa de los años cincuenta. En la primera parte del libro se analizan varios mitos en el contexto francés, y en la segunda parte se presenta el marco teórico que define y desarrolla el análisis semiológico del mito. Barthes se sirve del método de Lévi-Strauss para proponer, por primera vez, una especie de "gramática" con la que poder describir el sistema de significados sobre el que se asientan los mitos. Al igual que Lévi Strauss, para Barthes el mito es lenguaje $y$, "since myth is a type of speech, everything can be a myth provided it is conveyed by a discourse" (Mythologies 109). En este sentido, el mito, tal como lo usa Barthes, es sinónimo de ideología. La ideología promueve los valores e intereses de los grupos dominantes en la sociedad porque:

Detrás de este criterio existe un impulso político: los signos que se presentan como naturales, que se ofrecen como la única manera concebible de ver el mundo son por eso mismo autoritarios e ideológicos. Una de las funciones de la ideología consiste en "naturalizar" la 
realidad social, hacerla aparecer tan inocente e invariable como la Naturaleza misma. La ideología busca convertir la cultura en Naturaleza, y el signo "natural" es una de sus armas [...] En este sentido, la ideología es una especie de mitología contemporánea, un campo que se ha purificado de toda ambigüedad, de toda posible alternativa. (Eagleton 164)

Esta definición de los mecanismos de los que se vale la ideología es particularmente relevante en Mythologies. Común a la comprensión del mito en Barthes se encuentra la noción de una realidad socialmente construida, la cual se entiende como "natural", que proviene de lo interno del significante y no como algo intencional e histórico. ${ }^{10}$ Los valores y opiniones de una clase social especifica se sostienen históricamente y socialmente como "verdades universales". Desafiar esta "naturalización" y universalización es inaceptable por carecer de bon sens, y por lo tanto, se excluye de cualquier consideración seria. Según Barthes, el lenguaje encrático (el que se produce y se extiende bajo la protección del poder) es un lenguaje de repetición ya que todas las instituciones oficiales son "máquinas repetidoras: las escuelas, el deporte, la publicidad, [...] repiten siempre la misma estructura, el 
mismo sentido, a menudo las mismas palabras: el estereotipo es un hecho político, la figura mayor de la ideología" (El placer 67). Siguiendo el planteamiento de Barthes, se puede inferir que el mito significa el mundo del modo en que lo desea el orden dominante. El mito visto desde esta perspectiva reafirma los valores y principios del poder, legaliza el orden de ese discurso. Su mensaje no está dirigido a la interpretación individual, sino a una masa amorfa que el emisor pretende restringir y uniformar. Va en busca de la formación y manipulación de una conciencia colectiva, convirtiendo a sus miembros en obligados receptores de mensajes.

En ese encuadramiento donde se desarrolla el discurso mítico, según el enfoque de Roland Barthes, el discurso desmitificador sería entonces una forma de "metalenguaje", una reescritura que se apropia de la realidad mitificada y revela las estructuras represivas que se esconden tras el mito: la impresión de un orden fijo e inexpugnable. El desenmascaramiento ocurre por medio de un discurso cuestionador que tiene como propósito, como afirma Barthes en un ensayo posterior, cuestionar la significación adherida al lenguaje:

It is no longer the myths which need to be unmasked (the doxa now takes care of that), it 
is the sign itself which must be shaken; the problem is not to reveal the (latent) meaning of an utterance, of a trait, of a narrative, but to fissure the very representation of meaning, is not to change or purify the symbols but to challenge the symbolic itself. ("Change" 165)

Desde este modelo, se propone que la significación se destruya, que se despoje del mito la instrumentalidad del lenguaje, de toda una serie de códigos y sistemas de convenciones. En el contexto de nuestro estudio, las novelas que analizamos se enmarcan dentro de la problemática del poder y la escritura. El discurso oficial del franquismo y el castrismo, a través de palabras que mitifican y descontextualizan, construye una realidad que pretende imponer valores y criterios para obligar al individuo a conservar las estructuras de la clase dominante que, según Barthes, se confiere a sí misma poder eterno. A modo de contraataque, Goytisolo y Valdés desmenuzan y descontextualizan a su vez el discurso centralista. Es decir, expulsan al discurso del poder del contexto en que desea colocarse. Como resultado de sus propias liberaciones y vindicaciones personales, ambos escritores deconstruyen las edificaciones mitológicas de estos sistemas totalitarios, desacralizándolos y ridiculizándolos 
por medio de un discurso desmitificador. Goytisolo destruye con medios literarios la imagen de la España mística, aristocrática e imperial. Valdés articula un discurso literario que degrada y trastoca la significación de los mitos revolucionarios y los discursos monológicos de la Revolución Cubana.

De lo analizado puede concluirse que las obras discutidas en esta tesis se incorporan, sin lugar a dudas, a la corriente deconstruccionista de la literatura. Tomamos la "deconstrucción" en su sentido derridiano: en la doble acepción de desordenar y reordenar, desmontar y remontar. La deconstrucción definida como una lectura que apunta a la desmitificación, a desenmascarar la naturaleza cuestionable de todo centro, donde categorías como el lenguaje desaparecen o resultan reconvertidas en nuevas perspectivas. La deconstrucción así entendida, no sólo cuestiona la presencia de un llamado "ser autárquico" en la que el hombre ocupa el espacio principal de referencia en un sistema de oposiciones jerarquizadas, sino que también se propone el desmantelamiento del sistema que lo sanciona. Si Derrida logró revertir gran parte del pensamiento occidental es porque partió de las teorías de Freud, Nietzche y Sassure. 
Es importante aclarar que la obra de Derrida, al igual que la de los estructuralistas y postestructuralistas, se centra en el lenguaje, y la deconstrucción muestra los múltiples estratos de sentido en que trabaja el lenguaje. Sin embargo, a pesar de los puntos comunes con el estructuralismo, el gramatólogo (teórico de la escritura) observa que tanto Saussure como los estructuralistas (cf. Lévi-Strauss) operan con una noción coloquial de la escritura. Para los estructuralistas, la esencia del lenguaje está contenida únicamente en el discurso "viviente", el cual está cambiando siempre. En la teoría estructuralista se había descrito el signo lingüístico como una entidad dual que nos permite remitirnos a un referente (el significado del signo) mediante su vehículo formal, el componente sonoro/escrito (el significante). Esa concepción del signo lingüístico postulaba una relación estable entre el significante y el significado del signo. Para Derrida esto es insostenible, y por eso acomete la tarea de socavar y desestabilizar dicho discurso. Derrida responsabiliza a Saussure por perpetuar la creencia de que existe un "logos" asentado en la presencia del ser que otorga verdad y sentido al lenguaje, de ahí la tarea de la deconstrucción de tener que deshacer esas ilusorias presencias de una verdad incierta. La deconstrucción 
derridiana irrumpe en un pensamiento de la escritura, como una rescritura de la escritura, que por lo pronto obliga a otra lectura: no ya imantada a la comprensión hermenéutica del sentido de un discurso, sino atenta a la cara oculta de éste. Según Derrida, el centro cesa de ser un espacio fijo y natural, y se transforma en una especie de transmisor, como todos los demás signos lingüísticos, del sentido libre e infinito de la significación. Sin centro, todo se vuelve discurso, sin un significado original los límites de la significación se extienden ad infinitum.

Ante esta profunda inestabilidad de la significación, puede surgir la siguiente pregunta, ¿es posible intervenir críticamente en un proceso continuo de refijación de la significación? La respuesta es afirmativa ya que el acto de lectura-escritura, incluido el propio, afirma la intencionalidad de controlar la significación socio-textual y de fijar su posición. Desde esta perspectiva, es posible postular que el propósito de los textos teóricos deconstruccionistas es de autorizar el proceso de posiciones "metadiscursivas" que informan ciertas significaciones socio-textuales.

El aspecto que tomamos de la empresa deconstructiva de Derrida es el que gira en torno al concepto de "estructura" y a las falsedades que ha sostenido esta noción, ya que por 
"estructura" se supone la presencia de un "centro" que otorga sentido y orden a los elementos que forman parte del sistema, impidiendo que ninguno se desvíe o alcance un desarrollo autónomo. La deconstrucción explica que no hay posición, o lo que es lo mismo, todo lo es ("el centro está en los márgenes"). Dentro de este contexto, el discurso feminista y el discurso deconstruccionista están articulados en un nuevo proceso de refijación de ciertas significaciones socio-textuales $y$, en consecuencia, con un nuevo proceso de reproducción de la ideología cultural. Este planteamiento se puede aplicar al discurso oficialista, ya que su estructura se apoya en un núcleo creado por las estructuras del poder, el cual es sustentado en creencias religiosas o mitológicas que le otorgan una verdad absoluta. Así pues deconstruir, significa destruir esas inciertas estructuras con que el lenguaje hegemónico se ha apropiado, ha cosificado, ha llenado de "centros" inexistentes,bien en la sociedad española durante el franquismo, o bien con relación al pueblo cubano durante la dictadura castrista.

En los capítulos siguientes elaboraremos un análisis detallado del discurso vindicatorio de Goytisolo y Valdés basado en las novelas escogidas para esta tesis. Por ahora nos interesa señalar los rasgos deconstructores en las 
novelas de ambos escritores, y cómo se han de estudiar en nuestro trabajo. En general, las características más sobresalientes de Goytisolo y Valdés al desmantelar los discursos autoritarios son las siguientes: 1) Las novelas estudiadas niegan cualquier totalitarismo lingüístico y proponen discursos alternativos. 2) Ambos escritores rechazan el monologismo, que implica la imposición de un único discurso. Sin embargo, asimilan estos discursos monológicos y centralizados para luego proceder a su descomposición y reconstrucción exaltando el dialogismo con su polisemia. 3) Entre los métodos más socorridos en las novelas de ambos, se encuentran la parodia y la ironía. 4) Los personajes de las novelas en cuestión, exhiben sus ansias destructoras siendo portavoces de la desmitificación. Goytisolo estructura una serie de relaciones en la novela a nivel de personajes: narradorprotagonista, protagonista-desdoblamientos de personalidades, protagonista-España y autor-lector. Valdés estructura los suyos como alegoría o metonímicos de la nación.

Ambos escritores construyen un contradiscurso que ataca la existencia de un lenguaje unívoco, de una sola comunicación oficial. De igual modo que la deconstrucción parte de la negación del privilegio posicional, las 
aspiraciones de estos novelistas es la de dar cuenta de otras posibilidades; de generar distintos discursos que se alcen frente a la voz oficial a través de la actividad liberadora del lenguaje. Por una parte, se trata de revelar la condición tropológica de ese discurso y de constituirla en base al nuevo "libre-juego-pensamiento", que se dedicará, así, a destruir los sagrados axiomas de unos núcleos de significado que no hacen más que diferir el encuentro con las categorías de ese pensamiento. Y si alguna noción puede aplicarse a los textos que analizaremos a continuación, es, precisamente, la de que no son portadores de ninguna verdad absoluta: socavan, desestabilizan, pero no proponen una verdad total sino una dispersión de significado, a la que Derrida llama en vez de polisemia, "diseminación". 
1 Para Lacan, el lenguaje está presente desde el momento mismo del nacimiento. Los conceptos lacanianos están sustentados en el lenguaje como agente constitutivo del sujeto. Lacan destacó en sus obras lo simbólico como poder y principio organizador. El orden simbólico es el del lenguaje, y el inconsciente está "estructurado como un lenguaje", lo que determina la orientación del análisis y pone de relieve la primacía de lo Simbólico. Del mismo modo, contradice la tesis de Husserl la cual postula que el significado es algo que antecede al lenguaje.

2 Idea expuesta por Michel Foulcault en Las palabras $y$ las cosas (100).

${ }^{3}$ Freudismo y El marxismo y la filosofía del lenguaje fueron libros publicados en Leningrado en 1929 bajo el nombre de Voloshinov, pero atribuidos a Bajtín. Para más información sobre el discurso "inconsciente" propuesto por Bajtín, véase Poncio.

4 Es importante señalar que durante el franquismo, la época de los Reyes Católicos es glorificada para afirmar los grandes valores de España, sobre todo el Descubrimiento de América. A ese efecto, no se debe olvidar el protagonismo del idioma durante este periodo histórico. Al publicar Nebrija su gramática en 1492, convierte a la lengua vernácula (el castellano) en una lengua fluida que refleja el discurso religioso, la poesía íntima, el relato erótico, el discurso científico, el habla de los nobles, el registro lingüístico popular, como también el instrumento colonizador, para que los pueblos que entrasen a formar parte de los dominios de Castilla pudiesen aprender su idioma.

5 Goytisolo escribe su obra en castellano; aunque en las novelas como La reivindicación (193) intercala voces cubanas, argentinas y mexicanas que ilustran esta autonomía lingüistica que inventa su propia sintaxis. El recoger los vocablos dialectales hispanoamericanos es parte del ataque al castellanismo académico. También termina Juan sin tierra --en su novela posterior, Makbara también encontramos fragmentos en árabe-- con una página en árabe, a sabiendas de que el lector no domina este idioma, y que muy pocos árabes tampoco leerán el español restante. 
6 Las características más sobresalientes del español hablado en Cuba son las siguientes:

Características fonéticas de toda Cuba

1. /y/ es fuerte y a veces africada

2. $/ \mathrm{x} /$ es un [h] débil

3. /n/ final de sintagma y palabra se velariza

4. /rr/ es desonorizado (/rr/ > [hr])

5. /l/ y /r/ finales son neutralizados

6. /s/ final de sílaba y palabra resulta en

aspiración (/s..../ > [h]

7. /s/ final de oración se elide

Características Fonéticas de regiones particulares de Cuba

1. En La Habana, /p/, /t/, /k/ intervocálicas se eliden

2. En las provincias orientales y centrales, /rr/ es velarizada (/rr/ > [x])

3. En las provincias centrales, la geminización de $/ \mathrm{r} /$ preconsonática ocurre (puerto $>$ puetto)

4. Permutaciones de $/-r-/$ por $/-1-/$.

\section{Caracteristicas morfológicas}

1. "Tú" se usa para el pronombre familiar, y muchas veces se usa cuando "usted" es más común en otros dialectos.

2. El diminutivo "-ico" se usa después de /t/ o /d/.

3. El sufijo "-ero" se usa cuando refiere a una persona de un lugar (guantanamero, habanero, etc.)

\section{Caracteristicas sintácticas}

1. Hay inversión en las preguntas cuando el sujeto es un pronombre.

2. La palabra "más" precede una palabra negativa (más nunca, más nadie, etc.)

3. En vez del subjuntivo, el infinitivo se habla después de la palabra "para" y el pronombre ("para yo entender el libro" en vez de "para que yo entienda el libro").

7 En el año 1960, sin Castro haberse declarado abiertamente marxista-leninista, el régimen erradicó las facultades del Consejo Universitario y la autonomía universitaria se suprimió de facto. En repudio a tan drástica medida, alrededor de un 60\% de los profesores presentaron su renuncia. Luego se dicta la Ley 859, la cual 
convalida la supresión de la autonomía y más tarde al final del mismo año 1960, nace la Ley 917, la que elimina la "inamovilidad de los profesores y técnicos". Acto seguido "una Junta de Profesores y Estudiantes autodesignados sorpresivamente, reorganizó la Universidad y sus Eacultades, cercenando, eliminando y modificando, sin más criterio a seguir que el político" (The Endowment for Cuban American Studies. La educación en Cuba, 35).

8 Es un lugar común en la crítica (sobre todo latinoamericana) entender que la oralidad está íntimamente vinculada a la cuestión de la identidad cultural. Sin embargo, cabe aclarar qué es lo que se entiende por oralidad. En principio, debemos hablar de una especie de copia de una oralidad supuestamente real y auténtica, objeto de estudios sobre todo de lingüistas, sociólogos y antropólogos, o, en otra dirección, de una construcción de oralidad que si bien parte de esa "oralidad real", a la vez, está remodelada y muestra una problemática presente en el texto, aunque solapada, que es constante en la literatura latinoamericana: la identidad nacional, a través de su lengua y su historia.

9 Levi-Strauss insiste en que el mito es un idioma porque tiene que ser dicho para que exista. También es un lenguaje, con las mismas estructuras descritas por saussure que pertenecen a cualquier lengua. También, el mito es doblemente específico: histórico--casi siempre surge en un tiempo pasado--y ahistórico en el sentido que su contenido es eterno. Para él, el mito histórico es "habla" (parole); el ahistórico, es "lengua" (langue).

10 Según Barthes, la relación que existe entre significante y significado se concreta en el signo. En el primer sistema semiológico, el signo es producto de la unión entre expresión y contenido. En el mito, por ser un sistema semiológico de segundo grado, lo que es signo en el primer sistema es transformado en significante. El mito se apodera de los signos de un sistema anterior y los utiliza como significantes de los signos de su propio sistema; se apropia del significante del primer sistema, por ser la expresión material del signo. 


\title{
CAPITULO III
}

\section{EL DISCURSO DISIDENTE Y VINDICATIVO EN ZOE VALDÉS}

\author{
"Tiene hambre y nada que comer. Su \\ estómago comprende muy bien que \\ debe resistir. En su isla, parte \\ del cuerpo debía aprender a \\ resistir. El sacrificio era la \\ escena cotidiana, como la nada". \\ Zoé Valdés
}

Las novelas La nada cotidiana (1995)--con nueve ediciones consecutivas--y Te di la vida entera (1996)--en su decimosexta edición--de la escritora cubana Zoé Valdés no sólo marcan un hito en la narrativa femenina cubana, sino que ejemplarizan significativamente el llamado "boom cubano" de los años noventa. ${ }^{1}$ Ambas fueron publicadas antes que las casas editoriales, librerías, periodistas y críticos denominaran así un subgénero emergente de la narrativa contemporánea cubana enmarcado, específicamente, en el denominado "período especial", etapa caracterizada por los problemas para obtener comida, combustible y dólares. ${ }^{2}$ En esta coyuntura histórica se insertan estas dos novelas, privilegiando la desjerarquización y ruptura con un discurso canonizado por más de tres décadas de rancia y forzada cultura patriarcal. ${ }^{3}$

En la década de los noventa, Cuba experimenta uno de los peores declives económicos y la más aguda crisis de valores de su historia que repercute en todas las esferas 
de la vida. En lo que respecta al ámbito literario, vemos cómo en la narrativa se produce una eclosión bifurcada en dos tendencias. Por una parte, como afirma Nicolás Padrón, director de la editorial Letras Cubanas, hay escritores que se evaden de la realidad y escriben cuentos que "pueden haber sido hechos en el siglo XVI en Inglaterra o en el siglo II antes de nuestra era en China, es decir, que no tienen un basamento histórico" (Álvarez 89). Por otra parte, emerge una vertiente en la que hay una búsqueda del ser dentro de su entorno, pretendiendo así una aproximación histórica inmediata. Padrón señala que ésta es "una narrativa donde la gente está viendo lo que está pasando desde el individuo, no desde el colectivo como tradicionalmente se ha escrito la narrativa a partir de la Revolución" (Álvarez 90). Esta tendencia desarrolló una prosa donde los conflictos colectivos, que preocupaban a la generación que escribía en el auge de la Revolución, se sustituyen ahora por una producción literaria más enfocada en los problemas individuales. Otros de los cambios que Padrón resalta como un hecho importante a finales de los ochenta y principios de los noventa es que "incluso se han incorporado las mujeres" (Álvarez 86).

La nueva literatura cubana escrita por mujeres, marginada por décadas, a finales del siglo $\mathrm{XX}$ se convierte 
súbitamente en una de las rúbricas más distintivas de la cultura literaria actual de la Isla. Luisa Campuzano ha sido una de las primeras críticas feministas que ha indagado y trazado una especie de cartografía del corpus literario femenino actual. ${ }^{4}$ Según Campuzano, a pesar de que existía una larga e importante tradición de literatura de mujeres en Cuba, ésta se había interrumpido o paralizado en los últimos años debido a que era más importante la unidad, que mostrar las diferencias de género: "Era más importante la idea de que estábamos viviendo una épica en la cual lo fundamental eran las grandes batallas militares, esos mundos tan viriles" (Grant 18). También señala que a diferencia de otras literaturas latinoamericanas, la cubana no se caracterizó en los años sesenta, setenta y ochenta del siglo XX por el desarrollo de una narrativa escrita por mujeres. ${ }^{5}$ Tampoco hubo crítica literaria de esa producción "porque por años existió una tendencia a tildar de burguesa - peligrosa a la teoría literaria contemporánea" (Grant 19). Sin embargo, a mediados de los noventa esta situación empieza a revertirse debido a que:

Grupos de académicas, escritoras, artistas y comunicadoras, con apoyo institucional o sin él, comienzan a organizarse y a imaginar programas y acciones, convencidas de la urgencia de 
intervenir con sus prácticas culturales y profesionales específicas en la azarosa contemporaneidad de la mujer cubana, para promover la asunción de una conciencia de género, otorgar mayor visibilidad a su historia y sus relaciones culturales, y reforzar por esta vía la autoestima tan necesaria en momentos de crisis e incertidumbre. (Campuzano 40)

Estos intercambios culturales les propician a escritoras e intelectuales cubanas la interacción y conexión con un mundo ajeno a su sistema académico, poniendo en evidencia cuán escasísimos o casi nulos eran los estudios sobre la mujer en este país. ${ }^{6}$ La situación de la crítica nacional era tan precaria, que en 1996 Nara Araújo--quien se ocupaba de la crítica feminista del Caribe--sólo podía decir en relación a lo que se hacía en la Isla que "todavía estaban en la fase arqueológica de recolección y rescate de textos y autoras" (14). ${ }^{7}$ Era tal la carencia crítica, que la primera y única historia de la literatura cubana de mujeres, paradójicamente, fue publicada por una escritora no cubana en 1997: Catherine Davis, autora de A place in the Sun? Women Writers in Twentieth-Century Cuba. ${ }^{8}$ Esta nueva conciencia sobre el estado deplorable de la narrativa escrita por mujeres en la 
Isla desarrolló en el país una indagación en la crítica literaria feminista, encabezada por Luisa Campuzano, Nara Araújo y Mirta Yánez. Todas ellas son profesoras de letras de la Universidad de la Habana y en el caso de esta última también narradora y poeta. Estas mujeres se han interesado no sólo en la narrativa de escritoras cubanas insulares, sino también en escritoras cubanomericanas que residen en Estados Unidos. Tal como señala Araújo:

La necesidad, que la crítica insular cubana ha hecho explícita desde los años 90, de incorporar la producción de la diáspora, aun en sus diferentes matices--exilio/emigración, inglés/español--, evidencia los cambios que el proceso de desterritorialización ha traído para la cultura insular cubana, arraigada en un unitario proyecto de nación que parte de la defensa de sus límites territoriales frente a la hostilidad del vecino del Norte, pero que ha reconocido el peso de una producción cultural fuera de sus fronteras. ("Zonas" 50)

Este reciente interés por autores que residen fuera de la Isla se observa en "Zonas de contacto: narradoras en la Isla y en la diáspora", donde tanto creadoras insulares como cubanoamericanas son reseñadas por Araújo. Su 
estudio, subraya el uso literario del español y el inglés utilizado por algunas escritoras que viven en Estados Unidos, y la "perspectiva femenina" de esos textos. El principal interés de la crítica cubana por la literatura escrita en la diáspora parece ser el dualismo cultural "el predominio de lo privado sobre lo público y el pensar en la nación en términos de identidad, discurso político e historia, nostalgia y memoria" (49). Además de las obras de las escritoras cubanoamericanas Eliana Rivero, Cristina García y Achy Obejas, analizadas por Araújo en este estudio, también se hace referencia en nota a pie de página a una larga lista de otros autores incluidos en antologías y estudios críticos publicados en Cuba. ${ }^{9}$

Es importante notar que tanto los estudios críticos de Campuzano como de Araújo se inscriben en unas coordenadas que plantean el estudio de la narrativa de escritoras cubanoamericanas y cubanas insulares desde una perspectiva de género. La temática de esta literatura se caracteriza por problemas generacionales, conflictos familiares, relaciones de pareja, orientación sexual, identidad lésbica, la marca lingüística, en este caso el inglés, aunque el escribir en ese idioma no sea una condición limitante. Sin embargo, a pesar de que se ha incorporado al ámbito crítico insular la producción literaria de 
escritores residentes fuera de Cuba, como lo evidencia el estudio "Zonas de contacto: narradoras en la Isla y en la diáspora", es interesante observar la forma en que la crítica cubana soslaya o parece ignorar aquellas obras donde existe una directa y explícita denuncia a la situación política en el país. Tal omisión se evidencia en el vacío de estudios críticos sobre una notable exponente del "boom cubano" de los noventa: Zoé Valdés, la más publicada y traducida narradora cubana, actualmente exilada en París. A pesar de que un análisis del panorama de la narrativa femenina cubana contemporánea sería incompleto sin mencionar a Valdés, hablar de ella parece representar un acto subversivo para cualquier crítico insular por ser una de las voces más inusitadas de la disidencia.

Por otra parte, en la Isla ha emergido una reciente y rica producción femenina nacional, asumida por las denominadas "novísimas": Ena Lucía Portela (1972), Marilyn Bobes (1955) y Karla Suárez (1969), entre otras. Estas narradoras, en sentido general, se abstienen de confrontar abiertamente a la dictadura castrista, aun cuando la mayoría abordan temas antes apenas tratados o considerados tabúes tales como el erotismo, la prostitución y la drogadicción. Un tema prohibido drásticamente en los años setenta, el homoerotismo, entra en la narrativa escrita por 
mujeres con Ena Lucía Portela, quien ha hecho de la identidad lésbica uno de los principales objetos de su indagación. Por otra parte, Marilyn Bobes y Karla Suárez reconceptualizan el resurgimiento de la prostitución en Cuba, con la aparición de las jineteras. ${ }^{10}$ Sin embargo, como señala Campuzano, esto se debió en parte al impacto del turismo y el deseo de comer en grandes restaurantes y pasear en automóviles lujosos, pero en realidad, de acuerdo con Campuzano, las dimensiones de este fenómeno social se han magnificado dentro y fuera de la Isla (44).

Estas autoras de finales de los noventa tematizan de modo más o menos explícito la crisis moral y social del país; sin embargo, sus textos, a simple vista, no parecen tener relación con referentes políticos específicos. Como ha señalado la crítica, "las escritoras más jóvenes por 10 regular eluden toda referencialidad al contexto social y a un ámbito que no sea el más inmediato, personal, o de grupo" (Campuzano 41). La literatura creada por mujeres desde Cuba es más bien una narrativa marcada por la experimentación y la incorporación de corrientes del pensamiento y arte contemporáneo. Estas autoras asumen un discurso de lo individual, de un autoconocimiento que permanentemente se niega o se cuestiona pero que en ningún momento transgrede las estructuras del poder abiertamente. 
El análisis panorámico de la literatura escrita por mujeres en la isla, realizado tanto por Campuzano como por Nara Araújo, nos ayuda a contextualizar mejor la obra de Zoé Valdés, quien se aleja temáticamente de sus coetáneas cubanas por poseer una prosa visceralmente crítica contra el régimen imperante en Cuba. La trayectoria de la producción cultural de Valdés comienza a mediados de los años ochenta, cuando ocupó un puesto en la UNESCO y trabajó posteriormente en la oficina cultural de la Embajada Cubana en París. De regreso a Cuba, escribió guiones cinematográficos y fue directora de la Revista de cine cubano, publicada por el ICAIC (Instituto Cubano de Arte e Industria Cinematográficos) hasta finales de 1994. Es importante señalar que Valdés ya había ganado premios poéticos, entre ellos el "Roque Dalton" y el "Jaime Suárez Quemain" con el libro Respuestas para vivir (1982); también fue finalista del premio "Carlos Ortiz", en España, con Todo para una sombra (1986) y ganadora del de "Casa de las Américas" (1988). Para entonces también había escrito Sangre azul, única novela publicada inicialmente en Cuba (1989) .

La nada cotidiana, a pesar de ser publicada en 1995, fue escrita entre el 93 y el 94, "de un tirón. Fue, como te dije hace un rato, un vómito con una rabia tremenda" 
(Santí 9). Como subraya la autora, escribía "en los años más duros del 'período especial', dentro de Cuba, dentro de mi casa, frente a una ventana desde la que veía a la gente tirarse en lanchas al mar" (Palacios 58). El manuscrito sale de Cuba en la balsa de un amigo, y otra copia con un periodista que lo lleva a Francia. El exilio posterior de Valdés en la capital francesa agudizó aún más su desbordante discurso antirrevolucionario, al poder expresar libremente lo que estaría de otra forma censurado en Cuba. Tal como ha señalado desde una perspectiva feminista Cristina Ortiz Ceberio:

De esta manera, se podría decir que la obra de Zoé Valdés aparece como un puente que combina las tendencias experimentales e ideoestéticas de las "novísimas" con la preocupación y el comentario social de la generación precedente. Lo novedoso en Valdés es, por tanto, la combinación en su prosa de experimentación formal y comentario social, aspecto último que si bien aparece en su prosa incipiente se vuelve más explícito y descarnado una vez la escritora abandona la isla para exilarse en Francia. A esa crítica social contenida en su prosa, Valdés añade otra capa de complejidad al permitir una interrogación sobre 
la inscripción del género sexual en la narración. (118)

Coincidimos con Ortiz Cebeiro en cuanto al fuerte contenido socio-político y la perspectiva erótico-feminista en la escritura de Valdés, elementos que configuran la construcción de una identidad femenina que se presenta paralelamente al discurso hegemónico. Este recurso se repite en Te di la vida entera y en otras novelas, siendo uno de los aspectos más novedosos del corpus literario de la escritora, y, al mismo tiempo, el elemento diferenciador del resto de las escritoras de su generación.

Valdés concluye las últimas páginas de La nada cotidiana dudando de la calidad literaria de la novela que acaba de escribir: "Yo sé que no será genial. No me sobrevaloro. Soy un producto semántico de pésimas maestras de español. No me sobrestimo. Tengo dudas con la construcción de frases largas, hago una choricera de palabrería superflua" (170). Sin embargo, La nada representa la consolidación como escritora de Valdés al crear una crónica ficcionalizada de la Revolución desde sus inicios hasta los peores momentos de la época posrevolucionaria. Valdés ha sabido dar como nadie el testimonio político, ideológico e histórico más desgrarrador de la realidad vivida durante "el período 
especial". El anclaje del discurso de la escritora es la realidad contemporánea cubana. Su escritura dialoga con los elementos sociales que el régimen silencia: la represión, el miedo, la censura, el desabastecimiento y escasez de los productos más básicos y las estrategias para conseguir comida o productos de higiene.

La nada cotidiana narra la historia de Patria, la protagonista así nombrada por su padre revolucionario por haber nacido durante el año del triunfo de la Revolución, y que con el paso de los años, desencantos y vicisitudes en Cuba se cambia el nombre por el de Yocandra. Estas decepciones también las experimentará Cuca, protagonista de Te di la vida entera. Patria/Yocandra representa a nivel alegórico el inicio glorioso y el proyecto utópico fracasado de la Revolución cubana. Al mismo tiempo es un personaje autobiográfico, ya que varios aspectos de su historia coinciden con la vida de la autora. Por ejemplo, Valdés, al igual que Yocandra, nace en La Habana en 1959, fecha del nacimiento de la "nueva Cuba". El heroico nacimiento de Patria-Yocandra se textualiza a través de la construcción de un discurso oficialista pletórico de la iconografía revolucionaria: el Ché, el discurso del Comandante en la Plaza de la Revolución, la bandera 
cubana y la descripción del personaje del padre como representación de los machos-héroes revolucionarios:

"-Pues mire...Me gustaría ponerle Victoria...o mejor, mejor... ¡Patria!... Patria es un nombre muy original!... isoy el padre, el padre de Patria, de la Patria! ¡Carlos Manuel de Céspedes! ¡El primero que liberó a sus esclavos! ¡Qué par de cojones...! (La nada 26)

En el capítulo tercero Patria se despoja de tan emblemático nombre y decide entonces llamarse Yocandra. Este gesto enmancipador preludia la deconstrucción discursiva con que se arremete en el resto de la novela y, como observa Madeline Cámara, es "la primera señal de que estamos ante un personaje literario que, al construirse desde la primera persona, optará por la libertad de la ficción autobiográfica para modificar su identidad femenina de un modo anticonvencional y liberador" (66). Esta estrategia narrativa de rebelarse contra la imposición del padre biológico responde también al rechazo del sistema totalitario con que el padre se identifica plenamente. Por lo tanto, al interpelar una nueva construcción de la identidad, Valdés da vida a un personaje que configura una nueva imagen de Cuba muy alejada del paraíso tropical revolucionario: 
Me despabilé con el buchito de café, me lavé los dientes, desayuné agua con azúcar prieta y la cuarta parte de los ochenta gramos del pan de ayer. He administrado muy bien el pan nuestro de cada día. Cuando hay --isi es que hay!-- lo pico en cuatro... Tengo pasta dental gracias a una vecina que la cambió por el picadillo de soya. (29)

Me voy al malecón a venderle en dólares a las jineteras la ropa que ya no me sirve, o a cambiar azúcar por malanga, malanga por habichuela, habichuela por cebolla, cebolla por arroz, arroz por leche en polvo, leche en polvo por detergente, detergente por aspirinas, aspirinas por azúcar, y así, y así, en los mercados negros y rojo, que es la mezcla de los ladrones estatales con el pobre pueblo que, por razones obvias de humanidad, para poder sobrevivir deberá delinquir. (66)

Es importante señalar las alusiones al sistema político que se inscriben en el cuerpo de los personajes. Esto se debe a la opresión que algunos de ellos, en especial Yocandra, sufren en el régimen castrista. Uno de los elementos más interesantes de los personajes de la Nada 
es que a pesar de que tienen una gran vida imaginaria son personajes alegóricos. No tienen nombres propios sino una calificación identificadora, tales como el Padre, el Traidor, el Nihilista, la Gusana o el Lince. El Traidor, el primer marido de Yocandra, es un personaje esperpéntico y metonímico de la Revolución que ejemplifica la megalomanía política de los machos-héroes revolucionarios: "un Rambo del comunismo, un machista leninista" (59). El padre también revela marcados rasgos de machismo y homofobia, representando así una extensión de la dirigencia revolucionaria. La crítica ha mencionado que los personajes valdesianos son maniqueos, caricaturescos, a lo que Valdés ha respondido: "Lo cierto es que lo hice con toda intención. Quise marcar la caricatura y el maniqueísmo de los personajes porque provienen de una realidad caricaturesca y maniquea. Eso son los personajes que produce esa sociedad" (Santí 11).

Para dibujar una joven generación en protesta y engendrar así el contradiscurso de su nada cotidiana, Valdés se sirve de El Lince, que huye por balsa de la Isla; la Gusana, prostituta legal que escapa con un turista español de avanzada edad; y el Nihilista, joven cineasta amante de Yocandra. Estos personajes refractarios articulan un discurso silenciado que expresa situaciones críticas. ${ }^{11}$ 
Sus voces, enemigas de la Revolución, son una alusión directa a hechos acaecidos o vidas que se viven en la zozobra de un día a día calamitoso, representando así a la población cubana que no tiene voz propia y no tiene otra opción que resistir esa larga condena. Son personajes, que desde sus distintos espacios de marginalización, construyen el adverso tapiz social de una isla "que queriendo construir el paraíso, ha creado el infierno" (20).

Varios críticos han destacado que en el subtexto de La nada cotidiana y Te di la vida entera se percibe la acuciante carencia económica de la Cuba de los noventa. La hiperbolización de las penurias diarias, sobre todo el hambre y la introducción de elementos escatológicos ligados a lo sexual, han vinculado la escritura de Valdés con el género picaresco. Madeline Cámara ve en La nada una actualización y reescritura de la picaresca femenina, ejemplificada en La Pícara Justina. Coincidimos con el enfoque de Cámara en relación a ciertos referentes sociopolíticos y estilísticos que se dan en el género picaresco y que tienen una representación analógica en La nada cotidiana. Una relectura de la picaresca en el contexto de la situación cubana nos remite a ciertas teorías de la recepción, especialmente la expuesta por Hans Robert Jauss. 
La teoría propuesta por Jauss intenta otorgar a la literatura una dimensión histórica. El crítico alemán plantea la integración de la literatura a la historia desde la perspectiva de la teoría de la recepción. Según Jauss, la escritura y la lectura "normales" funcionan en relación al "horizonte de expectativas" que cada lector posee. El crítico utiliza esta expresión para describir los criterios utilizados por los lectores para juzgar obras literarias en cualquier período dado. La noción de "horizonte de expectativas" señala que todo lo que se lee condiciona la lectura de nuevos textos:

A literary work is not an object that stands by itself and that offers the same view to each reader in each period. [...] A literary work, even when it appears to be new, does not present itself as something absolutely new in an informal vacuum, but predisposes its audience to a very specific kind of reception. (1200-01)

La literatura, según Jauss, es definida e interpretada por sus diversos momentos de "recepción" histórica. Esto nos sirve a la hora de indagar por qué en ciertas épocas se reactualizan y reescriben estilos y topologías surgidos en el pasado, como evidencian la nada cotidiana y Te di la vida entera. La nueva obra evoca en el receptor el 
sistema de ideas que le es familiar de textos anteriores. Es decir, la perspectiva presente siempre implica una relación con el pasado. Comprender una obra depende de las preguntas que nuestro contexto cultural nos permita plantear; y al mismo tiempo, descubrir aquéllas a las que la obra ha intentado responder en su propio diálogo con la historia en una sucesión dialéctica.

La lectura de La nada cotidiana y Te di la vida nos pone en contacto con la precaria situación política acaecida en Cuba tras el colapso del bloque comunista de Europa del Este. Esta recepción histórica nos remite a la España del siglo XVI y XVII que experimentaba de forma similar el desmoronamiento del imperio y una gran turbulencia social, justo en el momento en que se inaugura la picaresca como género novelístico. Al igual que el "boom cubano" de los noventa, el elemento detonador que inició el género picaresco en la Península Ibérica fue la hambruna rampante en que hundieron sus monarcas al pueblo español, en un afán de grandeza imperial. Por eso Menéndez Pelayo denominó la picaresca como "La epopeya cómica de la astucia y del hambre." Ese hambre atroz, referente integral del Lazarillo, impregna de igual modo el discurso en La nada cotidiana y se hace aún más intenso en Te di la vida entera: 
¡Ah, mamey, cuánta añoranza, eres sólo una

palabra para saborear en la literatura!

\section{(La nada 73)}

Sobrevivimos con el estómago encharcado o cerrado por reparación. Nada existe. Sólo el Partido es inmortal. (La nada 97)

¡UN BONIATO, SEÑORES, de pensar nada más en un boniato se me hace la boca agua! ¿Qué rayos cocinaré hoy? [...] tengo una clase de debilidad. Las tripas no me dejan ni pensar. (Te di 195) A Cuca se le ensalivan las comisuras de los labios, y sufre un leve vahído después de un concierto de tripas de su sistema digestivo, más vacío que un estadio con aguacero. (Te di 198) Saldré un rato a ver si consigo algo de jama, o por lo menos, a ver si me entretengo por ahí, caminando, y se me olvida el hambre. ( $T e$ di 196)

Estas líneas plenas de comicidad, humor y sátira prodigadas por la narradora con gran sarcasmo, permiten establecer ciertos puntos de contacto entre la parodia y la ironía del discurso valdesiano con los procedimientos narrativos utilizados por los narradores de la picaresca. En La nada cotidiana, este discurso trasgresor, subvierte la pasividad femenina mediante conscientes agresiones y 
ataques contra los códigos establecidos, convirtiendo a la novela en un alegato contra el régimen totalitario cubano. Como ha señalado Madeline Cámara y Cristina Ortiz Cibeiro, el "yo sexuado" o la inscripción del género es una instancia fundamental en la narración de Zoé Valdés. Esto es evidente tanto en La nada cotidiana como en Te di la vida entera. Ambas novelas poseen una temática común centrada en la deconstrucción de la retórica de la revolución por medio de formulaciones feministas, que prestando atención a la textura del lenguaje, buscan expresar lo que ha sido silenciado. Para ilustrar cómo se opera este discurso es preciso resaltar desde una valoración teórica las ideas de Kristeva y Derrida, para los cuales la mujer, por ser considerada la negación de lo fálico, es la sede privilegiada desde la cual es posible desjerarquizar el pensamiento falocéntrico occidental. Este postulado se cumple en Te di y La nada ya que en ambas novelas se deconstruyen las jerarquías y los binarismos del régimen patriarcal y se denuncia la maniobra impositiva que obliga a las mujeres escritoras a regirse por códigos de conducta masculinos.

La crítica derivada de la escena teórica francesa (Cixous e Irigaray) ha sabido dar una respuesta a lo que singulariza la escritura de las mujeres por 10 
distintivamente femenino, ligando el texto a una vivencia de la corporalidad. Estas ideas se hacen eco en la escritura valdesiana quien parece seguir el pensamiento enunciado por Cixous sobre el acto de escribirse con una escritura transgresora. Valdés reorganiza un discurso alternativo desde el cuerpo femenino erotizado que resiste al intento de sistematización ejercido desde el poder. Por consiguiente, el acto de escribir como diría Cixous: "no sólo 'realizará' la relación des-censurada de la mujer con su sexualidad, con su ser-mujer, devolviéndole el acceso a sus propias fuerzas, sino que le restituirá sus bienes, sus placeres, sus inmensos territorios corporales cerrados" (61). De igual modo, Nelly Richards enfatiza como modelo paradigmático una estética basada en lo corporal, de flujos libidinales tradicionalmente censurados por el modelo de racionalización masculina. (740)

El placer de la sexualidad femenina en la escritura valdesiana se inscribe en unos postulados análogos a las propuestos por Richards, de ahí el ansia y deseo de otorgar al Eros un papel fundamental en el camino hacia la desjerarquización masculina. La protagonista de La nada subvierte los estereotipos de pasividad atribuidos a la mujer y se entrega a una expresión erótica que oscila continuamente entre la deconstrucción del discurso 
hegemónico y la jouissance. Yocandra se entrega en un exorcismo carnal primero con el Traidor donde asume un rol agresivo, en vez de ser poseída, es ella quien posee: "El chilló de dolor, yo no había lubricado lo suficiente. Costó trabajo pero lo decapité"(44). Más tarde con su amante, el Nihilista, asume una postura voyeurista en la contemplación del cuerpo y el órgano eréctil masculino: "cuando el se desnudó, su cuerpo griego me dejó pasmá, boquiabierta" (141). La protagonista rompe de esta forma con el discurso que toma al hombre como sujeto observador y a la mujer como objeto observado. De esta manera, los roles de género son puestos en evidencia y subvertidos, que como nos señala Luce Irigaray: "for this ego [la afirmación del sujeto en el ámbito simbólico social] to be valuable, some mirror is needed to reassure it and re-insure it of its values. Woman will be the foundation for this specular duplication, giving man back 'his' image and repeating it as the "same"" (Wharhol 410). Valdés insiste en esa fórmula al crearse a sí misma como la imagen especular que propone Irigaray, no para devolverle al hombre su imagen, sino para romper ese discurso que toma como sujeto único al propio sujeto masculino que lo constituye. Por lo tanto, Valdés parece ilustrar en su obra las ideas sobre el placer sexual femenino expuestas por Irigaray: 
Lo que se ha mantenido como totalmente prohibido a la mujer es, por supuesto, que exprese algo sobre su propio placer sexual. Esto último se supone incluido en el 'dominio' del discurso, construido por los hombres. Pero, de hecho, el placer femenino significa la mayor amenaza de todas para el discurso masculino, dado que representa su más irreductible "exterioridad" o "exterritorialidad". (156-157)

Esta observación, que apunta hacia el papel central del cuerpo femenino en el discurso de Irigaray, en tanto que se adopta como referente prioritario, se confirma a lo largo de muchos de los textos de esta autora que quiere hacer de lo corporal femenino una especie de núcleo para un contradiscurso frente al masculino/patriarcal imperante. Esas preocupaciones feministas se ocupan de la recuperación del espacio negado a la mujer el cual es una categoría que según Nelly Richards, "debe ser permanentemente reinterpretada según la acentuación crítica que exigen las circunstancias de discursos en las que se mueve" (742). En el caso de la protagonista de La nada cotidiana, el cerco asfixiante de la ideología política que invade todo su espacio personal, actuando como yugo castrador en su calamitosa existencia, desata un frenesí sexual, un 
desenfreno como único gesto de liberación posible. De esta forma, en el capítulo ocho, cargado de fuerte contenido sexual, la escritora burla al censor "porque cada escritor tiene un policía designado" (133) y escribe un discurso explícito de crudeza sexual que linda con lo pornográfico. En las novelas de Valdés no sólo es obsceno el relato, sino la propia vida de privaciones. El cuerpo mismo de Yocandra está implicado en una definición de la identidad nacional; el mundo referencial de la Isla. La voz de la protagonista es la voz de otras mujeres que se hacen oír a través de ella; mujeres que la mayoría de las veces son silenciadas tanto cultural, como social y políticamente. En este sentido, las estrategias textuales que Valdés utiliza en su escritura se hacen eco de la apasionada exhortación de Cixous:

Un texto femenino no puede no ser más que subversivo: si se escribe, es trastornando [...] Es necesario que la mujer se rescriba porque es la invención de una escritura nueva, insurrecta lo que, cuando llegue el momento de su liberación, le permita llevar a cabo las rupturas y las transformaciones indispensables en su historia, al principio en dos niveles inseparables--individualmente: al escribirse, la 
Mujer regresará a ese cuerpo que, como mínimo, le confiscaron [...] Censurar el cuerpo es censurar, de paso, el aliento, la palabra.

A pesar de que Cixous en sus tajantes y radicales propuestas feministas se mueve ocasionalmente hacia posturas esencialistas, en sus textos sigue siendo obvio que el cuerpo femenino representa impulsos instintivos insertados en la escritura. De igual modo, según el punto de vista de Kristeva, el cuerpo aparece como goce y, en el acto de escribir, es una fuerza semiótica capaz de quebrantar al orden simbólico masculino. Estas ideas de presentar el cuerpo femenino como nuevo locus de enunciación en el texto, según Derrida, representa la estrategia más desestabilizadora, la alteración más radical del discurso dominante.

Yocandra en La Nada escribe un discurso erótico para vengarse del Traidor, su primer marido y personaje metonímico de la Revolución castrista. De igual forma, en Te di la vida entera la actividad sexual lésbica entre las amigas de Cuca transgrede el código moral impuesto y subvierte los estereotipos de pasividad atribuidos a la mujer. Valdés desestabiliza con su escritura la determinación de lo femenino a partir de una proyección esencialmente masculina. Expone la dificultad de la mujer 
en asumir su autonomía, y de que ésta--su proyección--tenga incidencia en la configuración cultural por el hecho de ser la cultura cubana predominantemente androcéntrica y esencialmente masculina, en donde las jerarquías, las categorías y los valores han sido establecidos por el varón. Psicológicamente hablando, Valdés elabora una especie de venganza contra una sociedad donde el machismo y la subyugación de la mujer son prevalentes. Este sentimiento responde a las emociones más básicas: resentimiento e indignación. Como expresa la escritora: "El dolor puedes colocarlo en otra dimensión, utilizarlo, pero olvidar... no se puede" (La Revista $\mathrm{S} / \mathrm{N}$ ). Vemos así como la venganza se presenta no como un capricho, sino como una manera dolorosa y amarga de aliviar el rencor, y el cuerpo es una de las zonas para ejercerla. Esta pasión vindicatoria es un acto de valor que surge de un sentimiento elemental de injusticia. De ahí que en el acto sexual, por la intimidad requerida, sea donde

The avenger must somehow communicate to the target the reasons for the infliction of the punishment. The relationship between the avenger and the target becomes a remarkably intimate one [...] The taking of revenge usually produces an emotional or psychological state in the avenger, 

a feeling of pleasure, a sense of accomplishment,
a high. (French 69)

Esta imagen vindicatoria ilustrada por French es uno de los aspectos resaltados a nivel metafórico en la narrativa valdesiana. El cuerpo expresa códigos sociales, se convierte en intertexto narrativizado en que habitan significados psíquicos y sociales, normas e ideales que el sujeto incorpora como categorías sociales de conducta de su interior psicológico. Como se ha indicado anteriormente, la esfera de la experiencia corporal se convierte en el territorio donde Valdés sitúa sus vindicaciones personales, como si el cuerpo erótico fuera el espejo del cuerpo político.

Debemos tener presente que a veces un escritor crea una obra porque necesita volcar en ella una serie de circunstancias personales. En ese caso, es la psicología del creador la que actúa como factor determinante y no se puede renunciar a ella. Desde el momento en que se admite que toda personalidad comporta un subconsciente, dicho subconsciente puede aflorar en la obra del escritor y manifestarse como elemento creativo. Muchos novelistas tienden a presentar en sus narraciones una serie de personajes recurrentes en los que se reflejan facetas de la personalidad del autor. Varios críticos citan numerosas 
teorías psicológicas al proponer que Fausto, Mefistófeles y Werther son proyecciones literarias de diversos aspectos del propio Goethe. En las novelas de Dostoyevski y Flaubert se manifiesta reiteradamente la proyección del autor en sus personajes. Con esto no pretendemos plantear un análisis de rasgos biográficos, ni utilizar un enfoque teórico psicoanalítico para analizar a la escritora cubana, sino resaltar la correspondencia biográfica que la obra de Valdés presenta como elemento cohesivo.

En este trabajo nos interesa explorar los mecanismos que contribuyen a la acérrima violencia textual en Valdés mezclada con un activo erotismo, concepto ampliamente aceptado en escritores de sexo masculino, pero un hecho inusitado en la literatura cubana escrita por mujeres. Como observamos en el primer capítulo, donde estudiamos los efectos de la represión en el ámbito literario, la escritura para Valdés tiene un poder redentor. Es en ella donde exorciza sus demonios y la escritora da rienda suelta a todo lo censurado y represivo. Desde una aproximación psicoanalítica recordamos que la expresión individual de la represión de la que habla Freud puede manifestarse en la literatura entre el personaje y el autor, revelando muchas veces el trasfondo ideológico del creador y su época. Estas ideas freudianas se complementan con las teorías de 
Lacan para quien el sujeto, al ser también un sujeto lingüístico, se encuentra dividido entre el "yo" que enuncia y el "yo" objeto de la enunciación. Por lo tanto, considerando los conceptos lacanianos de la importancia del lenguaje como agente constitutivo del sujeto, se infiere que la intervención en el colectivo nacional a través de la escritura, sería similar a la que se da en la formación del sujeto. Como ya se ha mencionado, las obras de Zoé Valdés se sustentan en elementos autobiográficos; mucho de lo que acontece en sus novelas tiene directa relación con su vida. Como la propia autora ha afirmado "mi lengua soy yo, está sedimentada muy hondo en mí porque es mi pensamiento" (Entrevista personal 2). De ahí el nivel agencial del sujeto femenino en su producción narrativa.

No cabe duda que la experiencia de exilio ha marcado la narrativa de muchos escritores de la Isla debido a que el destierro es un referente común en las letras cubanas desde el siglo XIX. ${ }^{12}$ La problemática de la expatriación ha marcado sin duda alguna la obra de Zoé Valdés, quien afirma que la experiencia del exilio es beneficiosa y fértil porque puede hacer "de la nostalgia un élan, un impulso creativo, para nada bloqueador debido a que el exilio saca a flote una suma de recuerdos impresionantes e imprescindibles al creador" (Entrevista 2). Como hemos 
indicado anteriormente, el exilio agudizó en la escritora la crítica hacia el régimen castrista al verse libre de publicar su obra sin la censura imperante en Cuba y poder producir un texto, en términos kristevianos, abyecto y disidente. Valdés se incorpora a la lista de escritores cubanos que desde Heredia y Martí hasta Cabrera Infante, han plasmado en la literatura la angustia de su país. Es oportuno mencionar una serie de conexiones que la crítica ha apuntado entre su obra y figuras de la literatura cubana. Sobre todo, los ecos que se perciben en su producción novelística de dos importantes escritores exilados: Reinaldo Arenas y Cabrera Infante.

Reinaldo Arenas (1943-1990), quien arribó a los Estados Unidos durante el éxodo masivo del Mariel en 1980, dio origen a una literatura subversiva y disidente de la cual Valdés es heredera. Para Arenas, la pasión dominante era el sexo, según Cabrera Infante "fue el cronista de un país regido no por Fidel Castro, ya impotente, sino por el sexo" (Mea Cuba 231). Su pansexualismo fue siempre homosexual, dejando un visión homoerótica del mundo que le tocó vivir. A diferencia de Arenas, Valdés añade un nuevo componente a su narrativa que le permite construir un discurso de la nación desde la posición de género. Sin embargo, tanto la franqueza oral de Arenas y el realismo 
descarnado de su prosa, como la furia y la rabia que domina totalmente su obra, marca un precedente en la literatura cubana que Valdés ha sabido renovar en su escritura. ${ }^{13}$

De igual modo, la mirada desde la lejanía del exilio que Cabrera Infante plasmó en Tres tristes tigres, en un intento de recuperar el espacio físico habanero abandonado, se puede percibir en Te di la vida entera. En esta novela la escritora recoge el habla del cubano del "período especial" en todos sus matices (parodia, chiste, choteo) al igual que Cabrera Infante supo recrear el habla coloquial cubana y la jerga nocturna de ciertos ambientes habaneros en los años cincuenta en Tres tristes tigres. Como la misma novelista advierte, en esta novela escribió "sobre una ciudad reecontrada en la vida y en la literatura, queriendo homenajear la obra magistral de Guillermo Cabrera Infante" ("La ciudad" 3).

La influencia ejercida por el novelista cubano sobre Te di la vida entera queda clara por medio del epígrafe tomado de Tres Tristes Tigres con que comienza la novela: "Habanidad de habanidades, todo es habanidad [...] Dos desmadres tengo yo, la ciudad y la noche". En dicho epígrafe, Cabrera Infante parodia al Eclesiastés y a los famosos versos de Martí "Dos patrias tengo yo, Cuba y la noche". El autor de Tres Tristes Tigres, con su usual 
lenguaje lúdico, deconstruye el valor semántico y la solemnidad del texto de Martí sustituyendo "patria" por "ciudad" para referirse así a la capital cubana. Tanto para Zoé Valdés como para Cabrera Infante, La Habana representa un espacio mítico que intentan rescatar en sus respectivas novelas por medio de un nostálgico recorrido a través del habla de un época, la música, los bajos fondos, los registros sociales y políticos, la intertextualidad literaria y cinematográfica. Ambas novelas están cuajadas de descripciones de la capital cubana, la cual se convierte en una maqueta donde cada autor proyecta sus esperanzas, sus deseos y sus angustias.

Cabrera Infante describe una ciudad poblada de cabarets, bares, clubs y centros nocturnos por donde transitan los cuatro personajes masculinos de su novela, atraídos por un paraíso de ocio y entretenimiento que ofrecía toda clase de placeres y diversiones, y en donde todas las fantasías eran posibles. El propósito del autor al escribir este libro era conservar para la posteridad la imagen de la metrópolis cubana, y sobre todo, la vida que bullía en ella. Su actitud, lejos de regodearse en la degradación social, como ocurre en Te di la vida entera, plantea las situaciones desde un punto de vista humorístico y desenfadado, obstruyendo el contexto sociopolitico tan 
marcado en Valdés. Su obra está basada en otras motivaciones que no se dan bajo la férula del comunismo que Valdés continúa en su novela. La obra de Cabrera Infante se circunscribe a dos décadas fundamentalmente, mientras que la de Zoé Valdés se extiende hasta mediado de los noventa.

Te di la vida entera tiene como protagonista a Cuca Martínez, campesina que llega a la capital habanera a finales de los años cincuenta, en víspera de la Revolución. Este eje estructural sirve, como en La nada, para contrastar La Habana precastrista con la postrevolucionaria. Ambas novelas poseen una temática común centrada en las consecuencias drásticas de la Revolución para Cuba, temática que al igual que La nada está inundada de acritud, humor y rabia. El espacio urbano aparece altamente jerarquizado y personificado. El aspecto encantado de "la Habana colorida, iluminada, iQué bella ciudad!" (31), de la primera parte de la novela, se convierte más tarde en la Habana "Ciudad Mortaja" de edificios cubiertos por una gruesa capa de mugre y amenazados por un desplome inminente, donde Cuca "va en busca de sombra, pero casi todos los portales están en ruinas, y el sol se cuela por la obturación hecha a causa de un inesperado derrumbe de columnas" (197). 
Sus monumentales avenidas son transitadas de vez en cuando por lentos y destartalados automóviles que tuvieron sus días de gloria cuarenta años atrás. Al igual que Cuca Martínez, la maltratada ciudad de La Habana es una superviviente entre las carencias que cada día se intensifican, donde sus habitantes "sentados en el muro del Malecón, se achicharran al ardiente sol del eterno verano, miles y miles de espectadores semejantes a Cuquita, medio desfallecidos a causa del hambre, de la sed y el calor" (198). La Habana, anteriormente mitificada, a partir del capítulo cuarto es narrada con crudo realismo.

El argumento de Te di la vida entera, aunque en ocasiones utiliza la primera persona en su relato, se articula hasta el tercer capítulo a través de una narradora en tercera persona que afirma transcribir, en un estado de trance, la historia que le dicta el cadáver de María Regla, hija de la protagonista, Cuca Martínez, nacida en el año treinta y cuatro en la provincia de Las Villas. Cuca dedica la vida entera a un amor fracasado, el Uan, que a la vez es una metáfora del sueño de la Revolución cubana: "En fin, que así fue, y esa es mi vida. Toda una vida...Vida que he dado entera. Porque había que defender el sueño revolucionario" (107). La protagonista es un personaje alegórico que en la expectativa del regreso de su amado 
--una especie de Ulises caribeño que emigra a Nueva York en el año del triunfo de la Revolución--sufre una doble decepción: la separación de su marido y la hecatombe de la utopía cubana.

La novela está estructurada de forma que a partir del capítulo cuatro se advierte un cambio radical en la situación política del país, anunciada en el epígrafe que lo encabeza: "Se acabó la diversión, llegó el Comandante, y mandó a parar" (97). La escritora se vale de este recurso para iniciar el discurso deconstructor que pone en la voz de Cuca quien monologa sobre lo que será su obsesión cotidiana: "TRES DÉCADAS Y PICO SENTADA EN UN SILLÓN, haciéndome todas las noches la misma pregunta. ¿Qué haré de comer mañana?" (97). Suspendida en la añoranza de mejoría, en la expectativa que permite resistir las penurias diarias, Cuca vive con la cotidiana ilusión de un cambio en su país, al mismo tiempo que anhela reunirse finalmente con el hombre que ama. La expectativa de Cuca es también la del cubano suspendido en la añoranza de mejoría que le permite resistir las privaciones diarias. El regreso del protagonista masculino surge finalmente al cabo de treinta y seis años, casualmente durante el precario "período especial", cuando el discurso político de la Revolución ya ni siquiera ofrece una utopía, sino un 
inminente apocalipsis. La decadencia económica de la desvencijada ciudad que encuentra el Uan a su regreso está estrechamente vinculada con la decrépita Cuca--personaje alegórico de Cuba al igual que la Habana-- que por falta de alimentos tiene las "encías que ya tienen ampollas, más que callos, de tanto morder en el vacío" (250). De esta manera, el cuerpo de la protagonista se integra a la fisonomía de los espacios de la ciudad.

Es importante resaltar el papel protagónico del lenguaje en esta novela, que en ciertas instancias exhibe rasgos naturalistas. Si en La nada cotidiana se subvierte el rol femenino para desestabilizar las instancias del poder, en Te di la vida entera el lenguaje subvierte el discurso grandilocuente oficialista y el lema "patria o muerte, venceremos" con un contradiscurso deconstruccionista. Valdés articula un discurso político-literario digresivo con la intención de hacer ciertas interpolaciones en las que vierte sus reflexiones críticas. La novela no sólo muestra una intertextualidad desbordante, sino que también se presenta a sí misma como un producto de este fenómeno, en tanto que es un texto compuesto e influido por letreros, consignas, lemas, canciones, otros textos, etc. En la novela se insertan elementos metaficticios, tales como extensas recetas de cocina; que son una referencia 
directa a la Habana del paladar y la comida de antaño, inexistente ahora y sólo recreada en la memoria. De igual forma, con la intención de reforzar los códigos de la cultura popular, se insertan fragmentos de boleros populares que sirven de epígrafes introductorios en cada capítulo. ${ }^{14}$ Valdés aporta a la novelística cubana un nuevo decir a través de un choteo desmesurado plagado de juegos verbales que no perdona a nada ni a nadie. ${ }^{15}$ Por momentos, abandona la ficción narrativa y asume su voz de autora para hacer cuestionamientos sobre problemas de la realidad contemporánea cubana: "¿Vivimos para desarrollarnos o para subdesarrollarnos? ¿Las conquistas humanas se miden por el grado de pobreza, o por el grado de desarrollo? ¿Pobreza es sinónimo de dignidad?" (331).

Como señala Nelly Richards, la experiencia del mundo que verbaliza el lenguaje depende del órden semántico que moldea esa experiencia en función de un determinado patrón real y social (734). Cuca, la protagonista, presenta un testimonio fiel a su entorno social, reflejando así el proceso histórico que tanto la ha marcado: "¿Cómo se dice período especial en francés? Quescases. ¿Y en portugués? La resingasao nacional ¿Y en chino? Te toca un tin. ¿Y en japonés? T'o quita'o ¿Y en árabe? Barba embaraja la jama" (102). Este chiste lingüístico, basado en la deformación 
fónica de algunas palabras y frases del argot callejero cubano, incorpora un léxico subestándar al texto: "jama" significa comida; "singasao" proviene del verbo "singar", denominación vulgar para referirse al acto sexual; "embarajar" significa robarse algo ilícitamente; y Barba se refiere a uno de los muchos apodos de Fidel Castro.

El uso de este vocabulario alude directamente al "período especial", donde los personajes de la novela parecen gritar a cada instante: "Quescases" (iQué escasez!). El lenguaje de esta cita, dado el énfasis que se pone en lo oral, se caracteriza por el predominio del sonido por encima del significante. Valdés desencadena una auténtica destrucción del lenguaje, sirviéndose de unas técnicas que tienen como fin, tanto la ruptura del sistema semántico, como la desintegración del sistema fónico. La sola aproximación fónica arroja una violencia tonal que privilegia los sonidos agudos y llanos ("resingasao", "quita'o", "t'o", "embaraja", "jama"), acento tributario de la ascendencia fonética de la cultura africana, siendo hoy, sin embargo, más bien un indicador del discurso social que de reverencia para con el legado étnico. ${ }^{16}$ Es un lenguaje escrito que conserva el ritmo y las calidades de la lengua hablada. Dadas estas condiciones, no se puede acusar el lenguaje de traicionar la realidad o aun el significado, 
pues es fiel sólo a sus propios orígenes, al código lingüístico y cualquier "significado" que produzca se encontrará en relación de los significantes.

Las invenciones verbales y malabarismos lingüísticos que se observan a lo largo de $T e$ di la vida entera existen en virtud del mundo que crea la novela, ya que los registros sociales o políticos provienen de la fibra misma de ella. Esto nos remite al crítico Emir Rodríguez Monegal, que ya en su día advirtió, al referirse a Tres Tristes Tigres, que esa novela reflejaba "el lenguaje de una determinada zona de la sociedad cubana en una época determinada" ("Estructura" 117). Por su parte, Valdés se acoge a una formación léxica iniciada a raíz del "período especial", sobre todo aquellas palabras relacionadas con el dólar, moneda adoptada por el gobierno castrista y que el cubano actual ha rebautizado de mil maneras: "drácula, fula, juanikiki" (162). En Te di la vida entera, un elusivo dólar que el Uan le deja a Cuca antes de marcharse para los Estados Unidos, y volverá a buscar desesperadamente a su retorno, desencadena parte de la trama, a la vez que presenta un simbolismo plurisémico por las múltiples posibilidades metafóricas que crea en la novela. La moneda extranjera, tan necesaria para la supervivencia en un país regido por la escasez, constituye también uno de los 
elementos detonadores de la prostitución en el ámbito social cubano de los noventa, fenómeno al que se alude constantemente en La nada cotidiana y en Te di la vida entera.

El discurso de Valdés mezcla el subgénero del folletín a ritmo de bolero con juegos de palabras al estilo de Cabrera Infante. A veces innova o crea neologismos por vía de la derivación que encierran una significación doble. ${ }^{17}$ Así, emplea innumerable juegos de palabras como "dólar y dolor" para satirizar la situación económica del país; "comandante en jefe" y "comediante en jefe" para burlarse de Fidel Castro; "amnesia y anestesia", "edén y desdén" para parodiar la utopía castrista.

Hay que considerar la importancia que el humor como rasgo psicológico y caracterizador ha tenido y tiene en Cuba, hasta el punto de establecerse como uno de los elementos que ha dado origen a numerosos análisis sobre la identidad cubana. Uno de los estudios capitales es Indagación al choteo (1925) del crítico y etnólogo Jorge Mañach, quien consideraba que el humor es un rasgo idiosincrático del cubano:

Al par que uno de los grandes padecimientos del cubano, la burla crónica ha sido una de sus grandes defensas. Le ha servido de amortiguador 
para los choques de la adversidad; de muelle para resistir las presiones políticas demasiado gravosas [...] En otras palabras, ha sido entre nosotros un descongestionador eficacísimo. Como su operación consiste en rebajar la importancia de las cosas, el choteo surge en toda situación en que el espíritu criollo se ve amargado por una autoridad falsa o poco flexible.(85)

Para Mañach la burla es una actitud para afirmar la propia individualidad contra otra superior o poderosa y posee también una función crítica. ${ }^{18}$ De igual modo, en Valdés el choteo, íntimamente sitiado por el erotismo, es un arma que utiliza para atacar el discurso oficial a nivel cultural, social y político. Esta apología del choteo en todos sus matices es un elemento subversivo utilizado de forma recurrente por la escritora cubana, y también es su sello personal. En la narrativa valdesiana la ironía se vuelve sarcasmo y el humorismo llega a extremos de humor negro. De la misma manera, los elementos escatológicos quedan frecuentemente ligados a lo sexual, alcanzando en ocasiones el paroxismo.

Como se argumentó en el segundo capítulo, la novelista pone en primer plano los registros carnavalescos bajtinianos 
en su escritura al utilizar con el mismo desenfado e intención desjerarquizadora, tanto los códigos populares como las referencias de la llamada alta cultura. En ciertos momentos el lenguaje soez se desplaza a lo poético, intercalando su propia voz o citando a otros escritores como son los versos de Beatriz de Jústiz y Zayas, marquesa de Santa Ana, escritos en 1972:

¿Tú Habana capitulada?

¿tú en llanto?, ¿tú exterminio?

¿Tú ya en extraño dominio?

¿Qué dolor! ¡Oh Patria amada! (Te di 362)

Al insertar esta imagen poética en la última página de Te di la vida entera es evidente que la autora se hace eco del dolor que sintió en su momento Beatriz de Jústiz y Zayas al ver a su patria bajo la dominación inglesa, identificándose, al igual que la marquesa, con la faz trágica y lacerada de la historia de Cuba. Zoé Valdés, en su afán iconoclasta de romper con el discurso oficial cubano de "socialismo o muerte" (350), nos muestra también su dolor y el de la nación cubana sin que esto limite el potencial trasgresor de su alegato cuestionador.

La narrativa de La nada cotidiana y Te di la vida entera, se apoyan en el protagonismo colectivo estructurado en varios procesos agenciales, movidos por las tensiones 
socioeconómicas y la conflictividad política. Sus críticas y denuncias no están formuladas desde la victimación sino que muy por el contrario son contadas con rabiosa lucidez y una franqueza total que hace esa realidad aun más inquietante. Valdés se lanza en ambos textos a la más profunda y necesaria reflexión de su circunstancia histórica desde una perspectiva que le es propia a la literatura: la necesidad del enjuiciamiento crítico de la realidad, la intención de testimoniar la cotidianeidad y la vocación participativa del escritor.

Como el derrumbe de la vivienda de María Regla que ocurre al final de Te di la vida entera, costándole la vida a la hija de Cuca --personaje metonímico de la Revolución-, de igual modo Valdés establece en su novela que el régimen de Cuba está condenado al colapso, como todos los regímenes dictatoriales. Aun cuando este sistema gubernamental ha intentado en vano imponer sus dogmas y consignas, encaminados a la perpetuación del poder y contrario a la libertad humana, está condenado irremediablemente al fracaso. Es por eso que el verdadero compromiso de Valdés, más allá de la especificadas vindicaciones personales y denuncias del signo feminista que hemos detectado en sus novelas, está en plasmar los fracasos de la Revolución. La incapacidad del discurso revolucionario para captar a las 
nuevas generaciones educadas y adoctrinadas dentro de los estrechos ámbitos de su ideología caduca y esquematizada. La narrativa valdesiana desde perspectivas antes inéditas, analiza, enjuicia y refleja los lados más oscuros de la sociedad cubana posrevolucionaria. En sus novelas, el modelo utópico creado por el hombre nuevo guevarista se malogró; quedando sólo como ejemplo una sociedad decadente y maltrecha. 
1 El término "boom cubano" está emparentado con el "boom latinoamericano" creado por editoriales de Barcelona tales como Planeta, Anagrama y Tusquets en un intento por recrear el éxito editorial del fenómeno literario de los años sesenta, donde Seix Barral tuvo un gran protagonismo en la publicación de la nueva novela latinoamericana. Dos escritores cubanos publicados por estas editoriales, aparte de Zoé Valdés, son Daína Chaviano (Planeta), exiliada en Miami, y Pedro Juan Gutiérrez (Anagrama), residente en Cuba. Este término también aparece utilizado ampliamente en numerosos artículos críticos y en la prensa a partir de finales de los noventa. Por ejemplo, Rubén Cortés, en un artículo titulado "La buena salud de las letras cubanas" (1997) publicado por el periódico Crónica de México, afirma: "luego de cuatro décadas publicando dentro y casi exclusivamente para la isla, los escritores cubanos asaltan las librerías de España y América Latina para destapar un Boom de la literatura cubana". Otros ejemplos son "El nuevo boom de la narrativa cubana en España" de Raúl Cremades y Angel Esteban; "Cuban Novel Boom" de Omar Perdomo publicado en la edición en inglés del diario cubano El Granma; "La explosión literaria de la Habana" escrito por Amelia Castilla y Mauricio Vicente, publicado en el periódico español El País.

2 El "periodo especial", como se señala en el primer capítulo, fue el eufemismo oficial utilizado por el régimen castrista para calificar la peor crisis económica cubana a raíz de la desintegración del bloque comunista y la pérdida de los subsidios aportados por la Unión Soviética hacia Cuba.

3 En una entrevista concedida a la revista electrónica Contacto Magazine, Zóe Valdés se refiere al nuevo "boom" de la literatura cubana de esta manera:

Lo digo, y no me arrepiento. La nada cotidiana impulsó a muchos editores, españoles sobre todo, a buscar escritores cubanos, y yo también anuncié en la prensa del mundo entero un boom de la literatura cubana, algo que está sucediendo. Y de lo cual me alegro, pero no me alegro cuando ni siquiera mencionan esa novela aquéllos que viviendo en Cuba, e incluso en el exilio, han sido publicados gracias a las ventas de 
mi novela. Siempre me he cuidado mucho del ego, pero en ciertos momentos es imposible, sobre todo cuando tú has luchado mucho, y te quieren poner a un lado, en el montón. Nunca fui de grupo en Cuba, tampoco fuera, pero jamás del montón. (Hernández Cuéllar)

${ }^{4}$ Campuzano es catedrática de la Universidad de la Habana, directora de la revista Revolución y Cultura, y del Programa de Estudios de la Mujer en Casa de las Américas.

${ }^{5}$ En este sentido, Campuzano en una entrevista con María Grant publicada en Opus Habana, reitera cómo, paradójicamente, a pesar de las grandes movilizaciones por los derechos civiles, por los derechos de las mujeres, la guerra en Viet Nam. Todo lo que se produce en los años sesenta como consecuencia en gran medida de la Revolución cubana, en Cuba no hubo narrativa de mujeres, ni tematización de las mujeres, a pesar que las cubanas tenían condiciones sociales y politicas muy superiores a las que existían en cualquier otro lugar. (19)

${ }^{6}$ Hay que señalar que el rechazo a la crítica en general, y especialmente a la crítica feminista se debió en parte al control e influencia de Vilma Espín, esposa de Raúl Castro y presidenta fundadora de la Federación de Mujeres Cubanas. Ruth Behar en su estudio "The Erotics of Power and Cuba's Revolutionary Children" corrobora este control. La cita es larga, pero vale la pena añadir esta información:

The national desire to transform gender relations was serious, radical, and wide-ranging. But "feminism" as a term and concept remained unacceptable in a society where the women's movement was subordinate to the revolution. Espin has repeatedly said that the FMC is a "feminine" and not a "feminist" organization: an organization of women committed to a revolution that already speaks in their name. She has roundly declared: "We hate the feminist movement in the United States ...which conceived struggles of equality of women against men!...That is absurd! It doesn't make any sense! For these feminists to say that they are revolutionaries is ridiculous! ... That's what's most tragic. They're just being manipulated, being used. The feminist movement! Ha! You even see 
lesbians in their movement. Our work is to make everyone advanced. Then when everyone has a high consciousness, nobody will have to think in terms of equality." Espin's horror that the North American women's movement includes lesbians, as well as her disdain for the idea of gender egalitarianism, suggests that some women may have found it in their interest to collude in institutionalizing male heterosexual state power. As a critical observer puts it, Espín leads "a mass movement of women who construct their social-sexual identity and libidinal body from the perspective of the heterosexual male referential. (141)

7 Para más información véase Nara Araújo, "Proyección y perfil de la crítica feminista del Caribe", en Rita Teresinha Schmidt, org., Mulheres e literatura. (Tans) Formando identidades, 1997, (14).

${ }^{8}$ A finales del 2000, Campuzano le pidió a Catherine Davies que les hablara en Casa de las Américas acerca de cómo escribió A place in the Sun? Women Writers in Twentieth-Century Cuba, poco después la crítica cubana publicó en la revista Revolución y Cultura el texto de su conferencia. Según Campuzano, entre todas las dificultades que Davis debió salvar para acometer la tarea que se había propuesto, le faltó, entre muchas ausencias, para establecer un mínimo contexto de producción a partir del cual abordar ese siglo de literatura de mujeres "la Historia con mayúscula desde el punto de vista de las mujeres. Y [...] sobre todo, una historia de la política cultural y la cultura política de la mujer". (Davies, "¿Cómo escribir" 32).

9 Nara Araújo cita a pie de página en su artículo "Zonas de contacto: narradoras en la Isla y en la diáspora" publicado en la revista Temas de enero-marzo de 2003, una larga lista de las publicaciones en Cuba donde se incluían textos de escritores y escritoras de "dentro y de afuera". Por su importancia transcribimos la nota 25 del texto de Araújo:

En 1993, Ambrosio Fornet inicia en La Gaceta de Cuba la publicación de textos de la diáspora, una selección de los cuales reúne en Memorias recobradas...; en el 
año 2001, publica «La diáspora cubana y sus contextos (Glosario)» (Casa de las Américas, n. 22, La Habana, enero-marzo de 2001, pp. 22-9). En 1994, aparece en Madrid La poesía de las dos orillas. Cuba (1929-1993) (León de la Hoz, comp., Ediciones Libertarias), y en 1993, la antología de cuentos El submarino amarillo (Leonardo Padura, comp., UNAM, México, DF). Víctor Fowler publica en 1996, «Miradas a la identidad en la literatura de la diáspora» (Temas, n. 6, abril-junio de 1996, pp. 122-32). Por otra parte, Sonia RiveraValdés gana en 1997 el Premio extraordinario de literatura hispana en los Estados Unidos, de Casa de las Américas, con el libro de cuentos Las historias prohibidas de Marta Veneranda (Casa de las Américas, La Habana, 1998); al siguiente año, Lourdes Tomás Fernández de Castro el de ensayo artístico-literario con Espacio sin fronteras (Casa de las Américas, La Habana, 1999), y Jesús Barquet, el Premio Lourdes Casal de Crítica Literaria de la UNEAC con Escrituras poéticas de una nación: Dulce María Loynaz, Juana Rosa Pita y Carlota Caufield (Ediciones Unión, La Habana, 1999). En 2001, se edita por Letras Cubanas, Como un mensajero tuyo de Mayra Montero; y en 2002, de Mireya Robles, Hagiografía de Narcisa la Bella y de René Vázquez Díaz, La isla del cundiamor. En La Gaceta de Cuba han aparecido textos de Roberto González

Echevarría, Lourdes Casal, Gustavo Pérez-Firmat, Oscar Hijuelos, Eliana Rivero, José Kozer, Jesús Barquet, Emilio Bejel, Cristina García, Lourdes Gil, Uva de Aragón, Lilian Manzor, Elías M. Muñoz, Mayra Montero, Mireya Robles, Omar Torres, Antonio Vera-León, Carlos Victoria, Achy Obejas. En 1995, Ruth Bejar publica una selección de autores de dentro y de fuera, Bridges to Cuba, y en 2001, Iván de la Nuez reunió en un volumen de ensayos, Cuba y el día después (Mondadori, Barcelona), a escritores nacidos después de los 60, de la Isla y de la diáspora, entre ellos Víctor Fowler y Ena Lucía Portela, así como Rolando Sánchez Mejías y Emilio Ichikawa. En Todas las islas la isla. Nuevas y novísimas tendencias en la literatura y la cultura en Cuba (Frankfurt y Madrid, 2000), Janett Reinstädler y Ottmar Ette, reúnen ensayos sobre la literatura dentro y fuera de la Isla.

10 Neologismo surgido durante el "período especial" para referirse a la mujer que ejerce la prostitución. 
11 En su entrevista con Enrico Mario Santi, Valdés afirma que sintió no trabajar más a estos personajes, "pero así salió la novela y así se quedó" (11). Sin embargo, como señala Madeline Cámara, se nota su elaborada presentación de estas vidas paralelas mediante el recurrir a sus voces propias, usando el recurso de insertar sus respectivos recuentos en forma de cartas o conversaciones telefónicas (75).

12 El exilio geográfico entronca con la tradición de escritores cubanos desde principios del siglo XIX, tales como Cirilo Villaverde, José Martí y Heredia. También es preciso señalar a las escritoras Mercedes de Santa Cruz y Montalvo (La Condesa de Merlín)--que escribió desde Francia, pero siempre con una mirada retrospectiva hacia Cuba--y Gertrudis Gómez de Avellaneda. Esta última escribió dos de sus obras más famosas en España: Sab una novela que criticaba la esclavitud africana en Cuba y Dos mujeres. Ambas novelas escritas en 1844 fueron prohibidas en la Cuba colonial por contener temas controversiales como el racismo y la discriminación del indio y del negro.

13 Antes de Reinaldo Arenas, tanto la temática homosexual como el lenguaje descarnado fueron desdeñados por Lezama Lima y Virgilio Piñera, quienes utilizaban en sus novelas y poemas símiles oscuros y metáforas herméticas.

${ }^{14}$ Las canciones de donde proceden los epígrafes a los capítulos son las siguientes: 1. Be careful, it's my heart (Bola de Nieve); 2. Camarera del amor (Beny Moré) también de aquí procede el título de la novela-; 3 . Una rosa de Francia (Barbarito Díez); 4. Se acabó la diversión (Carlos Puebla); 5. Un cubano en Nueva York (Trío Oriental); 6. Lamento cubano (Guillermo Portabales); 7. Una cita de amor (La Freddy); 8. Miénteme (Olga Guillot);9. Con mil desengaños (La Lupe); 10 . Perdóname, conciencia (Moraima Secada); 11. Nostalgia habanera (Celia Cruz).

${ }^{15}$ Para una explicación más amplia a nivel semántico y etimológico del vocablo "choteo" consultar Indagación al choteo de Jorge Mañach. 
16 Para más información sobre los códigos lingüísticos cubanos véase El habla popular de hoy de Argelio

Santiesteban y De lo popular y lo vulgar en el habla cubana de Carlos Paz Pérez.

17 Es importante señalar que los juegos de palabras en Te di la vida entera tienen la intencionalidad de conectarlos con la realidad social del pais, mientras que en Tres tristes tigres se utilizan más bien para alejar el texto de la realidad social.

18 Gustavo Pérez Firmat argumenta en "Riddles of the Sphincter: Another look at the Cuban choteo" que Mañach omitió en Indagación del choteo los elementos escatológicos y obscenos que son crucialmente inherentes del choteo. 


\section{IA AGRESIÓN DISCURSIVA Y VINDICATORIA EN JUAN GOYTISOLO}

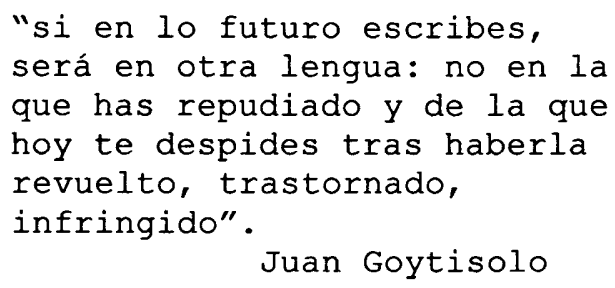

Señas de identidad (1966), Reivindicación del conde don Julián (1970) y Juan sin tierra (1975) configuran la trilogía de Juan Goytisolo denominada "España sagrada", conocida también como "Del desarraigo y de la ruptura". ${ }^{1}$ Su trilogía nace de un mismo tema nuclear--la deconstrucción y recodificación del lenguaje hegemónico-- el cual actúa como gozne unificador en las tres novelas. Las vivencias del franquismo y todo el proceso que éste desencadenó en el autor a nivel personal están siempre, de forma implícita o explícita, presentes en su escritura. Se trata de una obra profundamente inmersa en la situación española de la posguerra que proyecta un rechazo absoluto a las ideas y los valores trasmitidos por la ideología oficial. La tan proclamada ruptura goytisoliana con España responde a la traumática experiencia que tanto la Guerra Civil como posteriormente el franquismo ejerció en los escritores de su generación. Estas vivencias se materializan en una acuciadora pasión vindicatoria impulsada por un lenguaje que intenta destruir los mitos, valores e instituciones 
que desde la Reconquista al franquismo son sustentados por la nación española, constituyendo el núcleo en torno al cual el novelista estructura no sólo la trilogía "Del desarraigo y la ruptura", sino todo su corpus textual.

A partir de Señas de identidad, la novelística de Goytisolo se caracteriza por la fusión entre narrador y autor, rasgo que continuará en Reivindicación y Juan sin tierra. En Señas de identidad, un narrador inicia una inspección en el pasado, y la conciencia de Álvaro, quien en un largo relato interroga al recuerdo para encontrar sus "señas de identidad". La aproximación a la intimidad de Álvaro Mendiola a través de la segunda persona del singular logra el contrapunto entre el "yo" del protagonista y el "otro yo" del autor, en íntimo diálogo de confesión y de reproche que sirve para superponer recuerdos, reflexiones y angustias. Es una segunda persona narrativa y expositiva que nos adentra en el alma ambigua y desgarrada del protagonista como también es, en ciertas instancias, una dialéctica existencial entre autor y personaje:

Pese a tus esfuerzos de síntesis los diversos elementos de la historia se descomponían como los colores de un rayo luminoso refractado en un prisma $y$, en virtud de un extraño desdoblamiento, asistías a su desfile ocioso simultáneamente como 
actor y como testigo, espectador, cómplice y protagonista a la vez del remoto y obsesionante drama. (116)

A través de una alteración del presente y rememoraciones del pasado familiar y personal, el protagonista de Señas de identidad intenta encontrar sus raíces y reconstruir la vinculación con su país y su cultura. ${ }^{2}$ Pero Álvaro no logra dibujarse concretamente, es un ente que oscila entre la confesión autobiográfica y la ficción, en un perpetuo desdoblamiento que se observa también en las otras dos novelas de la trilogía. ${ }^{3}$ El desdoblamiento yo/tú podría corresponder al producido interiormente en Goytisolo, en una especie de autoanálisis que, al ser reflejado en la escritura, adquiere tonos de ejercicio exorcista, de purificación. El protagonista de Señas de identidad reaparece más tarde en Reivindicación como personaje cambiante que asume de forma progresiva las figuras de Séneca, Julián, Álvaro Peranzules, Alvarito y otros más, remedo todos ellos del propio Goytisolo. En Reivindicación, el empleo exclusivo del "tú" en casi toda la novela establece el desdoblamiento del narrador anónimo que se ve y se habla como si fuera otro, en un diálogo acusatorio donde él mismo es el personaje "emisor y receptor".4 
El "yo" goytisoliano que se cuestionaba incesantemente en Señas de identidad, en Reivindicación y Juan sin tierra, está dotado de una voz proteica que juega con los signos sin que "el lector ingenuo lo advierta: sumergiéndole en un mundo fluyente, sometido a un proceso continuo de destrucción" (Juan sin 146). El escritor utiliza el recurso de intercambiar las voces narrativas para permitirle al narrador asumir diferentes máscaras en una especie de carnaval bajtiniano, y convertirlo de esta forma en una entidad libre de toda restricción. Por esta razón, Goytisolo llama a los pronombres "yo/tú" pronombres apersonales "moldes substantivos vacíos" (Juan 146). El protagonista, consciente del recurso lingüístico que utiliza, nos dice:

La sintonía general que emitís propicia el escamoteo sutil fuera de la comunicación ordinaria: quién se expresa en yo/tú: Ebeh, Foucault, Anselm Turmeda, Cavafis, Lawrence of Arabia?: mudan las sombras errantes en vuestra imprescindible horma huera, y hábilmente podrás jugar con lo signos sin que el lector ingenuo lo advierta: sumergiéndole en un mundo fluyente, sometido a un proceso continuo de destrucción. (Juan 147) 
En Reivindicación y Juan sin tierra Goytisolo crea unos personajes que surgen, se transforman y desaparecen a voluntad del narrador. Estas "entradas" y "salidas" son las intervenciones en estas novelas de Álvaro Mendiola, de don Julián y del mismo Goytisolo. La crítica coincide con esta opinión, citada entre otros por Pere Gimferrer quien estima que el protagonista "se asemeja a un desfile de disfraces de transformismo que, bajo diversas caracterizaciones, nos ofreciera un solo actor" (18). Es evidente que el autor se propone en su narrativa destruir el concepto de personaje tradicional y suplantarlo por una figura simbólica múltiple. Estas metamorfosis que se operan en estas dos novelas de la trilogía a nivel de personajes, pueden interpretarse como una búsqueda por parte del protagonista de la clave que le defina y le haga comprender la sociedad que tanto critica; que le ayude a encontrar las señas de identidad que tan desesperadamente buscaba en la primera novela de su trilogía. Esta laberíntica superposición del personaje ha sido interpretada por algunos críticos como "la prolongación del mismo novelista convertido en fábula" (Ortega 152).

Toda novela presupone un emisor que no se puede identificar con el escritor real, pues ni siquiera en los relatos autobiográficos el autor logra involucrar su realidad completa y cotidiana; su voz pertenece a un alter 
ego (el narrador), en el que se personifican las circunstancias de producción del mensaje. Sobre la representación del escritor y el lector en las ficciones, Hubier señala que el lector de una novela, de un poema o una autobiografía, nunca está en relación directa con el autor, que es el verdadero sujeto del texto; y no puede responder jamás a éste, ni a la instancia que dentro del texto lo representa, el narrador. En todo caso, el texto literario no es más que una pseudo-enunciación que, irremediablemente, corrompe las reglas del intercambio lingüístico sobre las que se apoya, juega con ellas y las desvía para su provecho (23). De igual modo, en todo monólogo la focalización es interna: la residencia de la percepción coincide con un personaje que es el sujeto ficticio de todas las percepciones. Pero la instancia narrativa que se hace cargo del relato puede en cualquier momento variar. Los pensamientos y las palabras del personaje focalizador pueden estar directamente citados --lo cual es un monólogo traído-- o al contrario encontrarse revelados por un narrador que no pertenece a la historia y que tiende a la omnisciencia, lo cual es un monólogo narrativizado. En cuanto a la técnica de mezclar la tercera persona con las otras voces prenominales, como ocurre en la trilogía goytisoliana, se trata "de rendre la 
vie intérieur d'un personage en respectant sa langue propre, tout en conservant la référence à la première personne ainsi que le temps de la narration" (Cohn 122). Según Hubier, "la tercera persona puede ser considerada como una máscara tras la que se refugia un 'yo' bastante indeciso para presentarse inmediatamente al lector" (105), lo cual crea cierta ambigüedad, como ocurre en Señas de Identidad.

Roland Barthes muestra en S/Z, que la posibilidad de definir la ficción como una mímesis no es solamente porque ella busca imitar la realidad y hacerse pasar por verdadera sino también, y sobre todo, porque le gusta renovar continuamente los códigos (61). Esto indica, entre muchas cosas, que si la literatura de ficción puede ser metaliteraria, es porque imita otras formas, y comprende los géneros estrictamente referenciales, como por ejemplo los biográficos. Sobre el aspecto autobiográfico de la obra goytisoliana inciden muchos críticos que acuden a los datos suministrados por el propio autor sobre su vida para descubrir los herméticos eslabones entre él y su psique. Así apunta Navajas: "rotas las reservas objetivistas, Goytisolo vierte de lleno su personalidad en la novela" (163). Compartimos esta opinión, ya que, como hemos observado en esta tesis, el novelista es un producto de sus 
fantasmas, de sus circunstancias históricas, de todo lo que él vierte en sus novelas, que es también el bagaje constitutivo de su carácter personal. ${ }^{5}$ Sólo si se tiene presente la importancia del subconsciente del autor en su escritura, se está en un camino más acertado para una mejor interpretación de la obra. Ese constante diálogo entre el escritor y sus circunstancias es importante a la hora de interpretar el mundo enigmático y vengativo del protagonista goytisoliano, como también el vasto plan de destrucción y desmitificación que se proyecta en Reivindicación y Juan sin tierra. Por eso es importante señalar que:

The key to Goytisolo's writing is that the soul and the psyche are inextricably interwoven with both his aesthetic and political-socio-economic pronouncements and that the autobiographical and recreated elements of his novels are therapeutic in nature, an abreaction to bring repressed material to the conscious level so that through its examination the author may relieve the tension continuing subconscious conflicts. (Schwarts "Ambivalent" 188)

En conjunto, Goytisolo vuelca en la trilogía sus obsesiones y traumas, reflejando el proceso de introversión 
de un personaje en lucha por su liberación personal. Porque, como ha indicado el mismo autor, en el proceso creativo la vertiente más o menos irracional e individualista de un creador no puede ser cambiada de un golpe para convertirse en un ente puramente racional y objetivo. 6 Goytisolo ha expresado que la subjetivad, las neurosis personales, gustos, antipatías, intereses y preferencias reflejados en su obra son imposibles de escamotear, ya que: "dicha situación es absurda, y al obligado psicoanálisis de la obra del escritor debería agregarse, como materia de reflexión, el psicoanálisis de la obra del crítico" (Libertad 82). De igual modo, Kessel Swchartz llega a la misma conclusión diciendo: "Goytisolo's novel, a constant dialogue between himself and his circumstances, combines the commonplace with neurotic status and fantasies which promote a Freudian interpretation" ("Cultural" 962).

Freud descubrió los mecanismos de funcionamiento psíquico que son utilizados tanto en la creación literaria como en el sueño. El novelista moderno tiende, según él, a separar 'su 'Yo' en 'yos' parciales, lo que le lleva a personificar mediante diversos héroes las corrientes que chocan en su vida psíquica [...] cuando un creador utiliza temas literarios, su personalidad se manifiesta en la 
elección de los motivos que le hace sufrir" (Guimón 36). Asimismo, vemos cómo en Señas de identidad la confesión en tono de autorreproche continuamente se ve atrapada entre dilemas contradictorios, complejos de culpabilidad, y una inseguridad ontológica que jamás se resuelve en medio de un "yo" dividido:

La cabeza te dolía, el cuerpo te dolía y el espectáculo fantasmal de la sala común anticipaba a tus ojos la suerte que el destino justiciero te reservaba: morir lejos de tu país y de su huraña falange de súbditos, inmerso en el vasto caudal del sufrimiento humano, purgado equitativamente por las faltas de otros y también de las tuyas. (Señas 368)

Como ya se ha mencionado, uno de los procedimientos principales usados en Señas de identidad para proyectar el examen de conciencia de Mendiola consiste en una especie de monólogo interior, en donde Álvaro confunde imágenes del pasado con las del presente, que se insertan en el texto a través de documentos, recortes de prensa y fotos. Mediante este procedimiento, Goytisolo no solamente revela el proceso creador de la novela, sino que también abre el camino para Reivindicación del conde don Julián y Juan sin tierra, novelas donde el discurso se funde totalmente en 
una sola unidad sin transición, sin distinguir o indicar interpolaciones textuales extrínsecas. Asimismo, la disolución del lenguaje y de las formas narrativas tradicionales que comienza en Señas, sufre una innovación radical a partir de Reivindicación. En esta novela la prosa se fragmenta, los tiempos verbales se sustituyen por el predominante tiempo presente y la puntuación desaparece. Este drástico cambio en el arte de novelar, más que responder a las nuevas técnicas narrativas y la experimentación que estaba ocurriendo en el ámbito literario de la época, responde al desgarramiento y la rebeldía del narrador, "cuyos conflictos y dudas comienzan a manifestarse de tal modo que la desintegración de la prosa viene a ser la representación estilística de la desintegración de su ser" (Gould Levine 98).

Ya en Señas de identidad la voz narrativa de Goytisolo subvierte las instancias del poder a través de Álvaro, de forma que éste, al cuestionarse sobre su identidad, se pregunta de igual modo: ¿qué es España? Este cuestionamiento se agudiza con la muerte de Ayuso, su antiguo profesor, quien es "cubierto de tierra, cemento y ladrillo bajo la custodia de ellos, cuerpo indefenso al fin, definitivamente entre sus manos" (105). Durante el entierro del profesor, Álvaro reflexiona sobre la memoria de un libre 
pensador relegado ahora a los "abismos del olvido". Esta situación le revela al protagonista que para no ser aniquilado por el sistema censurador español tiene que destruir el discurso oficial que lo define; dedicarse a una tarea activa mediante la que pueda desestabilizar sus postulados y estrategias. Al mismo tiempo, su experiencia con los exilados españoles que se reúnen en el café de Madame Berger en París, descritos como "una extraña fauna de crustáceos amparados en sus dogmas como guerreros medievales" (201), lo defraudan y enajenan aún más. Totalmente desilusionado, afirma con amargura que "si la sociedad española es intolerante, se debe ante todo al hecho de que hay un maniqueo oculto en el corazón de cada español" (288). De esta manera, al exponer el fracaso de la política de la oposición tanto en España como en el exilio, Goytisolo se cree portador de la única voz con el derecho de revindicar a un país del cual se siente distanciado irremediablemente: Tierra pobre aún, y profanada; exhausta y compartida; vieja de siglos, y todavía huérfana. Mírala, contémplala. Graba su imagen en tu retina. El amor que os unió sencillamente ha sido. ¿Culpa de ella o de ti? Las fotografías te bastan, y el recuerdo. Sol, montañas, mar, lagartos, piedra. ¿Nada más? Nada. Corrosivo 
dolor. Adiós para siempre adiós. Tu desvío te lleva por nuevos caminos. Lo sabes ya. Jamás hollarás su suelo. (205)

En Reivindicación del conde don Julián, segunda novela de la trilogía, se desata una ruptura en un afán de desmitificar a la "España sagrada" que da como resultado una reescritura de la historia española a nivel literario, político y cultural. Gould Levine, una de las mejores estudiosas de la obra goytisoliana, sostiene que Reivindicación del conde don Julián exige del lector unos conocimientos amplios de la tradición literaria ibérica, de los estereotipos castizos y de las diversas interpretaciones vertidas en torno a la historia de España. Estos conocimientos son importantes por la intencionalidad del autor de incluir como subtexto la realidad censurante del franquismo e interrelacionarla constantemente con la historia de la "España sagrada". La desmitificación goytisoliana es también un ataque hacia Franco, llamado en la novela "el Ubicuo", "dueño y señor de los carpetos" (195). Éste proclamó para su "cruzada" la salvaguardia de las esencias genuinas hispánicas, fijadas por las teorías manipuladas de muchos historiadores y críticos literarios que exaltaron el misticismo y el senequismo como expresión del espíritu de la casta hispánica. ${ }^{7}$ Esta realidad es 
explicada por el propio Goytisolo en los siguientes términos: "Reivindicar la traición de don Julián es impugnar varios siglos de historia hostil mediante la agresión vandálica a la palabra escrita por nuestros cronistas, poetas y narradores" (Disidencias 293). El autor manifiesta esta preocupación por la lengua y vaticina la destrucción que llevaría a cabo en Reivindicación del conde don Julián en las últimas páginas de Señas de identidad cuando exclama:

Oh patria mi nacimiento entre los tuyos y el hondo amor que sin pedirlo tú durante años obstinadamente te he ofrendado separémonos como buenos amigos puesto que aún es tiempo nada nos une ya sino tu bella lengua mancillada hoy por sofismas mentiras hipótesis angélicas aparentes verdades frases vacías como cáscaras huecas alambicados silogismos buenas palabras. (483) Esta cita no sólo ilustra el desarraigo del escritor hacia su patria, sino que contiene ya el germen destructor del lenguaje que se llevará a cabo en Reivindicación. Goytisolo se convierte en un mitoclasta al escribir una novela de ficción de la historia oficial y devolverle la voz silenciada a los intelectuales españoles de su época. El concepto de la historia es totalmente subvertido por el 
escritor, quien mediante la sátira y la parodia, trastoca clisés y mitos que el pensamiento conservador y católico español ha recreado y sustentado a lo largo de su Historia como son el culto religioso, el senequismo, los maestros del 98, el paisaje castellano, el caballero español y la lengua académica, entre otros.

El anónimo y proteico protagonista de Reivindicación, en un continuo y alucinador monólogo interior, se convierte en el más acérrimo iconoclasta de lo español. Esto se evidencia, especialmente, durante sus visitas a la biblioteca de Tánger donde el narrador desata un ataque campal hacia las figuras consagradas de la tradición literaria y a la literatura mística castellana, exclamando con intención aniquiladora: "cuatro siglos de castellana podredumbre te contemplan" (228). El ataque busca la desacralización de obras y autores arquetípicos de una visión esencialista y monolítica de la realidad de España. Mediante una diatriba contra la hegemonía, el protagonista arremete una demolición galopante contra el patrimonio literario español, parodiando desde los sacralizados textos místicos; el teatro del Siglo de Oro, con su concepto de honor y "exquisito drama de honor", hasta la muy castiza generación del 98 y otros escritores contemporáneos, dejando muy pocos autores en pie. ${ }^{8}$ Esos creadores 
consagrados que ejemplifican fielmente qué es la escritura española son ridiculizados por el lenguaje que tradicionalmente los enaltece y define:

el estilo es noble, la dicción perfecta, [...] esmaltan la aridez conceptual del tema con flores de retórica, amena y elegante: qué armonía, qué cadencia, qué ritmo, qué imágenes!: y en cada parte de la oración y en cada oración del periodo, qué elipsis, transiciones, giros!: que movimiento, pasión, entusiasmo!(246)

Ese mito del "buen decir" castellano es destruido desde sus mismas raíces por haber servido de vehículo de hipocresía e insolidaridad. Esta visión del lenguaje es también una crítica a la Real Academia de la Lengua y su pretendida uniformidad y pureza lingüística. De ahí la importancia que el lenguaje cobra en la novela, y el intento por parte del autor de desmitificar la versión generalizada que se ha mantenido como representativa o definidora de la esencia española. La traición a la patria la lleva a cabo a través del único puente que le une a ella: la lengua española, la cual es desnaturalizada dislocando y retorciendo su sintaxis. Para subvertir aún más el lenguaje, el protagonista hace referencia a la revalorización de numerosos vocablos hispanos de etimología 
arábiga, utilizándolos como un modo de reivindicar el elemento árabe, integrante de la cultura española. ${ }^{9}$ También existe un acuciante interés en rechazar el lenguaje castizo e internacionalizarlo por medio de la inclusión en las tres novelas de fragmentos escritos en francés, inglés, catalán, y el español hablado en Cuba y otros países latinoamericanos. En la última novela de la trilogía, Juan sin tierra, la lengua española es diluida totalmente en el árabe. Esta transformación lingüistica con que termina el texto representa la liberación total del protagonista; convirtiendo ese abandono de la lengua materna, a partir de ese momento, en su seña de identidad.

En Reivindicación, el ataque y crítica hacia la literatura del Siglo de Oro y la generación del 98 existen en relación con lo que sus autores tienen de ideología y de lenguaje muertos. Para el narrador, los dioses literarios enaltecidos y canonizados son cómplices en la función tergiversadora de la realidad al proponer un "sentido ascético y militar de la vida" y ser "portadores de valores eternos". 10 Uno de los ejemplos más significativos del "textocidio" en Reivindicación es el que va dirigido hacia los maestros del 98, "que plasmaron en inmortales páginas de estilo sedeño, sentencioso, reposado, con una especie de grave ternura que se diría que le sale de los 
tuétanos iCastilla, Castilla!"(182). Esa Castilla "mística y guerrera", "Castilla gentil, humilde y brava" "cuna de héroes, forja de mártires, crisol de santos" que ha plasmado la literatura española (244), como también el mito del caballero cristiano que aparece infinitamente en novelas y poemas son desmitificados y parodiados por ser imágenes emblemáticas del régimen franquista y conceptos claves en la retórica de la Falange (Gould Levine 152).

En el tercer capítulo el narrador busca en la biblioteca el "decálogo del perfecto caballero cristiano" valiéndose de la obra del "esclarecido grupo de dramaturgos y profetas milagrosamente surgidos en vuestra tierra, allá en los confines del año de la gracia del 1898"(228). En su búsqueda, halla el domicilio del perfecto caballero cristiano. Séneca reaparece encarnado en la figura de Don Álvaro Peranzules. Éste, en sus múltiples encarnaciones, se convierte en un fantoche caricaturesco al personificar el prototípico morador del paisaje castellano, el carpeto, español ideal y perfecto caballero cristiano. Este esperpéntico personaje, que aparece totalmente identificado con el jefe de Estado y la doctrina falangista, es descrito como una especie de robot que se mueve trabajosamente: Haciendo crujir las distintas piezas de su armadura ósea, mezcla híbrida de mamífero y 
guerreo medieval: [...] a veces, la pose hierática y la elegancia del vestido lo asocian a un maniquí de madera: don Álvaro luce para ti, con empaque, el genio propio de su figura y la figura propia de su genio y, bruscamente, endurece aún más los rasgos petrificados de su mascarón y recita con voz pedregosa un soneto crustáceo, de morfología ósea y sintaxis calcárea, extraído de algún florilegio de fósiles. (231)

La dureza y rigidez que se observan en la descripción de Don Álvaro es también constitutiva, según se expresa en la novela, de la anquilosada literatura del Siglo de Oro. De los dramaturgos Calderón de la Barca, Tirso de Molina y Lope de Vega, como también de los escritores del $98 .{ }^{11}$ El Figurón, como también es llamado Don Álvaro, con su figura hipertrófica busca la confirmación de sus principios morales en los textos clásicos de la literatura española, mientras que el narrador trata de negársela a cada paso. Cada vez que este personaje lee en un libro uno de sus pasajes favoritos, un insecto le intercede el paso, bien porque el insecto se encuentra espachurrado en la página o porque sale volando. Estos accidentes ilógicos son recursos utilizados por el escritor para poner en marcha su 
máquina destructiva: páginas de libros que resumen el espíritu nacional-católico son profanadas por las sustancias viscosas de los insectos muertos. Éstos son descritos en términos científicos como "el díptero e himenóptero desastre" que se convierte en "fúnebre y renovado botín" para la traición-agresión de retóricas y conceptos encerrados en los textos seleccionados. En medio de las moscas que vuelan en denso enjambre, Don Álvaro exclama: "a mí, romancero, auto sacramental, libro de caballería!: Cid Campeador, Manolete, Meseta!: mística, tauromaquia, estoicismo!: Séneca! Séneca, Séneca" (249). Ahogado por el zumbido de la plaga que devora el papel escrito, Álvaro se va deteriorando paulatinamente. Las continuas interrupciones se hacen insoportables y las articulaciones dermato-esqueléticas de su coraza se deshacen hasta que finalmente le causan la muerte al ejemplar carpeto.

La destrucción de Álvaro Peranzules representa la aniquilación del mito del paisaje castellano y la raza de hombres que lo originaron. Como ya hemos mencionado, en Reivindicación el "tú" tiene como referente a varios personajes, y esto amplia sus posibilidades significativas. Cada uno de los diversos referentes del "tú" se diluye en una igualación a los otros; las diferentes encarnaciones y 
reencarnaciones sucesivas de Álvaro dentro de una misma novela nos lo prueba. Álvaro, Alvarito, Séneca junior y Séneca el grande son un mismo personaje, símbolo del espíritu carpetovetónico. Éstos confluyen en la narración para representar la forma de pensar y de sentir del personaje innominado (alter ego del escritor) que es todos ellos a la vez, y al mismo tiempo es el conde legendario que hace suya la traición donjulianesca. De igual modo que Álvaro Peranzules es destruido, el acto de violación sadomasoquista perpetrado hacia Alvarito y la muerte de éste, es a nivel simbólico, la aniquilación de la infancia y la adolescencia del protagonista de Señas de identidad. En la primera novela el personaje del niño, foco de los males adultos, es descrito con aborrecimiento porque representaba el sometimiento a las exigencias constrictivas de la España franquista. El Alvarito que reaparece en Reivindicación es el mismo personaje, mentalizado con los dramas de honor, las esencias hispánicas, descrito como una "figura impermeable y hermética" de "dureza granítica" (187). De ahí, por el valor alegórico de este personaje, los deseos por parte de Don Julián de vejarlo y destruirlo. El suicidio del niño significa el aniquilamiento de la parte negativa de la oposición, símbolo de la España 
sagrada, y la recuperación por parte del personaje narrador de su verdadera personalidad.

La postura crítica y denunciadora reflejada en la escritura de Goytisolo es una liberación de sus propias angustias y una forma de expulsar las autorrepresiones que lo acosan. En su búsqueda continua de la identidad personal, el autor imbrica también la identidad nacional. Como ha señalado Sobejano, Goytisolo es el primer escritor que logra dar una confesión exhaustiva y reveladora del conjunto social español, "que intenta definir la estructura de la sociedad desde la personal y la estructura de la conciencia personal desde el contexto social" (Novela 378). Reivindicación representa la superación definitiva de la novela española condenada desde la década de los cincuenta a cumplir el papel de denuncia de la realidad social que la dictadura y la censura le había negado a la prensa. Como indica José María Izquierdo, Goytisolo logra darle voz a todos esos silenciados por el régimen franquista:

The Spain of Franco's dictatorship generated a system of social and political "subnormality" founded on the coexistence of a quasi-theocratic political system in which General Franco governed by the "Grace of God" based on his peculiar ideological conglomerate: National Catholicism 
[...] Many voices silenced by the regime were raised against this phenomenon of "abnormality", and perhaps it was that of Juan Goytisolo among all of them that was best able to create a deconstructive model to erase the nucleus, not only of traditional spanish thought, but, of something more important, its symbolic model of representation. (154)

Es importante precisar, como ya se analizó anteriormente, que a partir de Reivindicación surge en la trilogía goytisoliana una disolución de las categorías narrativas tradicionales (autor, narrador, personaje, lector, así como el tiempo y el espacio de la novela), dando como resultado un texto eminentemente polifónico. En Reivindicación y Juan sin tierra es clara la intensiva intertextualidad utilizada por el autor en ambas novelas. En la primera, éste se vale de toda la tradición hispánica, a la que declara su "agradecimiento" en la advertencia final de la obra, para incluir en la novela la presencia de autores como Alfonso X el Sabio, Góngora, los dramaturgos del Siglo de Oro, los noventayochistas, etc. A estos textos se imbrican otros textos literarios, periodísticos, culturales, históricos; formando la totalidad de la obra 
narrativa. El resultado es una intertextualidad definida por Kristeva de esta manera:

Nous appellerons intertextualité cette inter-action textuelle que se produit a l'interior d'un seul texte. Pour le sujet connaisant l'intertextualité est una notion qui sera l'indice de la façon dont un texte lit l'histoire et s'insere en elle. La mode concret de realisation de l'intertextualité dans un texte precis donnera la caracteristique majeure ("sociale", "ethetique") d'une structure textuelle. (61)

Gracias al empleo de la intertextualidad, el narrador puede desentenderse de la organización de la novela que se nos presenta como un palimpsesto espacial y temporal. Este recurso lingüístico es el causante de la disolución de las categorías narrativas al enmarcarlas todas dentro de un juego literario en que toda realidad extrínseca deja de existir para convertir al texto en la única realidad posible, como señala Schwartz:

The novel, hovering between dream and reality and involving mythology and metaphysical doubts as it recreates the absurd in Spanish tradition, serves as a solipsistic atempt to prove that only 
Goytisolo's modifications and states are true existence. In its grotesque vision of the world, this work combines essay and literary criticism, viewing reality through strange symbols and structures and utilizing free association, dream, reverie, and double personality. ("Cultural" 960)

En Reivindicación los recursos ficcionales son inseparables del discurso crítico que apunta hacia la subversión lingüística e histórica con intención desmitificadora. La ficción reflexiona sobre otra realidad ya existente: aquella del discurso histórico. La novela procede a la descomposición de la Historia en una serie de hitos conectados libremente por el escritor para establecer los nexos entre el pasado y el presente. A través de juegos lingüísticos, fragmentación del tiempo y estrategias textuales se reforma y reconstruye el referente histórico. Reivindicación, como muchas de las nuevas novelas históricas, huye de la visión totalizadora para fragmentarse y adentrarse en el reino de las microhistorias. En este sentido, como ya se analizó en el segundo capítulo, adopta características bajtinianas por su ambigüedad y pluralidad. El autor nos lleva por los recovecos de una novela que se define por la conjugación de los más diversos temas relacionados con la historiografía española, 
desarrollándose dentro de lo ilógico e irracional. 'Por medio de este sistema, el texto funciona como una renarrativización donde existe un amasijo de los más disímiles elementos que le permiten al creador/destructor desbordar los cauces de su imaginación. Este demiurgo narrador incluso logra metamorfosearse en el conde don Julián--conocido también por el nombre de Ulbán o Bulián--, el mayor traidor de la historiografía española y culpable de la invasión árabe de la Península en 711 por Tariq. ${ }^{12}$

El traidor, en una fantasía "invasora" expresa su radical pretensión de destruir España: el territorio, la historia, la familia, las instituciones, todo. En su mente planea la traición que le obsesiona y lleva a cabo una fantástica invasión, violación y aniquilación total de aquella tierra que lo había expulsado de su seno. Esa invasión tiene por objetivo aniquilar todos los mitos y símbolos, que según él, han venido oprimiéndola secularmente: la religión tradicional, la virginidad femenina, el paisaje castellano y la propia lengua, sometida también a ese poder destructor. Por medio de la reescritura de textos históricos y literarios, el autor se propone hacer desaparecer la falseada e impuesta imagen de su propio país. La reivindicación que propone Goytisolo es de una violencia ideológica y estética, con un cúmulo de 
implicaciones psicopatológicas y sexuales, como indica

\section{Ramos :}

Hay en el protagonista un ardiente deseo de borrar el pasado, analizando todos aquellos elementos culturales que le impidieron realizarse de la manera que deseaba en su adolescencia. Alienado, por tanto, de la historia, el protagonista rompe violentamente con ella y la desplaza por el mito, proceso que requiere el quebrantamiento de toda la mitología que se considera falsa y a la vez reemplazarla por aquélla que se estima correcta. (162)

Como se ha analizado anteriormente, Goytisolo le otorga al narrador anónimo de Reivindicación una plasticidad que le permite moldearlo y ubicarlo dentro de la ficción a su manera para añadirle múltiples dimensiones a la narración. La novela está concebida como una parodia abierta que adquiere características del carnaval bajtiniano. Las categorías se anulan y las jerarquías se disuelven; lo religioso se degrada; lo bajo y vil--las violaciones de Don Julián--se elevan. La lógica es burlada y la locura reina debido a la fragmentación del tiempo del único día narrado. En un despliegue carnavalesco, una plétora de imágenes grotescas provenientes de diferentes 
épocas desfilan por la voz que monologa: Manolete, Séneca, Isabel la Católica, Los Reyes Magos, el Ubicuo, Cristóbal Colón, James Bond, etc. El autor satiriza radicalmente la identidad católica: la Semana Santa se transforma en carnaval, la Virgen en muñeca, las beatas en ninfómanas y el niño Jesús en mesías musulmán.

Estos hechos son narrados de manera cruda y grosera, buscando chocar al lector al presentar una liberación no solamente de las cadenas de la religión católica, sino también de sus propias raíces cristianas destruidas metafóricamente a través de la violencia del lenguaje. De igual modo, el delirante monólogo de Reivindicación emplea contextos insólitos para ubicar ciertos personajes históricos a través del valor metafórico que contienen los originales. Por ejemplo, Isabel la Católica aparece en varias instancias transformada en una mulata bailadora, en otras aparece como madre del Ubicuo o hija de Álvaro Peranzules, siendo finalmente violada por los árabes del ejército de don Julián. A través de estas transformaciones Goytisolo no solamente destruye a Isabel la Católica, "sino también la madre del 'Ubicuo', a Fernán González y la doctrina falangista" (Gould Levine 194).

Isabel la Católica, por medio de una relación sinecdóquica, es el arquetipo de la España conservadora y 
sexualmente reprimida. Dentro de esta tendencia mitificadora que cobra el espacio geográfico, la península ibérica alcanza un alto nivel de jerarquización que Goytisolo intenta socavar y denunciar en la necesidad de rebasar sus propias represiones. Las constantes alusiones despreciativas al entorno ibérico muestran la especial relación de amor-odio entre el protagonista-narrador y la madre-patria. La restricción como forma de frustración se dispara contra la simbólica España y sus mitos, sobre todo la religión católica, contra la cual el autor ciñe un ataque sin tregua con el fin de emanciparse de las represiones que lo definen como parte de la cultura española. La obsesión sexual de Julián está ligada a la obstinada defensa que el católico español ha hecho a través de los siglos del principio de castidad, como lo prueba "el haber sido declarado la Inmaculada Concepción dogma oficial en España e impuesto al catolicismo" (Ortega 114). ${ }^{13}$

Gran parte de Reivindicación está dedicada a la labor de desmitificar los símbolos de la religión católica, contra ellos Goytisolo deja caer toda su fuerza aniquiladora, recordándonos algunos filmes de Buñel tales como Viridiana y La vía lactea. Muchos estudios críticos han analizado esa aversión y visceral rechazo de ciertos creadores españoles hacia esta institución religiosa. 
Todos los críticos que examinan este tema, como ya hemos analizado en el primer capítulo, argumentan que los antecedentes se remontan a la época de la Reconquista que estableció la exaltación de la castidad, la austeridad y el espíritu religioso en virtudes nacionales. Estas cualidades pasaron a ser definitivamente parte de la Historia de España a lo largo de los siglos y definieron la idiosincrasia española, a diferencia de otros países de fuerte tradición católica, como Italia o Irlanda. Ortega insiste en el papel represor de la iglesia en la conformación de la mentalidad española:

A esta violencia patológica en defensa de ciertos principios que el católico español se asigna hay que unir, por lo que respecta al español, una de las características de la psique española: el orgullo. El exceso de estimación está intimamente relacionado con la atribución que el católico español hace de una verdad y la violenta custodia de ésta. Orgulloso, en su satisfacción por sus propias cualidades espirituales, se cree superior al otro, sentimiento hacia el contrario que se manifiesta generalmente mediante el padecimiento del prójimo. El orgullo es consecuencia del individualismo, o rechazo de 
toda norma, y la agresión que suele acompañar a éste (transformado ya en soberbia) se debe al repudio y renuncia del mundo de los instintos donde la ley natural encuentra plena satisfacción y donde puede descargarse la agresividad.(115-16) En el ensayo El malestar en la cultura, Freud sostiene que la especie humana ha pagado el elevado precio de sacrificar la vida instintiva y ha debido reprimir la espontaneidad en aras de los ideales e imperativos culturales. La sociedad, al igual que la religión, obstaculiza la felicidad personal porque la cultura reposa sobre la renuncia a las satisfacciones del instinto; "la libertad individual no es un bien de la cultura" (41). De esta forma, el objetivo de ambas instituciones es el de establecer una unidad formada por la comunidad en lugar de 10 individual, porque es más importante el objetivo de establecer una entidad formada por grupos humanos que la adquisición de la felicidad individual. Según Freud, la religión impone a todos por igual su camino único para alcanzar el bienestar $y$ evitar el sufrimiento:

Su técnica consiste en reducir el valor de la vida y en deformar delirantemente la imagen del mundo real, medidas que tienen por condición previa la intimidación de la inteligencia [...]el 
creyente, obligado a invocar en última instancia los "inescrutables designios" de Dios, confiesa con ello que en el sufrimiento sólo le queda la sumisión incondicional como último consuelo y fuente de goce. (Freud 30)

De acuerdo con Freud, la historia del hombre es la historia de la represión; pero tal represión es la condición esencial para el progreso. Es lo que él llama la transformación del principio del placer en el principio de la realidad. Tal ajustamiento del placer implica la subyugación de la gratificación instintiva. "Esta negativa produce una fijación, o sea que la representación de que se trate perdura inmutable a partir de ese momento, quedando el instinto ligado a ella" (Freud 167).

Las ideas expuestas por Freud en su psicoanálisis obviamente se evidencian en la trilogía goytisoliana que plantea en este sentido el retorno de lo reprimido en su forma más evidente del imperativo moral del catolicismo español. Desde la perspectiva de la represión freudiana "todos los elementos reprimidos, es decir, inconscientes, pertenecientes al mundo familiar, sexual, político y literario del autor-protagonista, hacen su aparición en Reivindicación bajo la forma de sueños, magia o neurosis" (Ortega 88). A partir de la segunda novela de la trilogía 
surge en el autor una acuciada pasión casi homicida de satisfacer sus deseos subconscientes de venganza. Es una agresión vandálica que llega a críticos como Saavedra afirmar que la novela es "una gran venganza alucinada [...] una obra insólita, agresiva, luciferina" (27). Goytisolo crea un precedente en la literatura española no solamente por la innovación narrativa que se percibe en su prosa, sino por la violencia textual donde se palpa un resentimiento brutal utilizado para denunciar su propia cultura. Posiblemente no exista en la literatura española otro ataque que se le pueda comparar por su desmitificación y dureza. Esto ha llevado a varios críticos a analizar los rasgos psicológicos del arquetipo goytisoliano, entre los más lúcidos se encuentra el de Gould Levine, quien afirma: El odio y el autodesprecio abarcan una larga trayectoria y corresponden a un sinnúmero de razones: sentimiento de culpabilidad hacia su propio fondo burgués, incapacidad de desarraigar totalmente de sí mismo sus últimos vestigios del orden español, frustración e impotencia por no poder realizarse dentro de la sociedad española. (137)

En la obra de Goytisolo, la manifestación del odio hacia el pasado y el deseo imprescindible de purgarse de 
él por la palabra escrita proporciona una dimensión psicológica contradictoria, generando una escritura que se mueve en el espacio de lo ambiguo, que como señala Kristeva es también abyección: "la abjection est surtout ambigüité. Parce que, tout en démarquant, elle ne détache pas radicalment le sujet de ce qui le menance" (Pouvoirs 17). El autor-narrador quiere renunciar a su país pero al mismo tiempo no puede desatarse de los lazos culturales que le unen a él; la España que quiere olvidar está presente en su literatura de una manera obsesionante. Esta resistencia de renunciar totalmente a sus raíces se manifiesta en la misma técnica de desdoblamiento utilizada a través de la trilogía. Fallecidos los deseos de destrucción en la novela anterior, el niño Alvarito reaparece en Juan sin tierra recordándonos que el autor se encuentra detrás del texto con su insistencia reiterativa del tema religioso. El carácter confesional en partes de la novela emerge de nuevo en las descripciones del carácter de este personaje, ejemplificador de la esmerada educación cristiana propia de "los infantes de su estirpe", Alvarito surge de nuevo en la narración: Manifestando desde su edad más temprana una profunda y encantadora devoción a los Misterios de nuestra religión revelada y en especial al de 
la Inmaculada Concepción de la Virgen: en vez de entregarse a los juegos inocentes y alegres de la niñez como sus restantes compañeros de colegio, prefería refugiarse en el oratorio privado de la familia y, al pie del altar, lejos del tráfago ciudadano y mundanal ruido, permanecía horas enteras de hinojos, absorto en meditaciones graves y abstrusas. (203)

Estos pasajes confesionales aparecen con la intención de explicar el cambio que se ha operado en la trayectoria de Álvaro-niño al Álvaro-adulto, destruido en las dos primeras novelas de la trilogía y ahora convertido en un apátrida sin pasado, transformado en el desterrado y errante Juan que emprende en esta novela una lucha liberadora desde la reivindicación corporal.

En Juan sin tierra se percibe que a pesar de los ataques anticlericales que el autor desata en su escritura, continúa influido y acosado por la religión que lo forjó. Esto se evidencia aún más al vincular la represión del cuerpo con la retórica del discurso católico español que promueve la sublimación del placer sexual como medio de alcanzar el reino de Dios. En Juan sin tierra Goytisolo continúa el discurso religioso presentándolo como una oposición entre la corrupción del cuerpo y la pureza de 
Dios. En las múltiples identidades del personaje Vosk, al hacer de capellán, refleja el orden y la autoridad del poder supremo, exponiendo el cuerpo como emblema del mal que necesita ser reprimido para seguir el ejemplo divino. La novela se inicia en la Cuba, donde la familia Mendiola vivía durante la época de la colonia. Agustín, el dueño del ingenio azucarero, es firme creyente de los dogmas de la religión propagados por el capellán, y se percibe como un ser que sólo por medio de la negación de su corporeidad puede participar de la divinidad. De igual modo, Vosk inculca estas ideas, con tonalidades de sermón eclesiástico, a los esclavos en la plantación de azúcar que siempre se han entregado a la satisfacción del apetito sexual:

Pues, hijitos, para que creéis que os han traído desde las selvas remotas de África sino para redimiros por el trabajo y enseñaros el recto camino de la salvación cristiana?: no os alarméis por las penalidades que os toca sufrir: esclavo será vuestro cuerpo: pero libre tenéis el alma para volar a la morada de los escogidos: por eso [...] os hicimos cruzar el agua salada: con grillos y cadenas, para que el demonio no os instigara a volver a una vida silvestre [...] al fin de que un día pudierais sentaros a la diestra 
del Padre, absortos en la dicha y visiones de mil visiones sublimes: con el alma blanca como el blanco superior del azúcar: el Amo del Ingenio de Arriba os mirará con semblante risueño y nadie os echará en cara la color prieta, el pelo pasudo, la nariz roma, los bembos bestiales [...]: la virgen Blanca os sentará a su mesa y os brindará con sus propios manjares: en lugar de desmedrar en la negrura infecta y sobrellevar eternamente sus taras, adelantaréis poco a poco en linaje espiritual y mejoraréis la calidad dañina y sombría de vuestras almas. (35)

La alusión al fuerte contraste entre lo claro y lo oscuro, a la pureza de lo blanco en oposición a lo negro se expresa a lo largo de la novela en una variedad de formas. Una de las manifestaciones más recurrentes de esta dicotomía es el contraste entre la suciedad y la limpieza. También se expresa en el primer capítulo mediante el contraste de la pureza celestial, ejemplificada por los amos blancos y la negritud de lo pecaminoso por los negros esclavos. Goytisolo subvierte esta imposición dogmática de la religión al invertir los códigos implantados e imponer su propia visión social. En uno de los pasajes, Vosk se dirige a los esclavos para persuadirlos de la necesidad de los actos de 
fe, pero el Deo Gratias no se lleva a cabo debido a que la cantante negra, La Reina del Ritmo que aparece en la carátula del disco que el narrador tiene en su cocina, se opone a la música insípida eclesiástica. En oposición al discurso religioso católico, el texto presenta la religión adulterada en la versión Yoruba de la Encarnación. Los cuerpos etéreos de las figuras religiosas son transformados en las sensuales carnes negras de la Reina del Ritmo, metáfora de la liberación del cuerpo en un sistema esclavizador.

En Juan sin tierra, Goytisolo imbrica la escritura del cuerpo con la escritura política en una verdadera exaltación del sexo como purga literaria y venganza última contra la sociedad. La persistente insistencia del código sexual prácticamente en cada una de las páginas de la novela, manifiesta sin lugar a dudas el intento por parte del escritor de resexualizar a España. Es evidente, como se ha discutido anteriormente, que el autor busca en la escritura satisfacer sus necesidades psicológicas. Si en Señas de identidad Álvaro Mendiola discretamente aludía a su ambigüedad sexual, en Juan sin tierra existe una clara resonancia homosexual. El estilo del lenguaje utilizado en esta novela está lleno de códigos sexuales y homoeróticos que alcanza el terreno de lo obsceno. Tal como señala 
Gould Levine, "el homosexualismo se vuelve sinónimo de la libertad; el instinto no es un impulso ciego: es la crítica hecha acto" (105). La sexualidad transgresora se convierte en una rebelión, constituyendo una provocación en un sistema totalitario y masculino por decreto.

En esta última novela de la trilogía, el planteamiento esencial es la necesidad de liberar al cuerpo considerado como entidad sublimada por los designios del Poder, y romper con las prohibiciones que éste le impone para que se ajuste a sus intereses morales e ideológicos. La sumisión a las reglas, la restricción de las relaciones sexuales a la esfera del matrimonio y sólo con fines reproductivos, así como la represión de los deseos, son reemplazados por el placer y la libertad: actividades que intentan corromper la ideología monolítica del sistema represor. Las actividades liberadoras que se expresan en Juan sin tierra se relacionan con las ideas de Octavio Paz en Conjunciones $y$ disyunciones. El libro de Paz alude a las relaciones de afinidad y oposición de dos signos: el signo "cuerpo" y el "signo no-cuerpo" en el mundo occidental, India y el Oriente. Paz indica que la oscilación entre los signos "cuerpo" y "no-cuerpo" a lo largo de la historia es el eje en torno al cual giran las concepciones religiosas y sociales, con sus dogmas e ideologías: 
En India y China la conjunción fue el modo de relación entre los signos cuerpo y no-cuerpo. En el Occidente, la disyunción. En su última fase, el cristianismo exagera la separación: condenación del cuerpo [...] En su fase última, el cristianismo engendra la sociedad arreligiosa moderna y desplaza la relación vertical entre los términos por la horizontal: el cielo se vuelve historia, futuro, progreso; y la naturaleza y el cuerpo, sin dejar de ser enemigos, cesan de ser objetos de condenación para convertirse en sujetos de conversión. (110)

Para Paz, la conexión entre el lenguaje y la sexualidad está relacionada en la antítesis del "cuerpo" y "no-cuerpo", un conflicto esencial para la comprensión del pensamiento y comportamiento del pensamiento indoeuropeo. Según Paz, las sociedades orientales han encontrado maneras de fusionar la dicotomía (conjunciones), mientras que el mundo occidental continuamente exagera la dualidad (disyunciones). Mientras que el amor físico fuera del matrimonio son pecaminosas para los cristianos, los budistas mantienen una fascinación sacramental hacia lo erótico. Aunque Octavio Paz expresa explícitamente que esta dicotomía no tiene otro significado que indicar una 
oposición diametral, los ejemplos utilizados para desarrollar este concepto (cuerpo en oposición al alma, lo racional contra lo irracional y la actividad sexual contra su condenación) sugieren la creencia en una libertad total del cuerpo humano y la futilidad de su represión. Esta creencia es también compartida por Goytisolo para quien el concepto de disyunción es válido en el contexto español, ya que la historia de España ofrece claros ejemplos de los postulados establecidos por Octavio Paz.

Goytisolo se hace eco en su obra del ocultamiento del cuerpo en la mentalidad católica. Como subraya Paz, "no hay religión sin referencias al cuerpo" (120). Por ello, a Goytisolo no le basta solamente desmitificar y parodiar la sociedad española, sino que alza subversivamente la novela frente a la mentalidad represora de la Iglesia. El rechazo patológico del cuerpo por las instituciones religiosas es un factor temático para el escritor, que se propone aniquilar y restaurar los mismos elementos que la casta cristiana ha eliminado: lo erótico y la exaltación de lo corporal.

En Juan sin tierra se arremete contra el concepto religioso-católico de negación del cuerpo y en contrapartida se proclama la exaltación jubilosa del placer carnal. El autor trata de instaurar por medio de la 
escritura un nuevo reino donde florezcan las pasiones y los deseos tenidos por nefandos y culpables: "si amor te solicita rebelde a toda norma, dale franca acogida, no le niegues el pan: premia la labor ciega del cuerpo" (Juan 135). Para lograr su cometido, Goytisolo ataca los fundamentos de la tradición religiosa y enaltece la cultura árabe donde "religión y erotismo no son términos antagónicos para el musulmán; su ley no le veda las satisfacciones del placer físico" (Disidencias 121). Para Goytisolo el Islam representó para España toda una cultura, desde la base lingüística del vocabulario castellano hasta el terreno del erotismo. La represión de la sensualidad hispanoárabe se debió, como indica Xavier Domingo, a que: El sentimiento y la sexualidad son para el árabe cosas indisolubles. Para el cristiano todo lo que concierne el sexo es nefasto y puede contaminar el alma. Aunque cristianos y musulmanes vivían en el mismo suelo, de manera casi idéntica, sus concepciones en materia tan esencial como el amor se oponían de modo tan rotundo que no es extraño que su guerra dure ocho siglos y termine con la aniquilación del vencido. Todo lo que el español lleve en sí de árabe es 
reprimido sin piedad, y en primer término la sexualidad. (53)

Esta represión es paralela al establecimiento de un orden dominante que utiliza una moral ideológica y religiosa con la intención de restringir los instintos, logrando que el cuerpo se someta a las necesidades del sistema. Los propósitos de Goytisolo responden al deseo de problematizar la represión perpetrada por un conjunto de fuerzas que confieren la tarea de defender "su Verdad". Como sostiene Barthes, todo sistema ideológico es una ficción y cada ficción posee un discurso propio "supported by a social jargon, a sociolect, with which it identifies [...] for each jargon (each fiction) fights for hegemony; if power is on its side, it spreads everywhere in the general and daily occurences of social life, it becomes doxa, nature" (The pleasure 27, 28). El lenguaje según Barthes no es ingenuo, ya que "language always comes from some place, it is a warrior topos" (28). Por ello Goytisolo se opone en su literatura a lo que condicione ideológica y sexualmente al individuo y propone un constradiscurso que cuestione todos aquellos valores y paradigmas impuestos por el discurso del Poder. Esto guarda gran paralelismo con la distinción establecida por Barthes entre "el placer del texto" y "la jouissance del texto": 
Text of pleasure: the text that contents, fills, grants euphoria; the text that comes from culture and does not break with it, is linked to a comfortable practice of reading. Text of bliss: the text that imposes a state of loss, the text that discomforts [...], unsettles the reader's historical, cultural, pshychological assumptions, the consistency of his tastes, values, memories, brings to a crisis his relation with language.

Mientras que "el placer del texto" no rompe con el sistema cultural e ideológico que lo ha producido, el texto de "jouissance" es de naturaleza subversiva, desestabiliza todo el sistema que lo ha originado. Por ello, Goytisolo, al no poder expresarse en el lenguaje establecido, crea un lenguaje desde su subjetividad como elemento estructurador de la obra, un lenguaje que exprese la inherente naturaleza erótica del acto de escribir. El autor presenta esta actitud hacia su propia escritura concebida estéticamente como función sexual. Su objetivo es buscar: "la secreta, guardianesca ecuación que soterradamente aúna sexualidad y escritura [...] empuñar la pluma y dejar escurrir su licor filiforme, prolongando indefinidamente el orgasmo" (239). En ciertas instancias el escritor interrumpe el discurso 
narrativo para recordarle al lector el intenso placer con que escribe su texto: "te entregas al experto onanismo de la escritura: el invertebrado, improductivo acto de empuñar la pluma y escurrir su filiforme secreción genitiva según las pulsiones de tu voluntad" (225).

Juan sin tierra ilustra la importancia del lenguaje y el protagonismo del mismo en la novela. A diferencia de las otras dos obras que componen la trilogía, donde existen escasos comentarios explicitos sobre el arte de narrar, en esta última abundan reflexiones sobre la escritura en general y el texto que se está escribiendo. El propósito no está en lo que se cuenta, está en el análisis del modo en que se organizan los elementos de la novela; del proceso estructurante del escribir, del discurso narrativo o escritura. Goytisolo crea un lenguaje fragmentado y discontinuo motivado por representar la realidad por otro camino que no sea el representacional, logrando expresar mediante la elaboración exhaustiva del lenguaje y el carácter proteico de su prosa, su vengativo discurso desmitificador. 
1 Véase José Corrales Egea, "Don Julián y la destrucción de España" y Gonzalo Sobejano, "Don Julián, iconoclasta de la literatura patria".

2 En entrevista con Emir Rodríguez Monegal, Goytisolo discute su intención creativa en Señas de identidad de esta forma:

Me he propuesto hacer un 'collage' de materiales sin fundirlos completamente en el cuerpo de la novela, he intentado evitar toda sistematización de una técnica determinada, toda formalización para salir de esta especie de 'impasse', de callejón en que los novelistas españoles nos sentimos encerrados. ("Destrucción" 53)

3 Es importante tener en cuenta la observación de Gould Levine en relación al aspecto psicológico en Señas de identidad donde en el primer capítulo Goytisolo, al presentar sus experiencias infantiles y de su adolescencia, deja una huella imprescindible en su desarrollo

psicológico. Esto puede presentar cierta contradicción con la teoría estética de esta obra, pues si por un lado Goytisolo busca crear en ella una narración radicalmente diferente de la novela del siglo XIX, donde el narrador presenta a personajes de corte psicológicos, por otro no puede renunciar a este elemento para caracterizar al protagonista. $(14,15)$

4 En "La novela española contemporánea" Goytisolo precisa que el autor es el "personaje emisor" mientras que el protagonista anónimo es el "personaje auditor receptor". (38).

5 Este aspecto también se señaló en el tercer capítulo, respecto a la escritora cubana Zoé Valdés,

6 Libertad, Libertad 82.

7 Este concepto de la historia fue patrocinado por Ramón Menéndez Pidal y Marcelino Menéndez Pelayo, entre otros.

8 Goytisolo, a pesar de que rechaza la imagen casticista de la tradición literaria española, sobrevalora 
a determinados autores de su predilección con los que se identifica y recupera en la novela, tales como Juan Ruíz y su obra Arcipreste de Hita, La Celestina de Fernando Rojas, Cervantes, Fray Luis, Góngora y las teorías históricas y literarias de Américo Castro.

9 Los vocablos árabes usados por Goytisolo tienen un precedente en la literatura medieval española. Partiendo de las propias palabras del autor en entrevista con Milagros Sánchez Arnosi:

El Arcipreste de Hita incluía bastantes palabras árabes en su obra literaria, si lo hacía él, no veo por qué no lo pueda hacer yo. [...] Es simplemente devolver a la cultura española algo que formó parte de ella y que por razones históricas dejó de serlo. Me parece que es un homenaje a uno de los ingredientes de la cultura española. (4)

10 Según Goytisolo, a partir de la Guerra Civil, los intelectuales que permanecieron en España se dedicaron a la "reactualización un tanto artificial de las figuras del 98" (El furgón 125). La protesta se dirige más hacia la relectura, que posteriormente hicieron otros, del análisis de la realidad de España llevada a cabo por los antes jóvenes del 98. Los intelectuales a los que hace referencia, se pusieron de espaldas al presente refugiándose en el estudio de lo que ya no era amenazante al régimen.

11 Unamuno y Menéndez Pidal vieron en Calderón y el tema de honor un símbolo de la casta eterna de España.

12 La reescritura de este hecho histórico que el autor propone se basa principalmente en la refutación de la mitificada historia, según aparece en los romances escogidos por Menéndez Pidal referidos al derrumbamiento de la monarquía visigoda, y concretamente los de don Rodrigo, el último rey godo. De igual forma, la leyenda se convierte en historia recogida en la Crónica general de Alfonso $X$ el Sabio y que después repetirán las sucesivas historias de España prácticamente de la misma manera. Goytisolo sigue las huellas de la interpretación histórica de Américo Castro al oponerse radicalmente a la 
historiografía oficial empeñada en glorificar el reino visigodo y disminuir la contribución árabe en la península.

13 Fue España quien impuso el dogma de la Inmaculada Concepción en la Iglesia Católica que ya Inocencio III, a principios del siglo XIII, había establecido como imagen idealizada de la iglesia. Debido a que los cátaros defendían el principio femenino de la idea platónica del amor y exaltaban el amor pasión, la Iglesia tuvo que poner otro ideal como indica Ortega citando a Denis de Rougemont:

In order to counter this powerful and almost universal rise of Love and of the cult of Idealized Woman, The Church and clergy were bound to set up a belief and a worship which met the same profound desire, as this sprang out of the communal spirit of the time. While the Church had to fall in with that desire, the Church had also to 'convert' it and lead it into the strong stream of orthodoxy [...] Which not prevent the Church of Rome, in the person of Pope Innocent III, who dreamed of the 'empire of the world' and could not stand the defection of Northern Italy and Languedoc, from launching in 1209 a Crusade against the Cathars -the first genocide or systematic massacre of a people recorded by our 'Christian' western history. (109) 


\section{CONCLUSIONES}

El objetivo de este estudio ha sido concretar una realidad textual que interrelacione la problemática del Poder con la escritura de Zoé Valdés y Juan Goytisolo. La obra de estos escritores está condicionada por unos paradigmas contextuales generados por una censura que los marcara psicológicamente y unos mecanismos que les han obligado a aceptar la ideología monolítica de sistemas dictatoriales. En ambos novelistas encontramos la utilización de un discurso deconstructor y recodificador que de no haber estado influido por las represivas realidades experimentadas en el contexto en que ambos se desarrollan, no se habría nutrido de tanta agresividad, o hubiese estado impelido por

el obsesivo deseo de vindicar circunstancias personales. La rebeldía y el clamor de estos escritores responden a una sola causa y a una sola verdad: la necesidad de libertad. Por lo tanto, son obras altamente contestatarias y comprometidas con su tiempo histórico, ya que responden a las circunstancias sociales y políticas de los sistemas gubernamentales donde se desarrollan.

Los principios que rigen a estos novelistas tienen su origen en el rechazo absoluto a las ideas y valores trasmitidos por los dogmatismos de regímenes totalitarios. 
Los textos de Goytisolo y Valdés enfrentan sus estrategias críticas de reinscripción discursiva sobre el poder omnímodo, constituyendo actos políticos subversivos en sí mismos. El primer capítulo nos conduce a una reflexión que permite percibir la diferencia entre la escritura de autores sujetos a la censura de países totalitarios con los surgidos dentro de sistemas donde existe la libertad de expresión. En un país totalitario, al intelectual se le coloca ante la elección de servir al poder o luchar en su contra. En los países en donde existe libertad expresiva el escritor rara vez actúa en respuesta a la opresión o la censura. Por consiguiente, el "inconsciente político" como refiere Jameson, especifica la articulación de aquellos condicionamientos con la sociedad en la que ocurre la expresión literaria.

En el segundo capítulo observamos que tanto a través de la praxis de los formalistas rusos como los postulados de Ferdinand de Saussure, las palabras no son los nombres de las cosas sino que forman una entidad autónoma, regida por sus propias leyes. En las obras de Goytisolo y Valdés, la deconstrucción en el lenguaje es un contradiscurso que apunta a la descentralización del poder hegemónico. Es decir, la deconstrucción constituye un arma para desjerarquizar la naturaleza controversial de todo centro, 
y específicamente en la óptica de nuestros escritores, para realizar un desmantelamiento radical de los mitos creados durante el franquismo y el castrismo respectivamente. La teoría derridiana, dado que se aleja del logocentrismo y nos permite aclarar las situaciones en cuyo marco las novelas estudiadas adquieren su pleno sentido, ya que la teoría deconstruccionista sugiere una lectura subversiva de los textos $y$ los discursos autoritarios.

Sin embargo, una lectura deconstruccionista igualmente nos mostraría que la nueva jerarquía--el contradiscurso de los escritores en cuestión--es también inestable, y puede entregarse al libre juego de los opuestos binarios. Otro aspecto a destacar, como señala Derrida, es que no hay nada fuera del texto. Todo en la vida es como un texto y éste no es más que un juego de diferencias. En este entorno, la argumentación se deconstruye a sí misma en los esquemas en que la construye su creador. Porque la deconstrucción, como afirma Todorov citando a Goodheart, "es un escepticismo dogmático, que posee los inconvenientes de ambos excesos" (228)

Por su parte, el tercer capítulo analiza el discurso de Zoé Valdés a la luz de la realidad de los textos teóricos feministas. El feminismo postestructuralista presenta discursos conflictivos donde el lenguaje asume un papel 
primordial: nos constituye como sujetos pensantes y permite darle significado al mundo para transformarlo. La postulación que sustenta la obra de Valdés es la de una recodificación radical del patriarcado a través de un lenguaje trasgresor en que se inscriben códigos sexuales subvertidos, construyendo a su vez un alegato vindicatorio. El discurso erótico valdesiano imbrica a la nación e intenta validar la resistencia al falocentrismo, transgrediendo los roles tradicionalmente asignados a la mujer. En esas circunstancias, se evidencia asimismo la intencionalidad de reivindicar a la mujer a través de la inscripción corporal

de la escritura como nuevo locus de enunciación en el texto. Esta realidad discursiva, aunque válida a la luz de las teorías postestructuralistas femenistas contemporáneas, las cuales asumen que la feminidad es incensurable y la sexualidad de la mujer es siempre transgresora, presenta una problemática insoluble: la jerarquización de la libido femenina. Aun cuando este discurso es capaz de quebrantar el orden simbólico masculino al inscribirse en un modelo paradigmático que une el texto a una vivencia de la sexualidad, proyecta a la mujer disminuida, transida por los deseos del varón que la reducen a los límites de su cuerpo. 
Finalmente, en el cuarto capítulo, analizamos el arte novelesco de Juan Goytisolo concentrándonos en el análisis de la fijación del lenguaje utilizado por el autor quien propende a disolver el relato de los acontecimientos y acciones en su propio discurso desmitificador. Este ha sido el propósito que ha guiado la ejecución de las novelas que componen la trilogía de la España sagrada: Señas de identidad, Reivindicación del conde don Julián y Juan sin tierra. En ellas el escritor barcelonés arremete contra el lenguaje castellanista heredado de los escritores del 98 y endosado por los escritores de su generación. Un lenguaje, según él, incapaz de filtrar ya, a través de su sintaxis calcificada, la complejidad del mundo moderno. Por ello, propone la total renovación del mismo para poder atacar la casta social que ocupa el poder y que emplea la misma retórica de anquilosamiento lingüístico.

Esta búsqueda por parte de Goytisolo de una nueva sintaxis se evidencia en Señas de identidad y se hace realidad en Reivindicación del conde don Julián, donde a través de un lenguaje drásticamente innovador destruye los más arraigados mitos ibéricos para recodificar la historiografía española de acuerdo a su propia perspectiva historicista de los hechos. 
Finalmente, Juan sin tierra, revela la proteica concepción de la escritura desarrollada en las otras dos novelas analizadas. El cuerpo como escritura y la escritura como cuerpo configura la textura de esta novela, la cual imbrica a su discurso corporal no sólo la trilogía goytisoliana, sino igualmente el binomio valdesiano. En la medida que condena, en nombre del signo "cuerpo", la ideología dogmática que oprime al individuo y reivindica la exuberancia sexual como único elemento humano irreductible a la cosificación. Desde esta perspectiva, los discursos de Juan Goytisolo y Zoé Valdés se entrelazan entre sí por la incorporación del signo cuerpo en la diégesis y las alusiones al sistema político que los tiraniza. 


\section{Bibliografía}

Alvarez, José. "Literatura cubana de los 80: una visión sin censura." Torre de Papel 3.3 (1993): 85-98.

Araújo, Nara. "Lo Cubano and the Literature of the Novísimas." Cuba, the Elusive Nation Interpretation of National Identity. Eds. Madeline Cámara y Damián J. Fernández. Gainsville: Florida UP, 2000. 224-39.

---. "Zonas de contacto: narradoras en la Isla y en la diáspora." Temas. No 32 (enero-marzo 2003): 48-58.

---. "Proyección y perfil de la crítica feminista del Caribe." Mulheres e literatura. Ed. Rita Teresina Schmidt. Porto Alegre: Universidade Federal do Rio Grande, 1997. 5-18

Arenas, Reinaldo. "El mar es siempre el símbolo fundamental de la liberación. (Conversación con Reinaldo Arenas)." La memoria frente al poder. Ed. Jacobo Machover. Zaragoza: Universitat de Valencia, 2001. 251-70.

Badía, Arnhilda. Ed. La educación en Cuba: Pasado, presente Y futuro. Miami: The Endowment for Cuban American Studies, 1993. 83-94.

Bajtín, Mijaíl M. Problemas literarios y estéticos. La Habana: Arte y Literatura, 1986.

Barthes, Roland. Mythologies. New York: Hill and Wang, 1972.

---. El placer del texto. México: Siglo XXI, 1974.

---. The pleasure of the Text. New York: Hill and Wang, 1975.

---. "Change the Object Itself." Image-Music-Text. New York: Hill and Wang, 1977.

---. S/Z. Essais. Paris, Seuil, 1976.

---. "Lingüística y literatura." Variaciones sobre la escritura. Barcelona: Paidós, 2002. 33-40.

--. "La linguística del discurso." Variaciones sobre la escritura. Barcelona: Paidós, 2002. 65-71. 
Behar, Ruth. "The Erotics of Power and Cuba's Revolutionary Children." Cuba, the Elusive Nation Interpretation of National Identity. Ed. Madeline Cámara y Damián J. Fernández. Gainsville: Florida UP, 2000. 134-54.

Cabrera Infante, Guillermo. Mea Cuba. Barcelona: Plaza y Janes, 1992.

---. Tres tristes tigres. Barcelona: Seix Barral, 1983.

---. Amanecer en el trópico. Barcelona: Plaza \& Janés, 1984.

Campuzano, Luisa. "Literatura de mujeres y cambio social: narradoras cubanas de hoy." Temas 32 (enero-marzo 2003): 38-47.

Castro Ruz, Fidel. "Palabras a los intelectuales". Política Cultural de la Revolución Cubana. Habana: Editorial de Ciencias Sociales, 1977. 5-47.

Cámara, Madeline. "Del barroco a la posmodernidad: parodia de la picaresca en La nada cotidiana de Zoé Valdés." La letra rebelde. Miami: Ediciones Universal, 2002. 57-83.

Castilla, Amelia y Mauricio Vicent. "La explosión literaria de la Habana." El País. (Cultura) (diciembre 29, 1997): 27

Cixous, Hélène. La risa de la medusa. Ensayos sobre la escritura. Barcelona: Anthropos, 1995.

Cohn, Dorrit. La Transparence intérieure. Modes de représentation de la vie psychique dans le roman. París: Seuil, 1981.

Corrales Egea, José. "Don Julián y la 'destrucción' de España." Cuadernos de Ruedo Ibérico 31-32 (1971): 97-101.

Cortés, Rubén. "La buena salud de las letras cubanas." Crónica, (México) 21 de febrero, 1998.

Cremades, Raúl y Esteban, Angel. "El nuevo boom de la narrativa cubana en España." Leer XVI, 113 (junio 2000): 48-51. 
Davis, Catherine. "¿Cómo escribir una historia de la Literatura de mujeres en Cuba? Algunas refexiones." Revolución y Cultura. (marzo-abril 2001) Suplemento Literario.

De Rougemont, Denis. Love in the Western World. New York: Pantheon Books, 1959.

Domingo, Xavier. Erótica hispánica. París: Ruedo Ibérico, 1969.

Eagleton, Terry. Una introducción a la teoría literaria. México: Fondo de Cultura Económica, 1988.

Escudero Rodríguez, Javier (Ed.). Cartas de Américo Castro a Juan Goytisolo. Valencia: Pre-Textos, 1997.

Espín Guillois, Vilma. Informes centrales de los congresos la FMC. La Habana:Imprenta Central de las FAR, 1990.

Fernández, Damián J. (Ed.) Bajtín, Mijaíl. Teoría y estética de la novela (Trabajos de investigación). Madrid: Taurus, 1989.

Foucault, Michel. La voluntad de saber. Madrid: Siglo XXI, 1976.

---. La vida de los hombres infames. Madrid: La Piqueta, 1990.

---. Las palabras y las cosas. Madrid: Siglo XXI, 1997.

French, Peter A. The virtues of Vengeance. Kansas: UP Kansas, 2001.

Freud, Sigmund. El malestar en la cultura. Madrid: Alianza, 1999 .

Fuentes, Carlos. La nueva novela hispanoamericana. México: Cuadernos de Joaquín Mortiz, 1969.

Gil-Toja, Herman. Reivindicación del conde don Julián de Juan Goytisolo ante la Crítica (1969-1986): Una revisión. Tesis Doctoral, RheinischenFriedrich Wilhems- Universität. Bon: 1989. 
Gimferrer, Pere. "El nuevo Juan Goytisolo." Revista de Occidente 137 (1974): 13-39.

Gimón José. Psicoanálisis y Literatura. Barcelona: Kairós, 1993.

Gomá y Tomás, Isidro. (Arzobispo de Toledo, Delegado Pontificio Castrense): "El concepto cristiano de la muerte y el heroísmo de nuestros combatientes." Boletín Oficial del Clero Castrense $n^{\circ} 5,31$ de Octubre 1937 .

Gómez Redondo, Fernando. La crítica literaria del siglo XX. Madrid: EDAF, 1996.

Gould Levine, Linda. Juan Goytisolo: la destrucción creadora. México: Joaquín Mortiz, 1976.

Goytisolo, Juan. Cogitus interruptus. Barcelona: Seix Barral, 1999.

--- Disidencias. Barcelona: Seix Barral, 1977.

--- El furgón de cola. Barcelona: Seix Barral, 1976.

--- En los reinos de Taifa. Madrid: Alianza, 1999.

--- Juan sin tierra. Barcelona: Seix Barral, 1975.

--- Reivindicación del Conde don Julián. Madrid: Cátedra, 1970.

---. Señas de identidad. México: Editorial Joaquín Motriz, 1966.

--- "La novela española contemporánea." Libre II (diciembre-febrero. 1971-2) :33-40.

---. Libertad, Libertad. Barcelona: Anagrama, 1978.

---. Pájaro que ensucia su propio nido. Barcelona: Galaxia Gutenberg, 2001.

--- Entrevista con José A. Hernández. Modern Languages Notes 41 (1976): 337-355. 
Grant, María. "Mujeres en línea con Luisa Campuzano." Opus Habana VI (Número 3 2002): 16-25.

Guevara, Ernesto. "El hombre y el socialismo en Cuba." Obra Revolucionaria. Selección y prólogo de Fernández Retamar. México: Ediciones ERA, 1979.

Guillermo, Edenia y Hernández, Juana A. La novelística española de los 60. New York: Eliseo Torres, 1970.

Guisáosla y Menéndez, Cardenal Arzobispo de Toledo. "El peligro del laicismo y los deberes de los católicos." Carta Pastoral. Barcelona: Acción Social Popular, 1915.

Hernández Cuéllar, Jesús. "La literatura es misterio y libertad. Entrevista con la autora de 'La nada cotidiana' y 'Te di la vida entera'." Contacto Magazine. (octubre 27 2001) URL (http: //www. contactomagazine.com/zoe100.htm

Hermet, Guy. Les catholiques dans l'Espagne franquiste (I). Les acteurs de jeu. Paris: Presse de la fondation nationale des sciences politiques, 1980.

Hubier, Sébastien. Littératures intimes. Les expressions du moi, de la autobiographie à l'autofiction. Paris: Armand Colin, VUEF, 2003.

Irigaray, Luce. Ese sexo que no es uno. Silvia Ester Tuber de Peyrou. Madrid: Saltés, 1981.

Izquierdo, José María. "Ideological Aspects in the Work of Juan Goytisolo." Readerly Writerly Texts. 5.1 \& 5.2 (Fall/Winter 1997 \& Spring Summer 1998): 147-70.

Jakobson, Roman. Selected Writings, Vol.III. The Hague: Mouton, 1981.

Jameson, Fredric. The Political Unconscious as a Socially Symbolic Act. New York: Cornell UP, 1988.

Jauss, Hans Robert. "Literary History as a Challenge to Literary Theory." Reader-Response Criticism: From Formalism to Post-Structuralism. Ed. Jane Tompkins. Baltimore: Johns Hopkins UP, 1981. 1198-1220 
Kristeva, Julia. Pouvoirs de I'horreur. Paris : Editions du Seuil, 1980.

--- Le langage, cet inconnu. Paris: Editions du Seuil, 1981.

---. "Problems de la structuration du texte." Linguistic et Litterature. París, La Nouvelle Critique, 1968.

Le Vagueresse, Emmanuel. Juan Goytisolo, Ecriture et Marginalité. Paris:L'Harmattan, 2000.

Llerena, Mario. Mito y espejismo de la revolución. Miami: Fundación Nacional Cubano Americana, 1995.

López Álvarez, Pablo y Jacobo Muñoz. La impaciencia de la libertad, Michel Foucault y lo político. Madrid: Biblioteca Nueva, 2000.

Mañach, Jorge. Indagación al choteo. Miami: Universal, 1991.

Morcillo, Aurora G. True Catholic Womanhood. Illinois: Illinois UP, 2000.

Navajas, Gonzalo. La novela de Juan Goytisolo. Madrid: Sociedad General de Librería, 1979.

Ortega, José. Juan Goytisolo-Alienación y agresión en Señas de Identidad y Reivindicación del Conde don Julián. New York: Eliseo Torres \& Sons, 1972.

Ortiz Ceberio, Cristina. "La narrativa de Zoé Valdés: hacia una recodifiguración de la na(rra)ción cubana." Chasqui 27.2 (1998): 116-27.

Palacios, Jesús. "Zoé Valdés: Ron y caña." Qué leer 2 (1996) : 58-59.

Payne, Stanley G. A History of Fascism, 1914-1945. Wisconsin: Wisconsin UP, 1995.

Paz Pérez, Carlos. De lo popular y lo vulgar en el habla Cubana. La Habana: Editorial de Ciencias Sociales, 1988 . 
Paz, Octavio. Conjunciones y disyunciones. México: Editorial Joaquín Mortiz, 1969.

Perdomo, Ornar. "Cuban Novel Boom." Granma International. Digital Edition, 3 de febrero, 1999. http://www. granma.cu/1999/íngles/ febrero 3/6feb11i.htm1

Pérez Firmat, Gustavo. "Riddles of the Sphincter: Another Look at The Cuban Choteo." Diacritics 14. (4) 1984: 65-77.

Picón-Salas, Mariano. De la conquista a la independencia. México: Fondo de cultura económica, 1982.

Poncio, Augusto. La revolución bajtiana. Madrid: Cátedra, 1998 .

Ramos, Alicia. "Defensa del erotismo en don Julián." Iris 3 (1982): 159-74.

Richards, Nelly. "Feminismo, experiencia y representación." Revista Iberoamericana LXII. (julio-diciembre 1996): 733-44.

Rodríguez Monegal, Emír. "Estructura y significaciones de Tres tristes tigres." Guillermo Cabrera Infante. Ed. Julio Ortega. Madrid: Editorial Fundamentos, 1974. 81-128.

---. "Destrucción de la España sagrada." Mundo Nuevo 12 (junio 1967): 44-60.

Rohter, Larry. "Living with a Shortage of Everything but Desire." New York Times (enero 7 1998): E2.

Ruíz Lagos, Manuel, (ed). Juan Goytisolo. Madrid: Ediciones de Cultura Hispánica, 1991.

Saavedra, Luis. "La estructura ilimitada de Juan Goytisolo." Cuadernos para el diálogo XXI (1971): 23-29.

Sánchez Arnosi, Milagros. "Entrevista con Juan Goytisolo. La creación literaria como Liberación." Insula 426 (mayo 1982) :4 
S/N. "Zoé Valdés." La Revista 55 (noviembre 3 1996) http://www.elmundo.es/magazine/num55/textos/zoe1.html

Santí, Enrico Mario. "La vida es un salmón con grasa: entrevista con Zoé Valdés." Apuntes posmodernos (Otoño 1998): 2-13.

Santiago, Fabiola. "Writer paints tales of life in Cuba with vivid stroke of experience." Miami Herald, 25 de mayo, 1997. 1I

Santiesteban, Argelio. El habla popular de Cuba hoy. La Habana: Editorial de Ciencias Sociales, 1985.

Schwartz, Kessel. "Juan Goytisolo: Ambivalent Artist in Search of his Soul." Journal of Spanish Studies: Twentieth Century 3 (1975): 187-197.

---."Juan Goytisolo, Cultural Constraints and the Historical Vindication of Count Julian." Hispania 54 (1971): 960-966.

Sobejano, Gonzalo. "Don Julián, iconoclasta de la literatura patria." Camp de L'arpa 43-44 (1977):7-14.

--- Novela española de nuestro tiempo: en busca del pueblo perdido. Madrid: Prensa española, 1975.

Tello, J.A. Ideología y Política. La Iglesia católica española (1936-1959). Zaragoza: Libros Pórtico, 1984.

Todorov, Tzvetan. El hombre desplazado. Madrid: Taurus, 1998.

--- Literatura y significación. Planeta: Barcelona, 1974.

Valdés, Zoé. Entrevista con Bárbara Cabana. Miami, noviembre 10, 2003. 1-6.

---. La nada cotidiana. Buenos Aires: Emecé, 1995.

---. Te di la vida entera. Barcelona: Planeta, 1996.

---."La ciudad reencontrada." El País. (diciembre 10, 1997) Cultura: 1-4. 
Vargas Llosa, La verdad de las mentiras. Barcelona: Seix Barral, 1990.

Wharhol, Robyn, ed. An Anthology of Literary Theory and Criticism. New Jersey: Rutgers UP, 1991. 
VITA

BARBARA CABANA

Born in Havana, Cuba

1983

B.A., Humanities, Minor in Art History

Florida International University

1987

M.A.,Hispanic Studies

Florida International University

$1988-1989$

Post-graduate courses in education

St. Thomas University and

Florida International University

1987-1997

Humanities and Art History teacher our Lady of Lourdes Academy, Miami

1997-present

PRESENTATIONS

Miami Dade Community College InterAmerican Campus

Adjunct Professor, ESL Dept.

F.I.U. Conference on World Cinema (January 28, 2002) The Influence on Baroque Painting in Erice's Cinema.

SCHOLARSHIPS

Dissertation Year Fellowship, 2003

AND AWARDS

Fellowship Endowment for the

Humanities, 1992. 